\title{
POLITÉCNICA
}

UNIVERSIDAD POLITÉCNICA DE MADRID

FACULTAD DE CIENCIAS DE LA ACTIVIDAD FÍSICA Y EL DEPORTE

\section{USE OF INFRARED THERMOGRAPHY AS A TOOL TO MONITOR SKIN TEMPERATURE ALONG THE RECOVERY PROCESS OF AN ANTERIOR CRUCIATE LIGAMENT SURGERY}

TESIS DOCTORAL INTERNACIONAL / INTERNATIONAL DOCTORAL THESIS

SERGIO PIÑONOSA CANO

LICENCIADO Y MÁSTER EN CIENCIAS DE LA ACTIVIDAD FÍSICA Y DEL DEPORTE

DIPLOMADO EN FISIOTERAPIA 



\title{
DEPARTAMENTO DE DEPORTES
}

FACULTAD DE CIENCIAS DE LA ACTIVIDAD FÍSICA Y DEL DEPORTE - INEF

\section{USE OF INFRARED THERMOGRAPHY AS A TOOL TO MONITOR SKIN TEMPERATURE ALONG THE RECOVERY PROCESS OF AN ANTERIOR CRUCIATE LIGAMENT SURGERY}

\author{
AUTOR: \\ SERGIO PIÑONOSA CANO \\ LICENCIADO Y MÁSTER EN CIENCIAS DE LA ACTIVIDAD FÍSICA Y DEL DEPORTE \\ DIPLOMADO EN FISIOTERAPIA
}

DIRECTORES:

DR. JAVIER SAMPEDRO MOLINUEVO

DR. MANUEL SILLERO QUINTANA 

"Life can only be understood backwards; but it must be lived forwards"

-Soren Kierkegaard- 


\section{AGRADECIMIENTOS}

A la Universidad Politécnica de Madrid y a la Facultad de Ciencias de la Actividad Física y del Deporte-INEF por su gestión envidiable a todos los niveles y por las ayudas económicas prestadas a lo largo de los cursos académicos como la Ayuda para la Realización del doctorado concedida en el año 2010.

Al Hospital Clínico de San Carlos y a todo su equipo de rehabilitadores y fisioterapeutas por permitirme y facilitarme las instalaciones y los pacientes para la consecución de este trabajo.

A mis directores Javier Sampedro y Manuel Sillero Quintana por estar siempre al pie del cañón, sobre todo en esta recta final que han empujado como el que más. A ellos les debo que esto haya sido posible.

Al tribunal de esta tesis que han tenido que cruzar media España o medio mundo para poder estar hoy aquí y compartir este momento tan importante. Gracias a todos.

Al Grupo de Innovación Educativa "Areté", encabezado por Teresa González Ajá y Vicente F. Gómez Encinas, que junto con Rodrigo Pardo, formaron parte de un momento de inflexión en mi vida en el que mi perspectiva sobre la profesión, el futuro, las personas y el modo de trabajar cambió por completo. A ellos les debo una enorme lección de vida que llevo conmigo desde entonces.

A mis compañeros y amigos del laboratorio por estar conmigo en cada momento y ayudarme sin reservas. A Ismael Fernández porque siempre le he visto como un ejemplo a seguir en su tenacidad y constancia en lo que se propone. A Miguel Ángel García por su buen corazón y su disposición incondicional a ayudar y trabajar en cualquier momento. A Pedro Gómez por brindarme la oportunidad de involucrarme en este proyecto conjunto y así aprender de su modo pausado de ver las cosas y su constancia con valor incalculable. $Y$ por supuesto a todas las personas que han rondado el laboratorio y la universidad haciéndolo más alegre y mejor; Javier Pinilla, María Peláez, Beatriz Maroto, Javier Arnáiz, Isabel Rossignoli, Javier Butragueño, Rocío Cupeiro, Yaiza Cordero, Guillermo Bryant...

A todos los profesores que han colaborado conmigo, tanto a nivel nacional como internacional, especialmente a Joao Carlo Bouzas y su familia, que me acogieron en su equipo y casa como uno más desde el principio.

He borrado y reescrito este párrafo varias veces. Este párrafo va dedicado a mi padre y mi madre. He pasado toda mi vida con ellos y aun así, me siento incapaz de encontrar unas palabras que hagan justicia a sus personas. Me siento orgulloso de ellos, de ser su hijo, por ser como son, por habernos educado como lo han hecho, por hacernos ver 
que los únicos límites que existen son los que uno se pone, por apoyarnos a mi hermana y a mi cada día que ha pasado. Parece mentira el poco tiempo que a veces tenemos para pararnos a pensar y reflexionar en estos detalles, que a fin de cuentas son los que más importan.

Los que bien me conocen, saben que soy persona de familia, por ello estas líneas van dirigidas a todos ellos, los que están y los que ya se fueron, sois un tesoro. Especial mención para mis tíos Gregorio y Alicia, que se marcharon excesivamente pronto, pero que todos les tenemos en nuestro recuerdo, también a mis abuelos Pedro y Anita, que en paz descansen, que junto a mi tío Juanjo, me criaron y enseñaron desde pequeño las lecciones más importantes de la vida, esas que no se explican en la escuela.

En este apartado no podía faltar mi familia húngara, que a pesar de haberles "robado" a su hija y llevarla a 3000 kms de ellos, jamás han parado de apoyarnos y querernos, pese a las diferencias de lengua y pese a la diferencia de cultura.

Gracias a Barbara (sin tilde, que es húngaro), la chica de mi vida. Gracias por ser tan fuerte como para emprender un camino junto a mí, lejos de tu familia. Gracias por tu apoyo incondicional. Gracias por ser tan buena persona. Gracias por ser una gran mamá. Y Gracias por darme a Emma, lo más bonito del mundo. 


\section{FUNDING SUPPORT}

This work has been supported by a PhD scholarship of the Technical University of Madrid (UPM). 


\section{INDEX OF CONTENTS}

Index of Tables

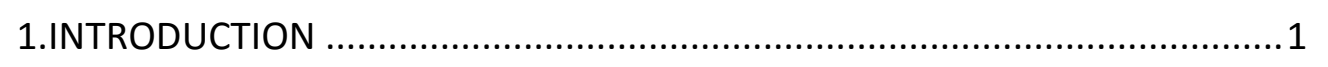

1.1.INTRODUCTION OF THE INFRARED THERMOGRAPHY ......................1

1.1.1. HEAT EXCHANGE BETWEEN THE HUMAN BODY AND THE ENVIRONMENT ........................................................................... 1

1.1.1.1.Thermal transfer by conduction ..................................2

1.1.1.2.Thermal transfer by convection .................................2

1.1.1.3.Thermal transfer by radiation.......................................2

1.1.1.4.Thermal transfer by evaporation.................................. 3

1.1.2.HISTORY AND APPLICATIONS OF INFRARED

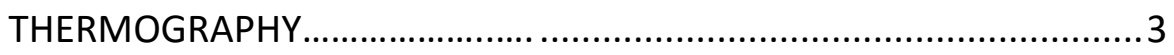

1.1.2.1.War field .......................................................................

1.1.2.2.Industrial area and construction.................................4

1.1.2.3.Medical field ............................................................... 5

1.1.2.3.1.Breast Cancer......................................................

1.1.2.3.2.Other medical Fields.......................................

1.1.2.4.Animal Field................................................................... 9

1.1.2.5.Sport Field.........................................................................10

1.2.FACTORS INFLUENCING THE USE OF INFRARED THERMOGRAPHY IN

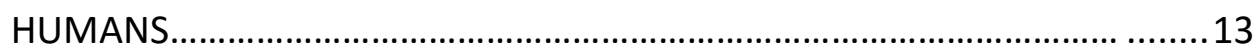

1.2.1.ENVIROMENTAL FACTORS …............................................... 14

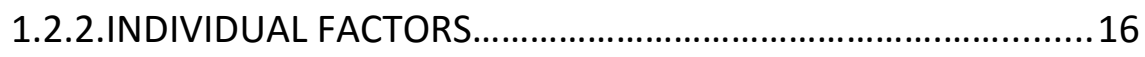

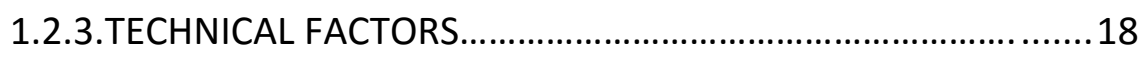

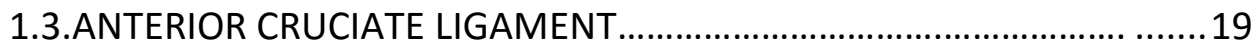

1.3.1.ANTERIOR CRUCIATE LIGAMENT RUPTURE........................19 
1.3.3.ANTERIOR CRUCIATE LIGAMENT AND THERMOGRAPHY.......20

1.3.4. IRT AS A TOOL TO MONITOR SKIN TEMPERATURE ALONG THE RECOVERY PROCESS OF AN ANTERIOR CRUCIATE LIGAMENT SURGERY.

1.3.4.1.Study 1. Thermal evolution of lower limbs during a rehabilitation process after Anterior Cruciate Ligament surgery: Summary 22

1.3.4.2.Study 2. Quantification of thermal asymmetry at the beginning and at the end of rehabilitation after anterior cruciate ligament reconstruction 22

1.3.3.3.Study 3. Thermal evolution of lower limbs 18 months from Anterior Cruciate Ligament rehabilitation. 23

1.3.4.4.Study 4. Quantification of thermal asymmetry between the injured leg and the non-injured leg: After one year and a half from the rehabilitation of the anterior cruciate ligament reconstruction .23

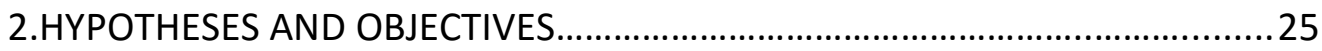

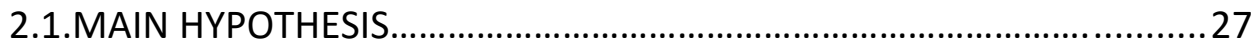

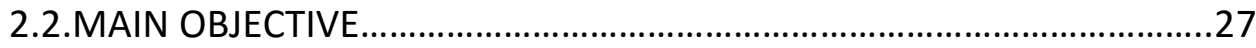

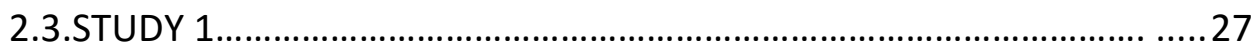

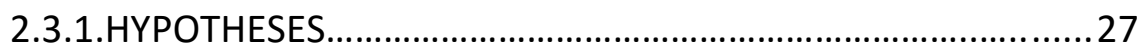

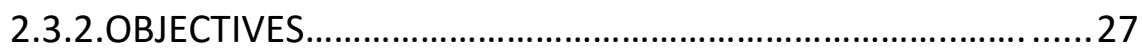

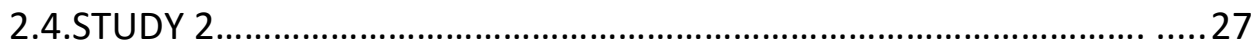

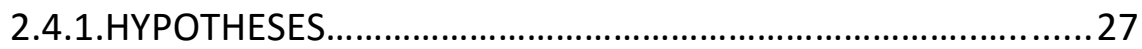

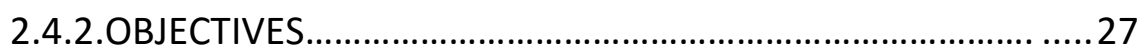

2.5.STUDY 3

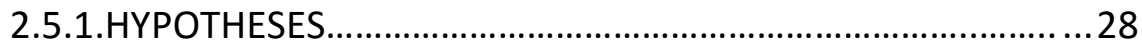

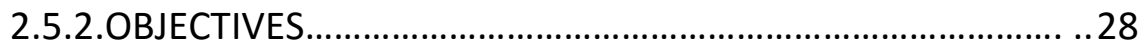

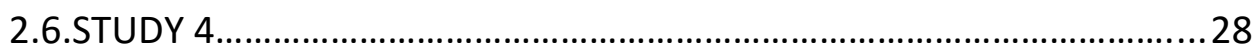

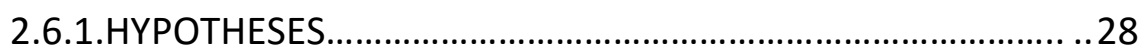

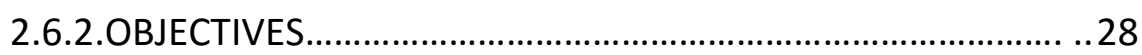

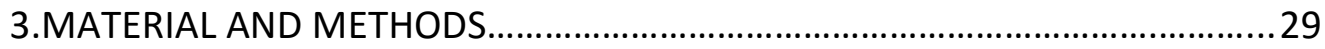

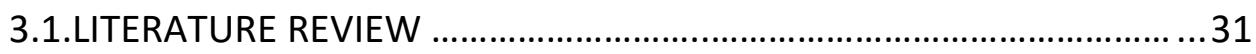

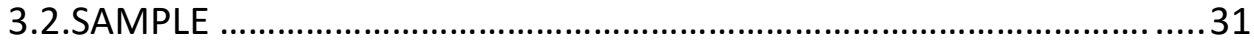

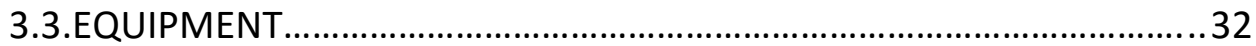

3.3.1.THERMOGRAPHIC EVALUATION EQUIPMENT........................32

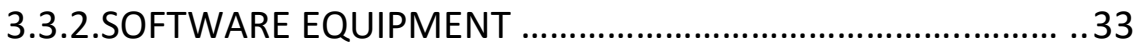

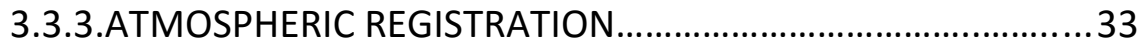




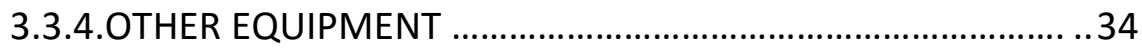

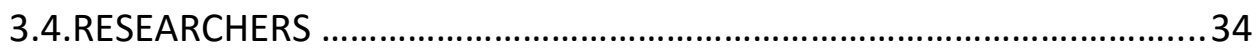

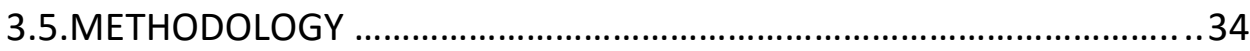

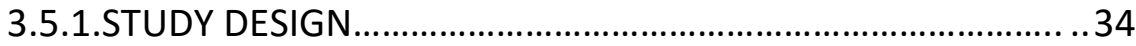

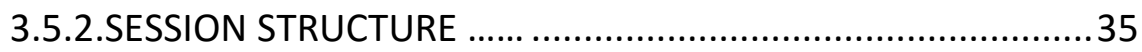

3.5.3.INFLUENCING FACTORS REGISTRATION_.............................36

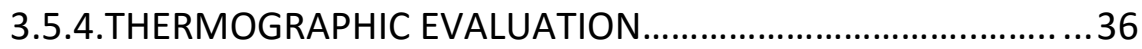

3.5.5.HOSPITAL REHABILITATION PROGRAM...................................38

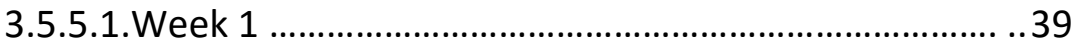

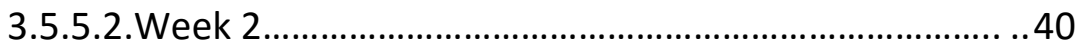

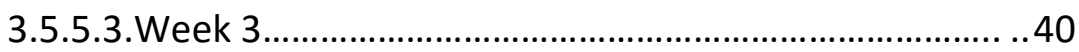

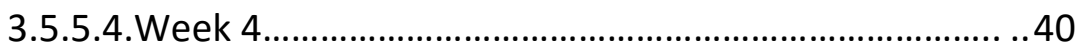

3.5.5.5.Week 5 …………............................................................ 41

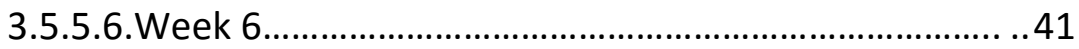

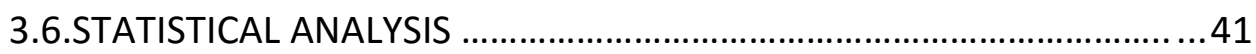

3.6.1.SELECTION OF REGION OF INTEREST...................................41

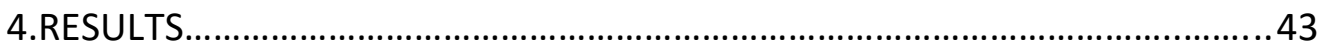

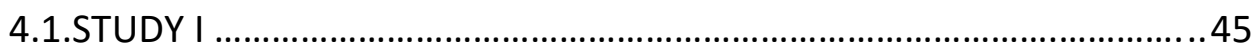

4.1.1.ANALYSIS OF TEMPERATURE...................................................45

4.1.2.THERMOGRAPHIC PROFILE OF AN ACL INJURY BEFORE AND

AFTER THE REHABILITATION PROGRAM ...................................47

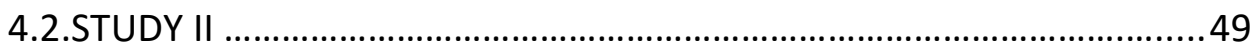

4.2.1.MAXIMUM TEMPERATURES. ANTERIOR VIEW.....................49

4.2.2.MAXIMUM TEMPERATURES. POSTERIOR VIEW.....................50

4.2.3.AVERAGE TEMPERATURES. ANTERIOR VIEW.........................50

4.2.4.AVERAGE TEMPERATURES: POSTERIOR VIEW.......................50

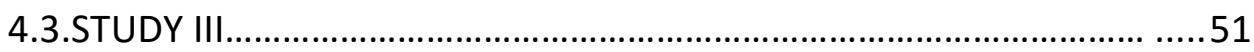

4.3.1.ANALYSIS OF TEMPERATURE.................................................51

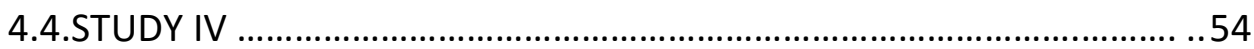

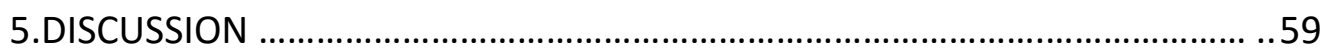

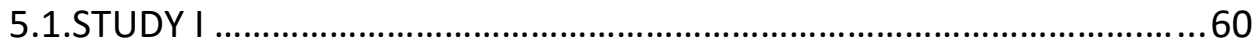

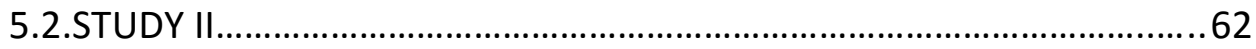

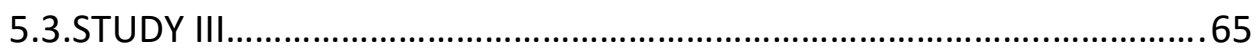

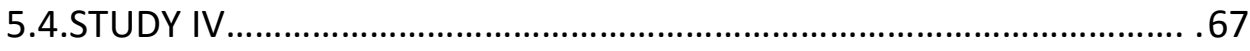

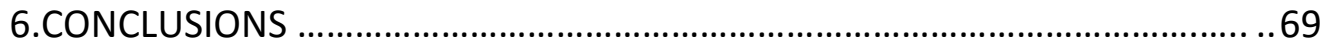


6.1.CONCLUSION OF THE MAIN OBJECTIVE........................................... 71

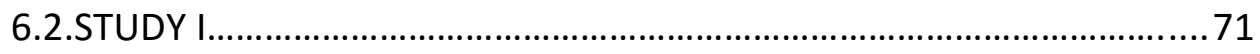

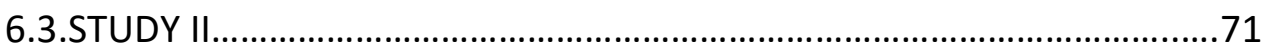

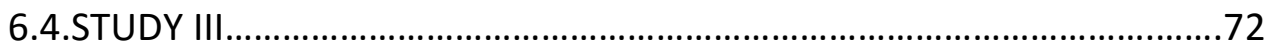

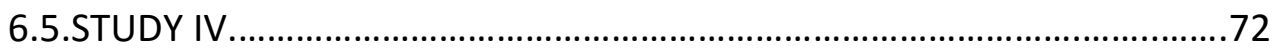

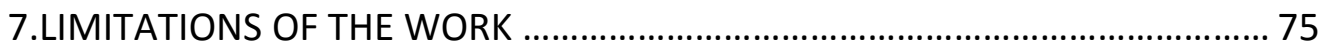

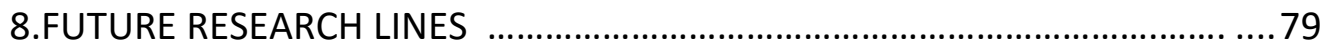

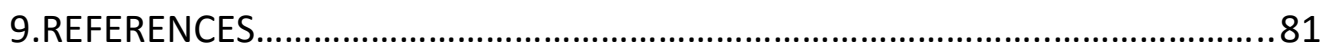

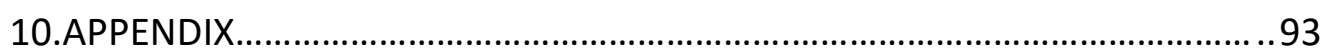

10.1.DATA COLLECTION INFORMATION ...............................................95

10.2.ETHICS COMMITTEE REPORT OF THE TECHNICAL UNIVERSITY OF

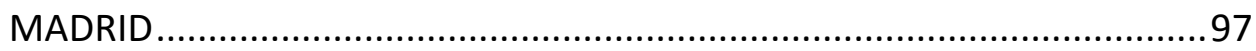

10.3.TRAINING PROTOCOL AFTER THE SIX WEEKS OF REHABILITATION ..99 
Table 1.- Advantages and disadvantages of diagnostic methods for breast cancer......................08

Table 2.- General characteristics of IRT camera T335 (FLIR Systems, Sweden)............................33

Table 3.- General characteristics of the weather station, model BAR-908HG (Oregon Scientific,

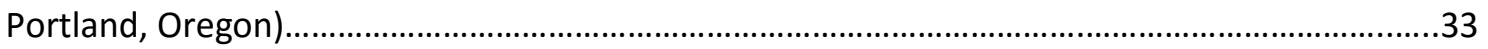

Table 4.- Phases of rehabilitation related to the week of rehabilitation .......................................39

Table 5.- Injured Leg. Average values of the anterior (A-) and posterior ( $\mathrm{P}-$ ) view: TL (Thigh Lateral), TM (Thigh Medial), LL (Leg Lateral), LM (Leg Medial), KL (Knee Lateral), KM (Knee Medial)

. .46

Table 6.- Non-injured Leg. Average values of the anterior (A-) and posterior (P-) view: TL (Thigh Lateral), TM (Thigh Medial), LL (Leg Lateral), LM (Leg Medial), KL (Knee Lateral), KM (Knee Medial)

Table 7.- Average temperature $\left({ }^{\circ} \mathrm{C}\right)$ difference for the thermal profile of the postoperative period of the ACL between the first and last week of rehabilitation

Table 8.- Maximum temperature $\left({ }^{\circ} \mathrm{C}\right)$ differences between the first and last week. $\left({ }^{*} p<0.05\right.$

$* * p<0.01)$

Table 9.- Mean of the maximum temperature of the anterior and posterior views* $(p<.01)$

$* *(p<.05)$ .50

Table 10.- Mean of the average temperature of the anterior and posterior views $*(p<.01)$

Table 11.- Injured leg-Average values of the anterior (A-) and posterior (P-) view: TL (thigh lateral), TM (thigh medial), LL (leg lateral), LM (leg medial), KL (knee lateral), KM (knee medial). $\left({ }^{*} \mathrm{p}<.05 * * \mathrm{p}<.01\right)$

Table 12.- Non-injured leg. Average values of the anterior (A-) and posterior (P-) view: TL (thigh lateral), TM (thigh medial), LL (leg lateral), LM (leg medial), KL (knee lateral), KM (knee medial). $\left({ }^{*} \mathrm{p}<.05 * * \mathrm{p}<.01\right)$

Table 13.- Average temperature difference between P1 and P2 $\left({ }^{\circ} \mathrm{C}\right) \quad\left({ }^{*} \mathrm{p}<.05{ }^{* *} \mathrm{p}<.01\right)$

Table 14.- General averaged skin temperature $\left(T_{s k}\right)$ differences for injured and non-injured leg

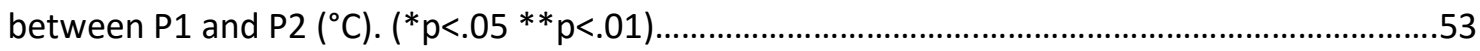

Table 15.- Maximum skin temperature $\left(\mathrm{T}_{\mathrm{sk}}\right)$ differences between P1 and P2 $\left({ }^{\circ} \mathrm{C}\right) .\left({ }^{*} \mathrm{p}<.05\right.$ $* * p<.01)$.

Table 16.- Mean values of the maximum and average temperatures of the anterior and posterior views in both periods (P) of the injured and non-injured leg (NON INJ). ${ }^{*}(p<0.01)$ $* *(p<0.05)$ .55 


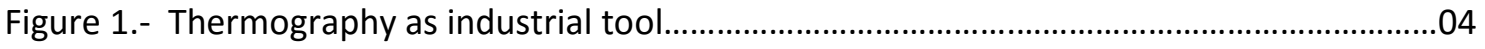

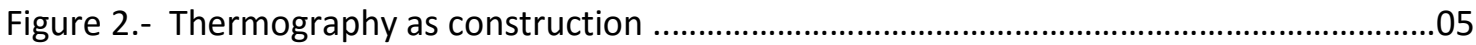

Figure 3.- This image shows a thermogram of the breasts and the difference between the left

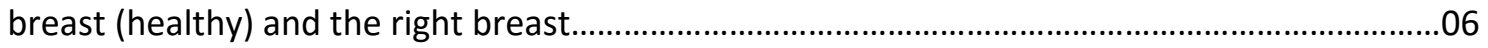

Figure 4.- Equine thermogram shows the difference of temperature between the two

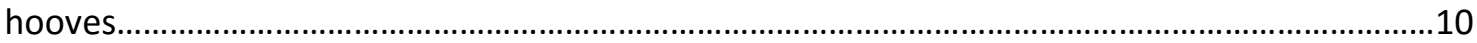

Figure 5.- This thermogram shows the temperature difference between an injured leg (right

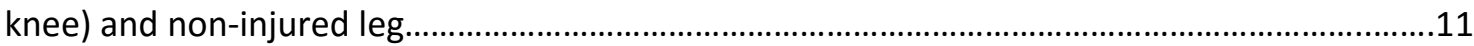

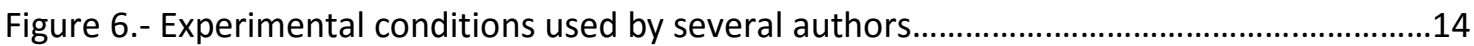

Figure 7.- Representation of the ACL rupture and the surgery process.......................................19

Figure 8.- Mechanism of production of injury of $A C L$ of the subjects who participated in this

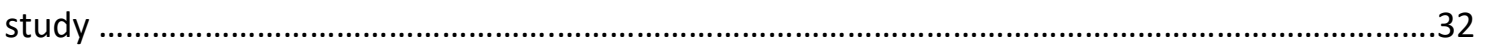

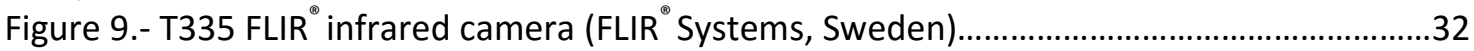

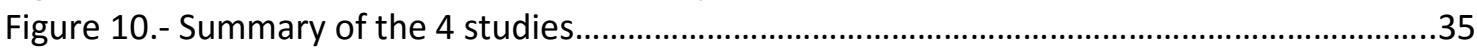

Figure 11.- Thermal images with the distribution of the 6 areas of the anterior view (left) and 6 areas of the posterior view (right): TL (Thigh Lateral), TM (Thigh Medial), LL (Leg Lateral), LM (Leg Medial), KL (Knee Lateral), KM (Knee Medial) of the Injured (I) and Non-Injured (NI) leg..38 Figure 12.- Maximum and average values of temperature of the injured and non-injured leg in

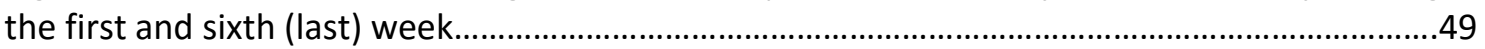
Figure 13.- Maximum and mean values of temperature of the injured and non-injured leg in P1 and $\mathrm{P} 2$ 


\section{INDEX OF ABBREVIATIONS}

\section{ACL Anterior Cruciate Ligament}

AV Anterior View

I Injured

IR Infrared

IRT Infrared Thermography

KL Knee Lateral

KM Knee Medial

LL Leg lateral

LM Leg Medial

NI Non-injured

PO Time point before the rehabilitation program (First week of rehabilitation)

P1 Time point when the rehabilitation program has finished (Last week of rehabilitation)

P2 Time point 18 months after $P 1$

PV Posterior View

SD Standard Desviation

TL Thigh Lateral

TM Thigh Medial

$T_{\text {sk }} \quad$ Skin Temperature

$x \quad$ Average

$\Delta \mathrm{T}_{\text {sk }} \quad$ Difference of skin temperature 


\section{LIST OF PUBLICATIONS}

1. Piñonosa Cano, S., Sillero-Quintana, M., Milanovic, L., Coterón, J., \& Sampedro, J. (2013). Thermal evolution of lower limbs during a rehabilitation process after anterior cruciate ligament surgery. Kinesiology (Zagreb, Croatia), 45(1), 121-129. JCR

2. Piñonosa Cano, S., Sillero-Quintana, M., Bouzas Marins, J. C., Milanovic, L., \& Sampedro, J. (2015). Quantification of thermal asymmetry at the beginning and at the end of rehabilitation after anterior cruciate ligament reconstruction. Kinesiology (Zagreb, Croatia). JCR SUBMITTED

3. Piñonosa cANO, S., Sillero-Quintana, M., Bouzas Marins, J. C., Szendrei, B., \& Sampedro, J. (2015). Thermal evolution of lower limbs after one year and a half from Anterior Cruciate Ligament rehabilitation. Disability and Rehabilitation. JCR SUBMITTED

4. Piñonosa Cano, S., Sillero-Quintana, M., Bouzas Marins, J. C., \& Sampedro, J. (2015). Quantification of thermal asymmetry between the injured leg and the non-injured leg: After one year and a half from the rehabilitation of the anterior cruciate ligament reconstruction. International Journal of Sports Science. JCR SUBMITTED

5. Piñonosa Cano, S., \& Sampedro, J. (2012). Analysis of the production mechanism of anterior cruciate ligament of the injury from the postoperative participants in the "Hospital Clínico de San Carlos de Madrid". Revista Española de Educación Física y Deporte (Madrid), 400, 129-134.

6. Piñonosa Cano, S., Sampedro, J., \& Fernández Cuevas, I. (2012). La termografía como nueva herramienta de evaluación en baloncesto. Estudio piloto realizado a un jugador profesional de la ACB. Cuadernos de psicología del deporte, 12(s1), 51-56.

7. Piñonosa Cano, S., García, M. A., Sillero-Quintana, M., Gómez, P. M., Fernández, I., Szendrei, B., et al. (2011). Thermographic profile for the rehabilitation of the ACL rupture, ECCS, Liverpool John Moores University.

8. Costa, F., Piñonosa Cano, S., Gómez, P., Sillero-Quintana, M., \& Merussi, C. (2012). Infrared thermography to quantify the risk of breast cancer. Bioimages, 20, 1-7. 
9. Bouzas Marins, J. C., Gomes Moreira, D., Piñonosa Cano, S., Sillero-Quintana, M., Dias Soares, D., de Andrade Fernandes, A., et al. (2014). Time required to stabilize thermographic images at rest. Infrared Physics \& Technology, 65(0), 30-35. JCR

10. Bouzas Marins, J. C., Fernandes, A. A., Piñonosa Cano, S., Moreira, D. G., da Silva, F. S., Costa, C. M. A., et al. (2014). Thermal body patterns for healthy Brazilian adults (male and female). Journal of Thermal Biology, 42, 1-8. JCR

11. Magno, C., Sillero-Quintana, M., Piñonosa Cano, S., Gomes, D., Brito, C., De Andrade, A., Azambuja, G., \& Bouzas Marins, J. C. (2015). Daily Oscillations of Skin Temperature in Militaries Using Thermography. Journal of the Royal Army Medical Corps (United Kingdom). Retrieved 24-01-2016, from DOI: 10.1136/jramc-2015-000462 JCR

12. Fernández-Cuevas, I., Bouzas Marins, J. C., Arnáiz Lastras, J., Gómez Carmona, P. M., Piñonosa Cano, S., García-Concepción, M. Á., et al. (2015). Classification of factors influencing the use of infrared thermography in humans: A review. Infrared Physics \& Technology, 71, 28-55. JCR 


\begin{abstract}
Infrared thermography (IRT) is a safe and non-invasive tool used for examining physiological functions based on skin temperature $\left(T_{\text {sk }}\right)$ control. Thermograms from 25 anterior cruciate ligament $(A C L)$ surgically operated patients ( 2 female, 23 male) were taken with a FLIR infrared camera according to the protocol established by the International Academy of Clinical Thermology (IACT). This work consists of 4 studies. Studies 1 and 3 were related to establish the probable thermal difference among different moments of an $A C L$ rupture after surgery: before starting the rehabilitation (P0), at the end of rehabilitation (P1) and 18 months from the end of rehabilitation (P2). For this purpose, on the other hand, studies 2 and 4 were related to establish the skin thermal difference $\left(T_{s k}\right)$ between the injured and the non-injured leg in P0, P1 and P2. Results of the first study showed significant temperature increases in the posterior thigh area between P0 and P1 probably due to a compensatory mechanism. According to this, we can conclude that temperature of the posterior area of the injured and noninjured leg has increased from the first to the last day of the rehabilitation process. In the second study we found significant temperature differences between the injured and non-injured leg in both stages of rehabilitation $(p<.01)$. On the one hand, the temperature of the injured leg is higher in the anterior view and the temperature of the non-injured leg is higher in the posterior view. By the time the patients had recovered from the reconstruction, thermal imbalances should have not been shown between symmetrical parts, but differences seemed to be still latent.. Study 3 shows that temperatures seem to be higher after a year and a half (P2) than in P1. Study 4 shows how thermal values 18 months later seemed to be normalized between both
\end{abstract}


legs. No significant differences were found between the injured leg and the noninjured leg after one year and a half of the rehabilitation process. Considering results from Study 3 and 4 we can conclude that patients seemed to have recovered from a thermal point of view. The temperature in P2 was higher but symmetrical.

Key words: Injury, knee, skin temperature, thermal evolution, $A C L$, infrared thermography. 


\section{RESUMEN}

La termografía infrarroja (IRT) es una herramienta segura y no invasiva utilizada para examinar funciones fisiológicas que se basan en el control de temperatura de la piel $\left(T_{s k}\right)$. Termogramas de 25 pacientes intervenidos quirúrgicamente del ligamento cruzado anterior (LCA) (2 mujeres, 23 hombres) fueron tomadas con una cámara de infrarrojos FLIR de acuerdo con el protocolo establecido por la Academia Internacional de Termología Clínica (IACT). Este trabajo consiste en 4 estudios. Los estudios 1 y 3 describen la diferencia térmica entre los diferentes momentos tras la operación del ligamento cruzado anterior: antes de comenzar la rehabilitación (P0), al final de la rehabilitación (P1) y 18 meses tras finalizar la rehabilitación (P2). Por otra parte, los estudios 2 y 4 describen la diferencia de temperatura de la piel (Tsk) entre la pierna lesionada y la pierna no lesionada en P0, P1 y P2. Los resultados del primer estudio mostraron aumentos significativos de temperatura en la zona posterior de los muslos entre P0 y P1, probablemente debido a un mecanismo de compensación. De acuerdo con esto, se puede concluir que la temperatura de la zona posterior de la pierna lesionada y no lesionada se ha incrementado desde el primero hasta el último día del proceso de rehabilitación. En el segundo estudio se encontraron diferencias significativas de temperatura entre la pierna lesionada y no lesionada en ambas etapas de la rehabilitación $(p<.01)$. Por un lado, la temperatura de la pierna lesionada es mayor en la vista anterior. Por otro lado, la temperatura de la pierna no lesionada es mayor en la vista posterior. Una vez que los pacientes se han recuperado de todo el proceso, no deberían existir desequilibrios térmicos entre partes simétricas del cuerpo, pero las diferencias todavía estaban latentes. El tercer estudio muestra que la temperatura es más alta en P2 que en P1. El 
cuarto estudio muestra cómo los valores térmicos entre ambas piernas en P2 se han normalizado entre ambas piernas. No se encontraron diferencias significativas entre la pierna lesionada y la pierna no lesionada después de 18 meses tras el proceso de rehabilitación. Considerando los resultados del studio 3 y 4, podemos concluir que se ha llegado a la recuperación total desde un punto de vista térmico. La temperatura es más elevada en $\mathrm{P} 2$ pero simétrica.

Palabras clave: Lesión, rodilla, temperatura de la piel, evolución térmica, LCA, termografía infrarroja. 
1. INTRODUCTION 


\section{INTRODUCTION}

\subsection{INTRODUCTION OF THE INFRARED THERMOGRAPHY}

Infrared thermography (IRT) is a technique that allows visualization of the heat radiated from a body. The camera captures the infrared emission of the body, a spectrum that is not visible to humans (Hildebrandt et al., 2010; Pascoe et al., 2001).

There are clear indications that thermography is a valid technology (Ammer, 2008; Ring, 1990; Zaproudina et al., 2006), which is both non-invasive and low-cost, that rapidly produces a non-contact recording of the energy irradiated from the body surface (Chen et al., 2005; George et al., 2008; Piñonosa et al., 2013).

The thermographic camera records heat emission as infrared radiation from each body part. Hyperthermic images appear when subcutaneous inflammatory reactions occur (Mangine et al., 1987). These reactions enhance the blood flow due to the increased cell activation.

Many authors have studied the rules of thermodynamics and heat transfer. We recommend their publications in order to go into detail such as (Serway \& Beichner, 2002), (Incropera, 1999), (Sigalés, 2003) or any other reference.

\subsubsection{HEAT EXCHANGE BETWEEN THE HUMAN BODY AND ENVIRONMENT}

The high metabolic activity of human bodies generates thermal energy which must be dissipated to maintain correct physiological processes of the body (Wilmore \& Costill, 2008).The mechanisms used by the human body to transfer this energy are: Conduction, convection, radiation and evaporation. 


\subsubsection{Thermal transfer by conduction}

Heat conduction is the direct transfer of thermal energy between molecules when they crash to each other. The molecule that moves faster (and carries higher temperature) transmits part of the energy to the other one moving slower (lower temperature) (Serway \& Beichner, 2002). Conduction happens in solid, liquid and gaseous substances, but the solid one is the most important (Serway \& Beichner, 2002). The core body of human beings is around $37^{\circ} \mathrm{C}\left(34^{\circ} \mathrm{C}\right.$ when resting) (Lee \& Cohen, 2008).

\subsubsection{Thermal transfer by convection}

Convection is the mechanism of heat transfer through a moving fluid (gas or liquid). Unlike conduction, which is performed between a fluid and a solid surface or on the surface of two fluids which are immiscible, convection takes place within the fluid. Most gases are invisible to a infrared camera, so convection is often directly viewed only on liquids or indirectly on the surface of the solids. In the human body this kind of thermal transfer depends on many variables such as the temperature difference between ambient and skin and the direction of air flow (Incropera, 1999).

\subsubsection{Thermal transfer by radiation}

The heat transfer by emission and absorption of radiation is called thermal transfer by radiation. Thermal radiation is one form of electromagnetic radiation. The bodies emit thermal radiation due to its temperature: The higher the temperature is, the more thermal radiation is emitted (Incropera, 1999), but depends on the emissivity of each material (Serway \& Beichner, 2002).

The $60 \%$ of energy dissipated by the human skin is in the form of infrared radiation (Wilmore \& Costill, 2008) and the remaining 40\% corresponds to convection. 


\subsubsection{Thermal transfer by evaporation}

When exercising, about the $80 \%$ of heat loss in a subject corresponds to evaporation. At rest this percentage decreases to $10 \%$ or $20 \%$ of body heat loss (Wilmore \& Costill, 2008). Sweat evaporation and breathing are the main ways of the body to dissipate the heat (Galindez, 2010).

\subsubsection{HISTORY AND APPLICATIONS OF INFRARED THERMOGRAPHY}

Infrared thermography is a powerful tool to study the surface temperature of the human body. It is fast, it is not invasive, emits no radiation, is painless and a noncontact technique (Tkacova, 2010).

Since John Herschel obtained the first infrared image in 1840, which was called "thermogram", thermography has evolved constantly. First study using thermography indexed in Medline was in 1951 (Mishin \& Garbuzov, 1951). The first study using thermography in humans was published in 1957 (Lawson, 1957). From then, especially in the 70's, many studies were published.

A great step for this technology was the quantitative thermography. It began since analyzing and storing the images digitally was possible (Ring, 2007). In the 1970s, the computerized infrared imaging and the incorporation of colors in the thermograms increased the possibility of achieving better quantification and images that allowed thermography to penetrate into different areas (Birch et al., 1969; Dittmar et al., 2006; Geneve, 1971; Gershon-Cohen \& Haberman, 1968; Isard et al., 1972; Keyl \& Lenhart, 1975; Reinberg, 1975; Rothchild \& Barnes, 1952; Steketee, 1976; Yang, 1988). This breakthrough marked the beginning of quantitative thermography (Ring, 1990), and sports medicine was not an exception. 
For many years research studies have described the capability of infrared thermography (IRT) to detect alterations in sports injuries by showing the temperature of the tissues involved (Keyl \& Lenhart, 1975).

This tool was used in many fields along history:

\subsubsection{War field}

Its marketing began in the Second World War (Ring, 2007) for military purposes as night vision.

\subsubsection{Industrial area and construction}

In this field, thermography is used to control power grids, stress analysis thereof, electronics and microelectronics (Balageas, 2007; Day, 2005; Lyon, 2004; Osorio Cruz \& Caballero Bello, 2005), air space industry and maintenance of machinery (Marinetti et al., 2000; Meola et al., 2004; Sham et al., 2008), and as a detection method of hot or cold spots (Viale et al., 2007). Figure 1 shows IRT used as a tool to detect the heat in electrical systems. Figure 2 shows how IRT can detect the heat loss in buildings.

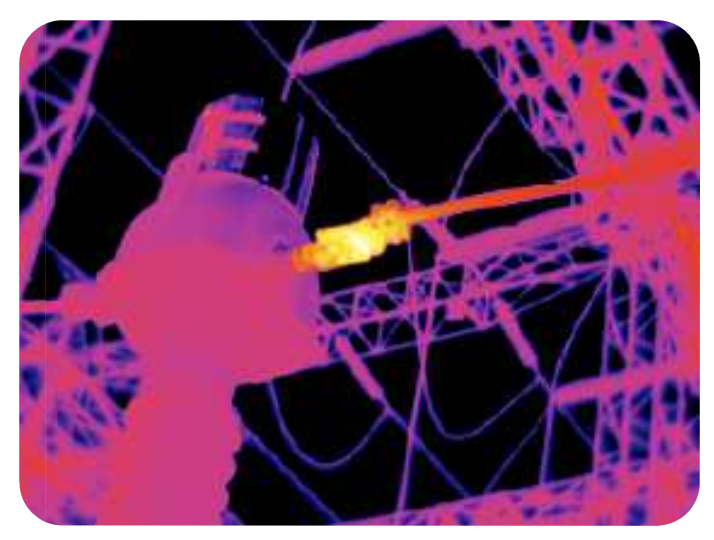

Figure 1.- Thermography as industrial tool 


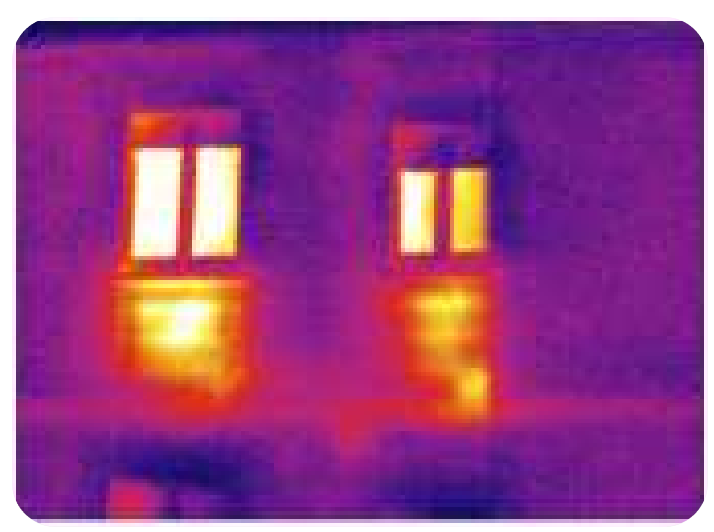

Figure 2.- Thermography as construction tool

In addition it is also considered for the study of works of art (Avdelidis \& Moropoulou, 2004; Grimnes, 2000).

\subsubsection{Medical field}

\subsection{Breast cancer}

The global burden of cancer continues to increase largely because of the aging and growth of the world population alongside an increasing adoption of cancercausing behaviors, particularly smoking, in economically developing countries. Based on the GLOBOCAN 2012 estimation, about 1.6 million new cancer cases and 522.000 cancer deaths are estimated to have occurred in 2012; of these, $47 \%$ of the cases and $37,4 \%$ of the deaths occurred in the economically developing world. Breast cancer is the most frequently diagnosed cancer and the leading cause of cancer death among women, accounting for $23 \%$ of the total cancer cases and $14 \%$ of the cancer deaths. In men, lung cancer is the leading cancer site comprising $17 \%$ of the total new cancer cases and $15 \%$ of the total cancer deaths (Costa et al., 2012). Figure 3 shows the thermal difference between a healthy breast and a cancerous breast. 


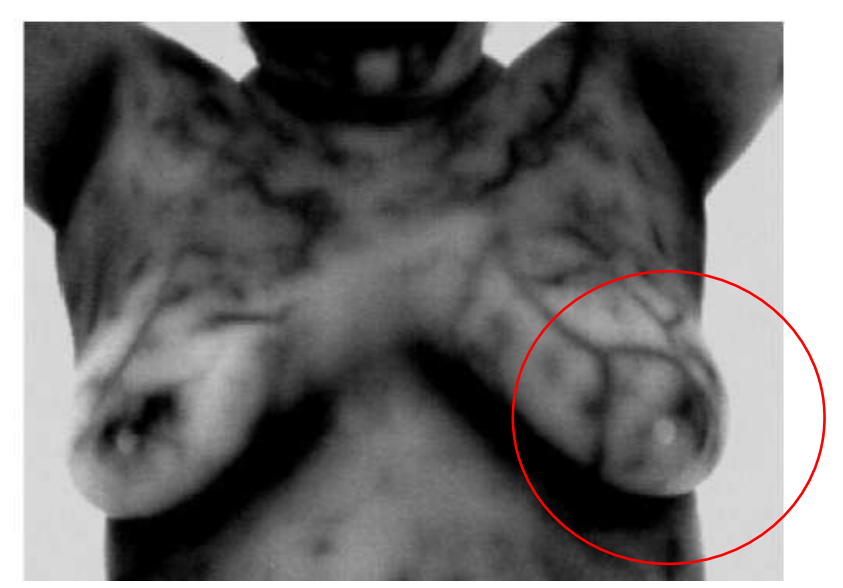

Figure 3.- Thermogram of the breasts. Healthy right breast and the cancerous left breast (Costa et al., 2012)

Breast cancer is now also the leading cause of cancer death among females in economically developing countries, a shift from the previous decade during which the most common cause of cancer death was cervical cancer (Jemal et al., 2011).

It has been observed that breast cancer can produce an increase in infrared emission causing a disparity in thermogram of breast skin thus can not only serve for early detection but also for the development of medical treatment. It is mainly based on obtaining abnormal temperatures in the breasts and later additional research by other diagnostic procedures. Therefore, the thermographic data do not initially indicate a condition or malignant situation but simply an abnormal situation (Isard et al., 1972; Zadeh et al., 2015).

The use of thermal tests on health is not something new for this purpose. The first use of thermography was in 1957 when Lawson found that the temperature of the skin over the breast cancer was higher than normal tissue. The relationship between skin temperature and breast cancer was also studied by Gautherie and Gross in 1975 (Acharya et al., 2010), who detected differences in skin temperature of healthy and cancerous breasts. However, until the late '70s, few documents showed that the 
thermographic images had a direct relationship with both the clinical findings and diagnosis and with breast pathologies. The lack of proper training, understanding the equipment and the absence of protocols has led to inappropriate use of the method and errors of interpretation of thermograms. These drawbacks of thermography were discredited by many medical professionals (Brioschi, 2006).

The mammary tumor requires a steady flow of nutrients to develop. For this, new blood vessels are created around the tumor (angiogenesis), which ultimately increases the local temperature. This temperature rise can be detected on the surface of breast cancer through examination of thermography (Costa et al., 2012).

Therefore, in the prognosis of breast cancer it is crucial the stage in which the disease is located, which is why early detection is important. Deep physical examination can locate small tumors but unfortunately these usually appear at an advanced period, that is why mammography is used but many times is very limited (Table 1). Then, thermography as an initial test appears to focus attention on those women at risk or young age (Isard et al., 1972; Koay, 2005; Markel \& Vainer, 2005; Mital, 2004; Ng, 2009; Parisky et al., 2003) .

A study done in Japan with 48 women who underwent surgery for resection of the breast, had thermographic images collected from the suspected area and the underlying tissues, in addition to measuring the local temperature using a thermometer inserted in breast tissue. The temperature was found higher on the diseased tissue, which coincided with the images of the thermograms. Thermograms were found abnormal in 43 of the 48 women (Yahara et al., 2003). 
Table 1.- Advantages and disadvantages of diagnostic methods for breast cancer

(Costa, et al., 2012)

\begin{tabular}{|c|c|c|}
\hline EXAM & Advantages & Disadvantages \\
\hline MAMMOGRAPHY & $\begin{array}{l}\text { Reduction in mortality from breast cancer. } \\
\text { Relative risk reduction and absolute. } \\
\text { Increased survival time from diagnosis. } \\
\text { Reduced need for mastectomy (Jorgensen et al., } \\
\text { 2007; Youk \& Kim, 2010). }\end{array}$ & $\begin{array}{l}\text { Low sensitivity for dense breasts. } \\
\text { High cost. } \\
\text { Patient's exposure to radiation. } \\
\text { Little accuracy when the tumor is } \\
\text { located deep. } \\
\text { Some patients report discomfort } \\
\text { during the exam (Foster, 1998). }\end{array}$ \\
\hline ULTRASOUND & $\begin{array}{l}\text { Low cost. } \\
\text { Does not require use of contrast. } \\
\text { Well tolerated by patients. } \\
\text { More accessible than complex exame like } \\
\text { magnetic resonance (Youk \& Kim, 2010). }\end{array}$ & $\begin{array}{l}\text { Obsolete tools. } \\
\text { Lack of skilled operators. } \\
\text { Inability to detect microcalcifications } \\
\text { Higher rates of false positives than } \\
\text { mammography (Youk \& Kim, 2010). }\end{array}$ \\
\hline $\begin{array}{l}\text { CLINICAL } \\
\text { EXAMINATION }\end{array}$ & $\begin{array}{l}\text { Helps detect breast cancer. } \\
\text { Easily applied (Kennedy et al., 2009). }\end{array}$ & $\begin{array}{l}\text { Low sensitivity. } \\
\text { Does not reduce the mortality rate. } \\
\text { Low adherence. } \\
\text { Increases the number of biopsies } \\
\text { (Broderse et al., 2010; Kennedy et } \\
\text { al., 2009; Sadler et al., 2007). }\end{array}$ \\
\hline MAGNETIC & $\begin{array}{l}\text { Locates precisely the tumor. } \\
\text { It has high sensitivity, even in dense breasts. }\end{array}$ & $\begin{array}{l}\text { High cost. } \\
\text { Difficult access to most of the } \\
\text { population. }\end{array}$ \\
\hline RESONANCE & $\begin{array}{l}\text { Determines the size of the malignant injury known } \\
\text { (Alvares \& Michell, 2003; Hlawatsc et al., 2002). }\end{array}$ & $\begin{array}{l}\text { Low specificity (Alvares \& Michell, } \\
\text { 2003). }\end{array}$ \\
\hline BIÓPSY & $\begin{array}{l}\text { Lower inadequate and suspicious rates, allowing } \\
\text { easier grade assessment and ancillary testings } \\
\text { (hormome receptors, HER2) in cases of cancer (Tse } \\
\text { et al., 2010). }\end{array}$ & $\begin{array}{l}\text { One can confidently diagnose } \\
\text { papillary lesion, although there is } \\
\text { still significant false positive and } \\
\text { false negative rates, even with } \\
\text { immunohistochemistry (Tse et al., } \\
\text { 2010). }\end{array}$ \\
\hline $\begin{array}{l}\text { INFRARED } \\
\text { THERMOGRAPHY }\end{array}$ & $\begin{array}{l}\text { Noninvasive. } \\
\text { Painless. } \\
\text { Low cost. } \\
\text { Not radiate. } \\
\text { Portability. } \\
\text { Easy access to the population }(\mathrm{Ng}, 2009 \text {; Tang, et } \\
\text { al., 2008). }\end{array}$ & $\begin{array}{l}\text { Not able to locate precisely the } \\
\text { tumor in order to lead to surgical } \\
\text { excision. } \\
\text { Depends on optimal conditions to } \\
\text { maintain the accuracy of the method } \\
\text { (Kennedy, et al., 2009). }\end{array}$ \\
\hline
\end{tabular}




\subsection{Other medical fields}

Thermography has been used in several fields in medicine to investigate different diseases (Staffa et al., 2016; Ring, 2004, 2006, 2007; Ring \& Ammer, 2000; Ring \& Phillips, 1984).

Examples include studies of thyroid diseases (Helmy et al., 2008), dermatological diseases (Di Carlo, 1995; Mohammed et al., 2014), back pain (Roy et al., 2013; Feng et al., 1998; Pichot, 2001; Ping \& You, 1993; Stupka \& Krumelovä, 2002), diseases of the nervous system (Brusselmans et al., 2012; LaBorde, 1989; Leisman, 1990), cardiovascular diseases (Benetos et al., 2015; Tham et al., 1990; Usuki et al., 1998), etc.

\subsubsection{ANIMAL FIELD}

In veterinary medicine, thermography is extremely useful because of the inability to communicate of the animal. Studies with cats, dogs and horses where thermography was used in the diagnosis were very positive (Donna \& Harper, 2005).

Most of the references when searching "thermography" and "Animal" leads us to investigations related to the detection of pathologies in horse riding. Their interest in this tool is increasing exponentially as diagnosis of neurological injuries and musculoskeletal systems of horses (Autio et al., 2006; Ciutacu et al., 2006; Hamilton, 1998; Kulesza et al., 2004) such as back pain, soft tissue injuries, arthritis and overloads (Shamaa \& Gohar, 2002). 


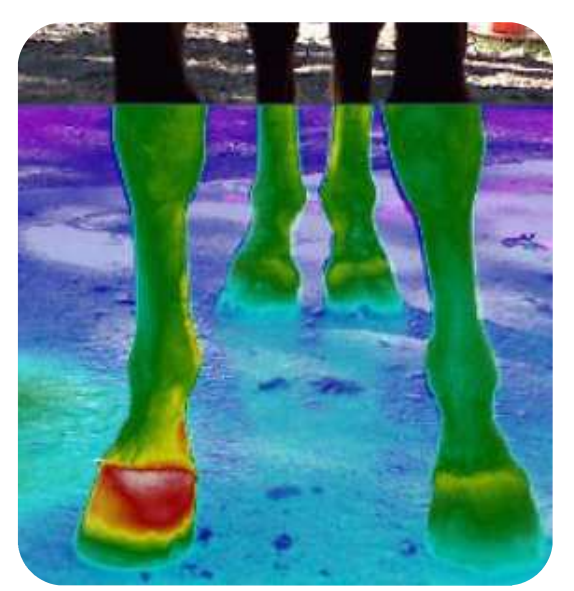

Figure 4.- Equine thermogram shows the difference of temperature between the two hooves. Retrieved 15-12-2014, from http://equinethermographyoregon.com/

The equine thermograms can detect musculoskeletal injuries several weeks before that they are latent (Figure 4), and help professionals to follow the response to treatment of horse (Ciutacu et al., 2006).

\subsubsection{SPORT FIELD}

Infrared thermography was used more than thirty years ago in sport injuries to detect the temperature of the tissues involved (Keyl \& Lenhart, 1975b), and now, with new technologies, many new studies every year are being launched (Formenti et al., 2013; Fournet et al., 2013; Perez et al., 2003; Piñonosa et al., 2013; Yabroudi \& Irrgang, 2013). The thermographic camera records the heat emission from the skin surface $\left(T_{s k}\right)$. Different colors are recorded when inflammatory reactions occur (Mangine et al., 1987).

Furthermore, thermography can detect alterations in sports injuries (Figure 5) showing the temperature of the tissues involved (Sands et al., 2007; Tkacova, 2010), as it identifies heat emission from a body part. It is a safe, non-invasive and useful tool to detect injuries such as tennis elbow, ankle injuries, fractures, spinal pain, shoulder injuries or foot pain (BenEliyahu, 1990a). 


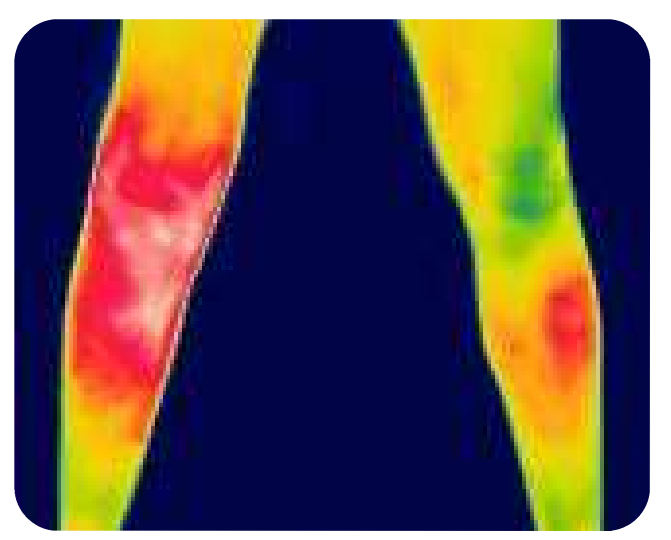

Figure 5.- This thermogram shows the temperature difference between an injured leg (right knee) and non-injured leg.

Hyperthermic images appear when there are inflammatory reactions due to an increase of the metabolism (Litscher, 2013) by increasing the blood flow through the cellular activation and hypothermic images when there is compression or degenerative processes (Čoh \& Širok, 2007).

Vasomotor and metabolic problems modify significantly the emission of body heat. The temperature of contralateral areas or of the same area at different times can be compared to check how it evolves. The thermal alteration depends on the intensity of the underlying biological phenomenon which is occurring and on the size and depth of the involved tissue. Thermography does not reveal anatomic abnormalities, but the state of the tissues (Garagiola \& Giani, 1990).

In the early days of an acute injury there is a hyperthermic peak which lasts for at least 24 hours, and then temperature decreases gradually. No pain does not mean that the injury has fully recovered, and thermography can be effective to check whether the injured area is still affected (Garagiola \& Giani, 1990).

The range of studies with positive results using thermography is quite wide, even in high-performance sports (Lopez et al., 2008). Clark and colleagues (1977) 
obtained significant results recording the distribution of skin temperature during a race. Other studies have been conducted on, for example, patellar tendinitis (Mangine, et al., 1987) and ankle injuries (Specchiulli et al., 1991), or on gymnasts (Caine et al., 1989; Meeusen \& Borms, 1992). Hildebrandt and Raschner (2009) applied thermography on alpine skiers with $\mathrm{ACL}$ tears, observing significant differences in the thermograms of the injured and non-injured leg. The thermogram of the affected knee shows a massive increase of hyperthermia under the patella that represents the inflammatory process. After six months, the knee still showed a thermal imbalance when compared to its contralateral joint.

Different authors have established ranges that indicate the temperature difference between symmetrical sides that can be considered as an injury. Thermal bilateral symmetry is justified by the concept of proportionality between contralateral body areas (Brioschi et al., 2003). Thermal values of symmetrical parts of the body surface should be similar (Ammer, 2008; Piñonosa et al., 2013) with a small range of variation. This means that the normality of a healthy subject is that these differences do not exist at any time, and when they do it means that there has been some kind of impairment. Vardasca (2008) considers abnormal asymmetric differences temperatures $\left(\Delta \mathrm{T}_{\text {sk }}\right)$ over $0.27{ }^{\circ} \mathrm{C}$ while BenEliyahu (1990a) cites $0.29^{\circ} \mathrm{C}$ and Hildebrandt et al. (2010) $0,62^{\circ} \mathrm{C}$. According to Niu et al. (2001) and Uematsu et al., (1988), a $\Delta \mathrm{T}_{\text {sk }}$ greater than $0.5^{\circ} \mathrm{C}$ between two body symmetrical segments indicates a functional disorder. Following these authors, $\Delta T_{\text {sk }}$ under these values seem to be normal. Higher impairments could mean that the subject is suffering an imbalance in some aspect of his or her body which is manifested through thermal asymmetry (Bouzas et al., 2014). There may be many reasons that cause this variation in 
temperature such as problems in technique, in the metabolic system (Brelsford \& Uematsu et al.,, 1985), in the nervous system (BenEliyahu, 1992b; Bertmaring, 2008) and the endocrine system, or any injury or overload (Čoh \& Širok, 2007), etc. Nevertheless, it has been suggested that a $\Delta \mathrm{T}_{\text {sk }}$ over $1^{\circ} \mathrm{C}$ can be considered a strong indicator of abnormality (BenEliyahu, 1992a), requiring further diagnostics protocol to identify the cause of this difference.

\subsection{FACTORS INFLUENCING THE USE OF INFRARED THERMOGRAPHY IN HUMANS}

The interpretation of a thermal image is subject to many variables and factors that may influence a remarkable way the conclusions we get, for that reason, we must be able to identify those variables or factors that can hinder the work of interpretation.

Working with IRT requires accounting for many factors that can influence either the evaluation or the interpretation of the thermal images (Zaproudina et al. 2008). Attempting to control for such a large number of factors may seem impossible, but simply being acquainted with these factors is an important step in many contexts. These factors are divided into three primary groups (Fernández-Cuevas et al., 2015) (Figure 6). 


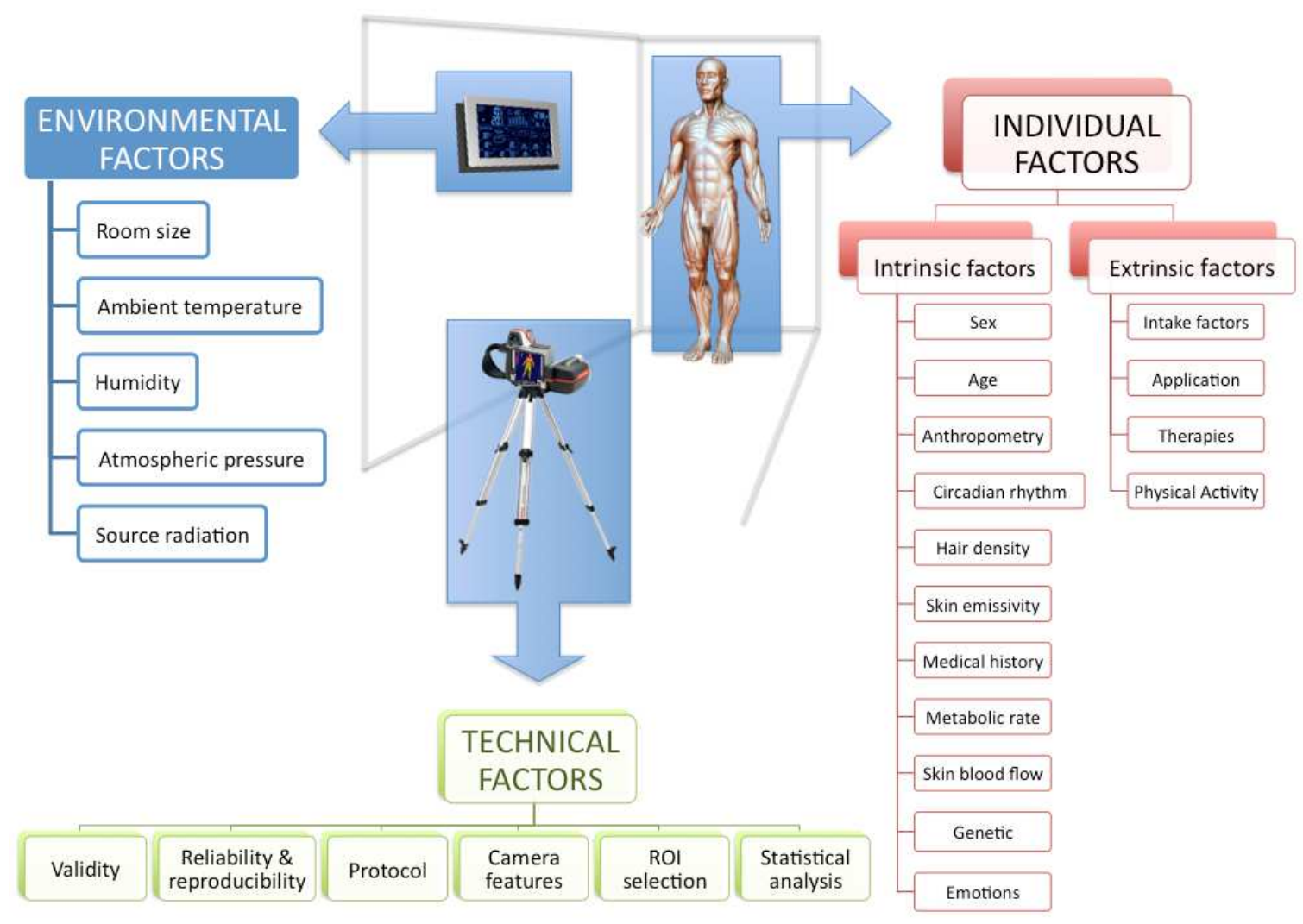

Figure 6.- Experimental conditions used by several authors based on (FernándezCuevas, et al., 2015)

\subsubsection{ENVIRONMENTAL FACTORS}

Those that are related to the place where the evaluation is performed, so that, they are easier to control.

- The minimal room size recommendation is $2 \times 3$ metres, but a larger room is desirable (Ammer \& Ring, 2007; Ring \& Ammer, 2000).

- The ambient temperature is very important for most human IRT applications (Ammer \& Ring, 2005; Harada et al., 1998; Ivanitsky et al., 2006; Pascoe et al., 2001). The majority of references suggest a temperature range of $18^{\circ} \mathrm{C}$ to $25^{\circ} \mathrm{C}$ because the subject is likely to shiver in lower temperatures and to sweat at higher temperatures (Ammer \& Ring, 2007; Chiang et al., 2008; IACT, 2002; Mabuchi et al., 1997; Ring \& Ammer, 2000). 
- About relative humidity, the majority of studies have been performed between 40\% and 70\% RH (Chudecka \& Lubkowska, 2010; Ferreira et al., 2008; Merla et al., 2010; Nakayama et al., 1981; Torii et al., 1992; Uematsu et al., et al., 1988; Zaproudina et al., 2006; Zontak et al., 1998).

- The time that is required to reach an adequate stability in $T_{s k}$ is set at approximately 15' (IACT, 2002). Generally, authors recommend waiting 15 minutes for the optimal stabilization of $\mathrm{T}_{\text {sk }}$, with a minimum of 10 minutes. Nevertheless, different equilibration periods are used throughout the literature when using IRT, ranging from 10' (Akimov \& Son'kin, 2011; Ring et al., 1974), 15' (Zaproudina et al., 2006), 20' (Abate et al., 2013; Chudecka \& Lubkowska, 2010) to 30' (Roy et al., 2006) or even 60' (Livingston et al., 1987). However, when acclimatization exceeds 30 minutes, temperature oscillation can occur, creating an asymmetry between the left and right sides of the subject. Roy and collaborators (2006) performed a study in which thermography was used to analyze the time necessary for the temperature in the region of the spine to stabilize and suggested a minimum time of 8 minutes and maximum of 16 minutes for reliable measurements (Roy et al., 2006). The recommended acclimatization time varies between studies of skin thermometry, with periods of 10 minutes (Choi et al., 1997; Ferreira et al., 2008) 15 minutes (Zontak et al., 1998) and 20 minutes (Merla et al., 2010) suggested for the subject to remain at rest in a room with controlled temperature and humidity. This variation may be influenced by environmental conditions, especially by the temperature outside the test room. This lack of consensus (Choi et al., 1997; Ferreira et al., 2008; Merla et al., 2010; Ring \& Ammer, 2000; Zontak et al., 1998) makes it difficult to determine the optimal 
acclimatization protocol because each study recommends a different acclimatization period to achieve a stable $T_{s k}$ to ensure the homogeneity of results and allow consistent interpretation and comparison of results between studies. A recent study by Bouzas Marins and collaborators (Bouzas et al., 2014) has directly analysed the optimal acclimatisation time for IRT evaluation in humans. Consequently, the objective of this study was to identify the time required to achieve a stable $T_{s k}$ at rest in a group of young men and women. They concluded that the optimal period is variable in young men and women, but the minimum acclimatisation period must be 10 minutes.

- The room should be isolated from any source of infrared radiation (e.g., windows, heating ducts, water pipes, heating lights, or airflow) (IACT, 2002).

\subsubsection{INDIVIDUAL FACTORS}

Those that are related to the subject being assessed and his/her personal characteristics that could influence skin temperature $\left(T_{s k}\right)$. These factors will be divided into intrinsic and extrinsic factors.

Intrinsic factors

- Sex may influence the $T_{\text {sk }}$ pattern (Hardy \& Du Bois, 1940). For instance, the influence of the menstrual cycle on body temperature. Much has also been published regarding the relationship of subcutaneous fat and the $T_{\text {sk }}$ differences between men and women. The metabolic rate also plays an important role in explaining gender differences in $\mathrm{T}_{\text {sk }}$. This effect has been described by several authors (Bouzas et al., 2014; Hardy \& Du Bois, 1940; Havenith, 2001; Shapiro et al.,, 1980). 
- Decreases in temperature with age may be related to a lower metabolic rate and to a decrease in heat dissipation abilities (Petrofsky et al., 2006).

- The circadian rhythm and its influence on body temperature has been widely researched and described (Bianchi et al., 1979; Chamberlain et al., 1995; Reinberg, 1975). Binder et al. (1983) and Salisbury et al. (1983) both demonstrated higher $\mathrm{T}_{\text {sk }}$ in diurnal assessments when using IRT.

- Hair plays an insulating role. Barnes (1963) described hair as an avascular substance that appears cold on a thermogram, being in thermal equilibrium with the environment.

- Medical history: During life we are exposed to many external factors (e.g., solar radiation or scars) that leave their marks on human skin, breaking and altering the thermal pattern with permanent hot/cold spots, which could influence the correct interpretation of a thermographic image.

\section{- Extrinsic factors}

- Factors that affect $T_{s k}$ or emissivity due to the consumption or intake of medications, drinks or other products that could temporarily influence $T_{\text {sk. }}$. It is often recommended that the use of medications be avoided prior to a thermographic assessment (IACT, 2002; Ring \& Ammer, 2000; Zaproudina, 2012).

- Application factors: Those that are applied directly on the skin and which affect the skin's emissivity or blood flow. Such factors include cosmetics, ointments, topical products and radiation (Hardy \& Muschenheim, 1934; IACT, 2002).

- Therapies: These influences are therapies that are applied on the skin and therefore affect the skin's radiation and temperature (Ring \& Ammer, 2000). 
- Physical activity: In this group, we will include factors that are related to physical activity and exercise, which are likely to be some of the primary sources of homeostatic disturbance in the human body (Ferreira et al., 2008; Johnson, 1992; Jones, 1998; Kenny et al., 2003; Zontak et al., 1998). We have also included other factors, such as sweating, fitness level, limb or hand dominance or specific thermal distributions that are due to a sport specialisation.

\subsubsection{TECHNICAL FACTORS}

Factors that are linked to the equipment used during the IRT evaluation. Higher resolution, novel features and superior accuracy do not imply that technical factors have less of an influence on the proper collection of human IRT data but helps to get better results in order to compare in future with new-designed cameras.

- Validity: Validity refers to something which is well founded and corresponds accurately to the real world. In this case of IRT, validity would be the ability to estimate temperatures of an object surface from its infrared radiation recorded by thermal camera.

- Accuracy : it refers to how close are the thermal readings of an IRT camera to the real temperante.

- Protocol: One of the main keypoints to improve the apptication of IRT on humans and reduce the influence of technical factois is to apply a standardized protocol (Ammer, 2008). Since IRT is applied on the medical sector, several organisations were created and published their own protocols (IACT, 2002).

- Distance: Some authors have mentioned the importance of the distance between the camera and the subject (Ring \& Ammer. 2000; Tkacova et al., 2010), but most 
of the studies use different distances depending on the measured area and the optical characteristics of the camera.

- Background: The use of an uniform background avoids reflections from others sources of radiation (Hildebrandt et al., 2010).

- Camera: Resolution, temperature range ROI selection.

\subsection{ANTERIOR CRUCIATE LIGAMENT}

\subsubsection{ANTERIOR CRUCIATE LIGAMENT RUPTURE}

$\mathrm{ACL}$ rupture is a common injury in sports (Negahban et al,, 2011). Additionally it is the most common ligamentous knee injury. The most common mechanism of production is an indirect knee trauma, typically a joint torsion in sports. Patients often describe a snapping noise followed by hemarthrosis (Teske et al., 2010). Cruciate ligaments and the collateral ligaments plays a big role at the knee stabilization. The $\mathrm{ACL}$ originates from the inner surface of the lateral condyle of the femur, runs in an anterior medial direction and inserts at the tibial plateau in the intercondyle area. Figure 7 represents the knee surgery process.

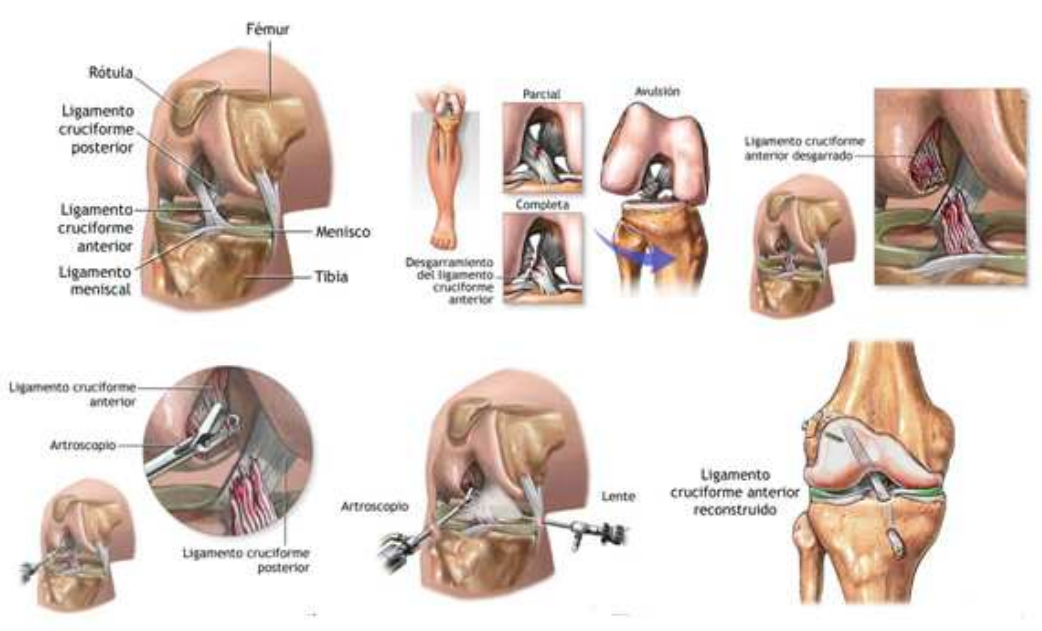

Figure 7.- Representation of the ACL rupture and the surgery procedure. Retrieved and adapted 10-09-2014 from http://adam.com 
The ACL is essential to keep stability in the knee joint. While in the young and active population with a broken $A C L$, surgery is often the best treatment option, there is controversy about the best treatment. The most popular options are the intraarticular reconstruction of the patellar tendon, the iliotibial band and hamstrings (Ventura, 2010).

ACL injuries often occur in sports as football (Alcaraz, 2007) and basketball (Namdari et al., 2011; Piñonosa et al., 2012). As an example of the importance of this injury in sport, $93 \%$ of traumatic injuries in football have been documented in the lower limbs (Wong \& Hong, 2005), and of these, one out of three are focused on the knee joint, with the result that $42.3 \%$ of the knee injuries in football are due to a $\mathrm{ACL}$ torn (Engström et al., 1990).

\subsubsection{ANTERIOR CRUCIATE LIGAMENT RECONSTRUCTION}

All subjects were operated with the same system, bone-tendon-bone that consists of replacing the ligament affected by a portion of the insertion of the hamstrings.

From the date of the operation until the start of rehabilitation an average of $34.16 \pm 12.02$ days had passed.

\subsubsection{ANTERIOR CRUCIATE LIGAMENT AND THERMOGRAPHY}

Hildebrandt and Raschner (2009) applied this tool on alpine skiers with ACL tears, finding out that the thermogram of the affected knee showed a massive increment of hyperthermia under the patella of $1.4^{\circ} \mathrm{C} \pm 0.58^{\circ} \mathrm{C}$. After six months, the knee still showed a thermal imbalance when compared to its contralateral joint.

ACL especially, present important thermal changes (Haidar et al., 2006; Piñonosa, 2013) due to two different factors, the injury itself and the reconstruction 
later. Thermal bilateral symmetry is justified by the concept of proportionality between contralateral body areas (Brioschi, et al., 2003; Bouzas et al., 2014). Thermal values of symmetrical parts of the body surface should be similar (Ammer, 2008; Uematsu et al., et al., 1988) with a small range of variation. This means that the normality of a healthy subject is the thermal symmetry.

As a result, the most common use of thermography in sport is the temperature comparison of our body's symmetrical parts to detect a possible thermal imbalance (Goodman et al, 1985; Vardasca, 2008). These differences could mean to be considered an injury or just a thermal impairment.

\subsubsection{IRT AS A TOOL TO MONITOR SKIN TEMPERATURE ALONG THE RECOVERY} PROCESS OF AN ANTERIOR CRUCIATE LIGAMENT SURGERY

Thermography has proven to be an effective tool in order to monitor rehabilitation processes. After ethics committee approval and written informed consent was obtained, twenty five people participated in this study located in San Carlos Clinical Hospital (age: $32.68 \pm 8.6$ years, weight: $62.3 \pm 21.6$ kilograms, height: $1.72 \pm 0.27$ meters, 23 men and 2 women) who were injured playing mainly soccer. All of them had undergone the same surgery and six-week rehabilitation program at the hospital. Thermograms of anterior and posterior views were registered with a FLIR infrared camera according to the protocol established by the International Academy of Clinical Thermology. Each leg was divided into anterior and posterior view in order to compare them to its contralateral limb.

A student $t$-test for related samples was performed. Most of the areas in P2 showed higher values of skin temperature $\left(T_{s k}\right)$. 
Most of the studies mentioned before are cross sectional. Nevertheless, not many longitudinal studies have been carried out with reference to thermal evolution over, at least, a year.

Therefore, one of the objectives of this longitudinal research was to compare the $T_{\text {sk }}$ between the injured and non-injured leg 18 months from rehabilitation. If thermal balance was recovered, thermograms should have not shown thermal asymmetries (Lahiri et al., 2012).

Reviewing the literature we found it interesting and relevant in practice to do this work on $\mathrm{ACL}$ rehabilitation. This work consists of 4 studies that compare the thermal status in different stages and between both legs. Figure 10 in study design shows a summary of the 4 studies.

1.3.4.1. Study 1. Thermal evolution of lower limbs during a rehabilitation process after Anterior Cruciate Ligament surgery: Summary

The aim of this study was to establish the probable thermal difference of the lower limbs between the beginning (P0) and the end (P1) of the anterior cruciate ligament $(A C L)$ rehabilitation process after surgery. The results showed significant temperature increases in the posterior thigh area between P0 and P1 of the rehabilitation process probably due to a compensatory mechanism. According to this, we can conclude that temperature of the posterior area of the injured and non-injured leg has increased from the first to the last day of the rehabilitation process.

1.3.4.2. Study 2. Quantification of thermal asymmetry at the beginning and at the end of rehabilitation after anterior cruciate ligament reconstruction: Summary The aim was to establish the skin thermal difference $\left(T_{\text {sk }}\right)$ between the injured and the non-injured leg in two stages: the beginning (P0) and the end (P1) of 
rehabilitation. We found significant temperature differences between the injured and non-injured leg in both stages of rehabilitation $(p<.01)$. On the one hand, the temperature of the injured leg is higher in the anterior view and the temperature of the non-injured leg is higher in the posterior view.

By the time the patients had recovered from the reconstruction, thermal imbalances should not be shown between symmetrical parts.

1.3.4.3. Study 3: Thermal evolution of lower limbs after one year and a half from Anterior Cruciate Ligament rehabilitation: Summary

The aim of this study was to establish the probable thermal difference of the lower limbs between the end of the anterior cruciate ligament $(A C L)$ rehabilitation process after reconstruction (P1) and 18 months later (P2).

Temperatures seem to be higher after a year and a half (P2). Future studies are needed to investigate whether these values will remain as the patient profile.

1.3.4.4. Study 4. Quantification of thermal asymmetry between the injured leg and the non-injured leg after 18 months from the rehabilitation: Summary

Thermography can be used to assess the skin thermal $\left(T_{s k}\right)$ difference between two symmetrical parts of the body. This study sought to compare the $T_{\text {sk }}$ between the injured and non-injured leg 18 months following rehabilitation (P2). After the rehabilitation, we found significant differences between the two legs $(p<.05)$, however, thermal values one year and a half later (P2) seemed to have normalized. No significant differences were found between the injured leg and the non-injured leg after one year and a half of the rehabilitation process. Therefore, patients seemed to have recovered from a thermal point of view. The highest difference recorded then was $0.11^{\circ} \mathrm{C}$. 
24 
2. HYPOTHESES AND OBJECTIVES 


\section{HYPOTHESES AND OBJECTIVES}

\subsection{HYPOTHESES}

The $T_{\text {sk }}$ of the legs varies along the rehabilitation of an ACL rupture measured by IRT.

\subsection{OBJECTIVE}

To study whether IRT can capture changes in $\mathrm{T}_{\text {sk }}$ over the recovery process.

\subsection{STUDY 1}

\subsubsection{HYPOTHESES}

The $T_{s k}$ of the legs is different before starting rehabilitation and when the rehabilitation has been completed.

\subsubsection{OBJECTIVES}

a) To determine the possible variation of $T_{\text {sk }}$ of the injured leg between two moments: before and after rehabilitation.

b) To determine the possible variation of $T_{s k}$ of the non-injured leg between two moments: before and after rehabilitation.

c) To study how the results reflect the recovery.

\subsection{STUDY 2}

\subsubsection{HYPOTHESES}

The $T_{\text {sk }}$ of the injured leg is not the same as the non-injured before and after the rehabilitation.

\subsubsection{OBJECTIVES}

a) To analyze the possible skin thermal difference between the injured and non-injured leg before rehabilitation.

b) To analyze the possible skin thermal difference between the injured and non-injured leg after rehabilitation 


\subsection{STUDY 3}

\subsubsection{HYPOTHESES}

The $T_{\text {sk }}$ of the legs is different after finishing the rehabilitation comparing with 18 months later.

\subsubsection{OBJECTIVES}

a) To investigate the possible variation of $T_{\text {sk }}$ of the injured leg between two moments: after rehabilitation and 18 months later

b) To investigate the possible variation of $T_{s k}$ of the non-injured leg between two moments: after rehabilitation and 18 months later

\subsection{STUDY 4}

\subsubsection{HYPOTHESES}

The $T_{\text {sk }}$ of the injured leg is not the same as the non-injured 18 months from the end of the rehabilitation.

\subsubsection{OBJECTIVES}

a) To determine the possible thermal difference between the injured and non-injured leg 18 months from the end of the rehabilitation. 
3. MATERIAL AND METHODS 


\section{METHODOLOGY}

\subsection{LITERATURE REVIEW METHODOLOGY}

The search engines Medline, Pubmed, ISI Web of knowledge, Sport Discus, Science Direct, EBESCO and googgle scholar were used to identify studies related with infrared thermography and others keywords. The most used keywords were a combination between a common keyword "infrared thermography or thermography or thermal imaging or thermology or thermal vision" and many other words used for this work, as for example "injury", "knee", "ACL", "rehabilitation", "sport", "influence factors", "surgery", "joint", "animal”, "cancer".

IRT has evolved in recent years and original papers have been published in the last 20 years, which were preferentially considered. The inclusion criteria for study selection were (1) literature written in English, (2) participants were human beings, and (3) skin temperature assessed by non-contact IRT. Other studies, which may have been missed in the original search, were also included by reviewing the bibliography of the found articles. A total of 1894 publications were indexed during the last 20 years according to the inclusion criteria.

\subsection{SAMPLE}

The access to the sample was possible thanks to the collaboration of the San Carlos Clinical Hospital and its Physiotherapist Department.

The total number of subjects was 34 , with 150 pictures analyzed. Nine subjects were excluded from the study due to lack of continuity or other associated serious injuries that could bias the study. Therefore, the final sample consisted of 25 Spanish subjects (age: $32.68 \pm 8.6$ years, weight: $62.3 \pm 21.6$ kilograms, height: $1.72 \pm 0.27$ meters, 23 men and 2 women) of which $92 \%$ were injured practicing sports, football, 
skiing and racket sports in most cases (Figure 8). The remaining $8 \%$ were injured in traffic accidents but also practiced exercise regularly. Subjects spent an average of 34.16 \pm 12.02 days from the date of the operation until the beginning of rehabilitation.

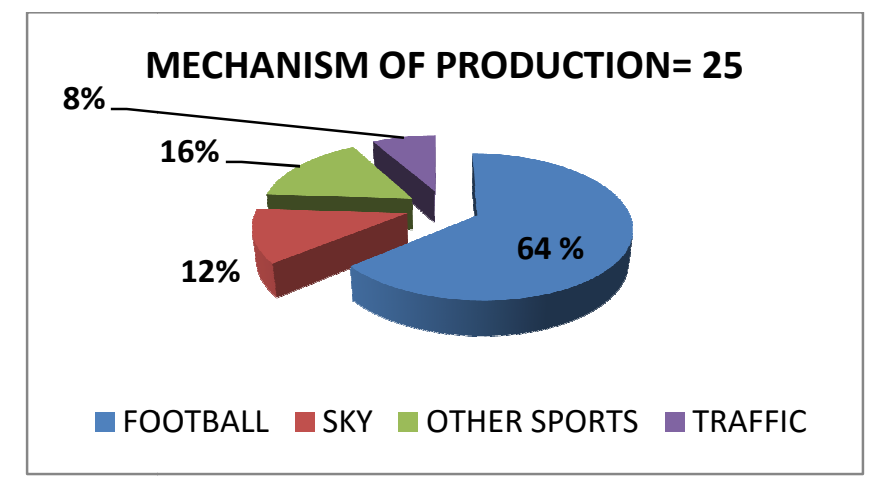

Figure 8.- Mechanism of production of injury of ACL of the subjects who participated in this study.

\subsection{EQUIPMENT}

\subsubsection{THERMOGRAPHIC EVALUATION EQUIPMENT}

Thermal images were recorded with a T335 FLIR infrared camera (FLIR Systems, Sweden). Table 2 shows the general characteristics of the thermographic camera used in the study (Figure 9):
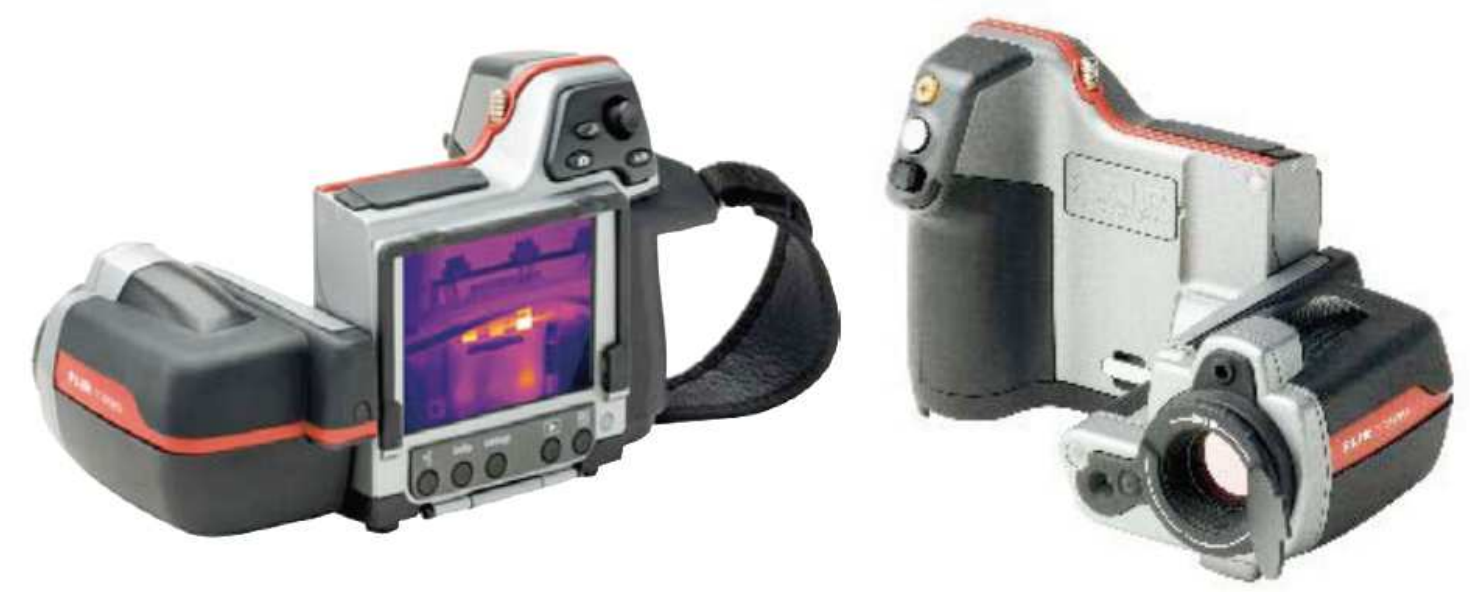

Figure 9.- T335 FLIR ${ }^{\circledR}$ infrared camera (FLIR ${ }^{\circledR}$ Systems, Sweden) 
Table 2.- General characteristics of IRT camera T335 (FLIR ${ }^{\circledR}$ Systems, Sweden)

\begin{tabular}{l|l}
\hline $\begin{array}{l}\text { Specifications of IRT camera T335 (FLIR } \\
\text { Imaging performance }\end{array}$ & Systems, Sweden) \\
IR Resolution & $320 \times 240$ pixels \\
Object temperature range & $7.5-13 \mu \mathrm{m}$ \\
Image frequency & $30 \mathrm{~Hz}$ \\
Thermal sensitivity / NETD & $50 \mathrm{mK}$ at $30^{\circ} \mathrm{C}$ \\
Spectral range & $7.5-13 \mu \mathrm{m}$ \\
Spatial resolution (IFOV) & $1.36 \mathrm{mrad}$ \\
Focal Plane Array (FPA) & Uncooled microbolometer \\
Measurement & $-20^{\circ} \mathrm{C}$ to $+650^{\circ} \mathrm{C}$ in 3 ranges: $-20^{\circ} \mathrm{C}$ to $+120^{\circ} \mathrm{C}$ or $0^{\circ} \mathrm{C}$ to \\
Object temperature range & $+350^{\circ} \mathrm{C}$ or $+200^{\circ} \mathrm{C}$ to $+650^{\circ} \mathrm{C}$ \\
& $\pm 2{ }^{\circ} \mathrm{Cor} 2 \%$ reading \\
\hline Accuracy &
\end{tabular}

\subsubsection{SOFTWARE EQUIPMENT}

Thermograms were analyzed with Therma CAM Reporter 8 software to extract the temperature data (maximum, minimum, average and standard deviations). The data were sorted and managed with Microsoft Excel 2007 and later were analyzed with SPSS for Windows v.15.0 (SPSS Worldwide Headquarters, Chicago, IL).

\subsubsection{ATMOSPHERIC REGISTRATION EQUIPMENT}

The environmental conditions of temperature, humidity and atmospheric pressure were registered with a portable weather station BAR908HG (Oregon Scientific).

Table 3.- General characteristics of the weather station, model BAR-908HG ${ }^{\circledR}$ (Oregon Scientific, Portland, Oregon)

Characteristics of the portable weather station, Oregon BAR-908-HG mode

Weight

Dimensions

Temperature

Humidity

Atmosphere pressure

Indicators

Others
376 grams.

$188 \times 120 \times 86 \mathrm{~mm}$. (height $\mathrm{x}$ width $\mathrm{x}$ depth) Interior $\left(-5 /+50^{\circ} \mathrm{C}\right)$

Interior and exterior ( $25-95 \%)$

Numeric value; $500-1050 \mathrm{mb} / \mathrm{hPa}$. Resolution: $1 \mathrm{mb} / \mathrm{hPa}$

Trends and comfort zones

-Evolution charts of the atmospheric pressure in the last 24 hours -Weather forecast with symbols 


\subsubsection{OTHER EQUIPMENT}

- A tripod Hama Omega Premium II (Hama Monheim, Germany) was used to hold the camera during the data collection.

- A "Roll up" of $125 \times 206 \mathrm{~cm}$ was used to obtain a homogeneous background behind the subjects.

- A "Step" Domyos 160 (Decathlon, France) with marks was used to fix the standing protocol position and raising $10 \mathrm{~cm}$ the subject from the floor surface.

\subsection{RESEARCHERS}

The rehabilitation protocol was designed by the staff of the Clinical Hospital San Carlos and his team of physical therapists and chiropractors which are explained ahead.

A thermography technician carried out the data collection and subsequent processing and interpretation.

\subsection{METHODOLOGY}

\subsubsection{STUDY DESIGN}

The study design was a longitudinal with a convenience sample of participants who had an $A C L$ injury and had to undergo a surgical intervention and the same rehabilitation process at the same chamber of the San Carlos Clinical Hospital (Madrid). Pictures of the anterior and posterior region of both legs were taken in three periods: Before starting rehabilitation (P0), a week after finishing rehabilitation (P1) and a 18 months after finishing rehabilitation (P2). Studies 1 and 2 are referred to the first period (P0-P1) and studies 3 and 4 to the second period (P1-P2). Figure 10 shows a summary of the study design. 


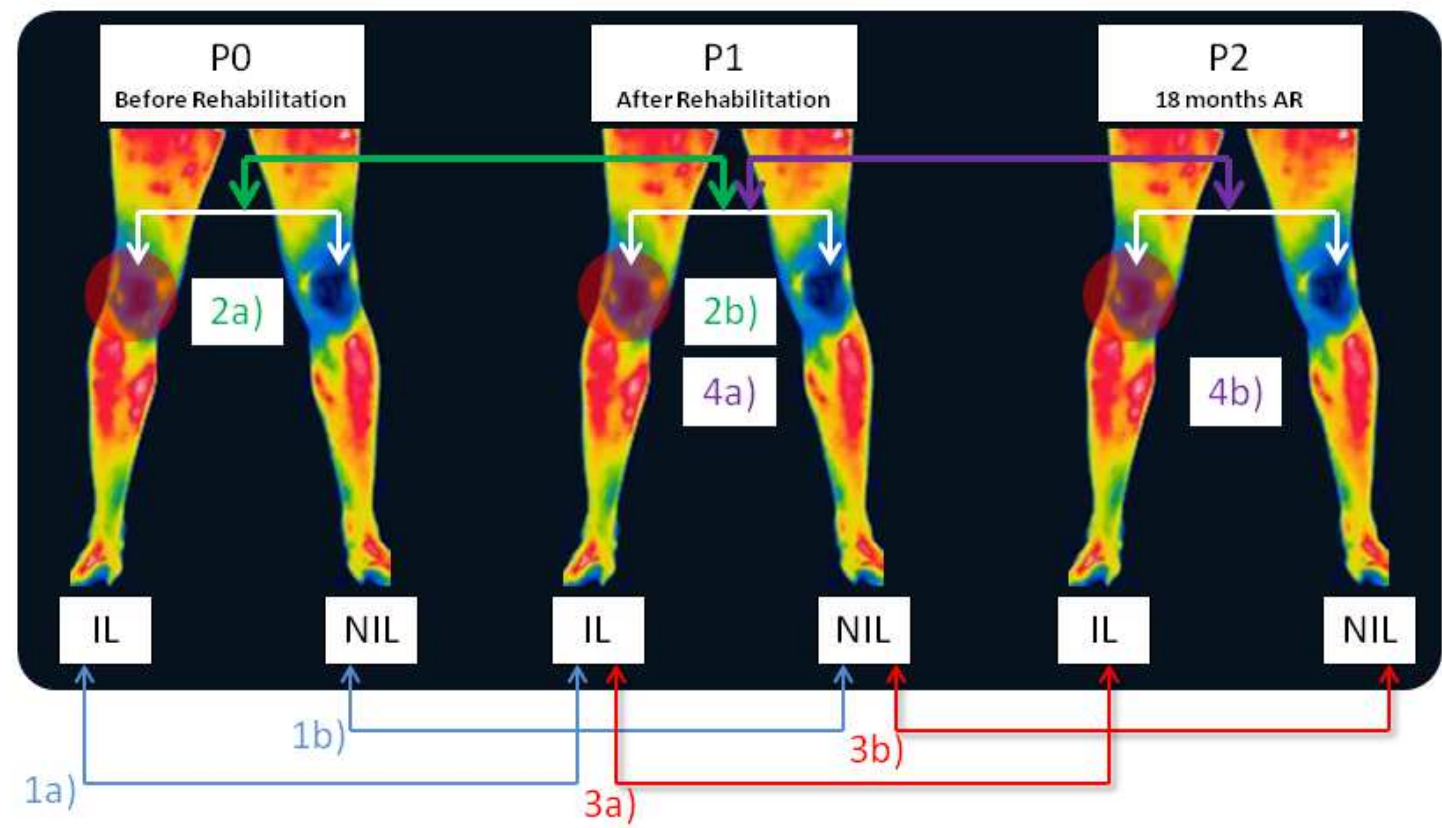
Study 1. a) $\Delta T_{T S K}(\stackrel{\circ}{ } \mathrm{C})\left(\mathrm{IL}_{\mathrm{p} 0}-\mathrm{IL}_{\mathrm{p} 1}\right)$
b) $\Delta \mathrm{T}_{\mathrm{TSK}}(\stackrel{\mathrm{o}}{ } \mathrm{C})\left(\mathrm{NIL}_{\mathrm{p} 0}-\mathrm{NIL}_{\mathrm{p} 1}\right)$
Study 2. a) $\Delta \mathrm{T}_{\mathrm{TSK}}(\stackrel{\mathrm{o}}{\mathrm{C}})\left(\mathrm{IL}_{\mathrm{p} 0}-\mathrm{NIL}_{\mathrm{po}}\right)$
b) $\Delta T_{T S K}(\stackrel{\circ}{\circ})\left(I_{p 1}-N I L_{p 1}\right)$
Study 3. a) $\Delta T_{T S K}($ oC $)\left(I L_{p 1}-I L_{p 2}\right)$
b) $\Delta T_{T S K}(\stackrel{\circ}{ })\left(N^{\prime} L_{p 1}-N I L_{p 2}\right)$
Study 4. a) $\Delta \mathrm{T}_{\mathrm{TSK}}(\stackrel{\mathrm{o}}{\mathrm{C}})\left(\mathrm{IL}_{\mathrm{p} 1}-\mathrm{NIL}_{\mathrm{p} 1}\right)$
b) $\Delta T_{T S K}(\stackrel{\circ}{ })\left(I_{p 2}-N L_{p 2}\right)$

Figure 10.- Summary of the 4 studies

\subsubsection{SESSION STRUCTURE}

Infrared pictures were always taken on Mondays (after the weekend) between 9:00 and 10:00 am. All evaluations took place when subjects arrived at the San Carlos Clinical Hospital Rehabilitation Center, not allowing them to start any exercise until they had completed the evaluation in order to obtain images of the subject in a complete state of rest.

Once the subject arrived to the hospital room, the acclimatization time, at least for 10 minutes, was respected before the thermographic evaluation (Bouzas Marins, et al., 2014). 
Afterwards, the subject exercised following the schedule hospital directions. This rutine was repeated five days per week for six weeks. Every session lasted around one hour per session.

\subsubsection{INFLUENCING FACTORS REGISTRATION}

The surface area of the measuring room was approximately $70 \mathrm{~m}^{2}$, with an average temperature of $21^{\circ} \mathrm{C} \pm 1.9^{\circ} \mathrm{C}$, always between the ideal values for thermographic studies in humans (Garagiola \& Giani, 1990; IACT, 2002; Ring \& Ammer, 2000).

The humidity can affect also to the data collection (Reinikainen \& Jaakkola, 2003) and also the atmospheric pressure, so that, remained stable during all the shots with average values of $56 \pm 2.3 \%$ (Zontak, et al., 1998) and $938 \pm 5 \mathrm{hPa}$, respectively.

At each evaluation different influencing factors (IACT, 2002; Ring \& Ammer, 2000) were registered (Appendix 1): the application of creams, massage or other treatment, sun bathing or a shower in the previous 8 hours, consumption of a big meal, coffee, smoking or alcohol in the previous six hours. In recommendations, patients accepted to avoid these factors in order not to affect the results of the study.

\subsubsection{THERMOGRAPHIC EVALUATION}

First of all, all the participants formally agreed to collaborate in the research and signed an informed consent. An Ethical Committee from the Technical University of Madrid (UPM) granted the permission to conduct this research with thermography on human beings in different populations (Appendix 2). Data were collected in San Carlos Clinical Hospital (Madrid).

Once they were at the hospital, at least ten minutes for acclimatization to environmental conditions in standing position were respected before each shot 
(Garagiola \& Giani, 1990; Zontak et al., 1998). Thermograms were taken by the same evaluator of both anterior and posterior views of the subject in all data collection (Figure 11).

The distance between the position of the patient and the camera for data collection was set at 2.5 meters (Garagiola \& Giani, 1990; IACT, 2002; Ring \& Ammer, 2000). A FLIR T-335 (FLIR Systems, Sweden) with a thermal sensitivity of $0.50 \mathrm{mK}$, an error of $\pm 2 \%$ of reading in ${ }^{\circ} \mathrm{C}$ and a resolution of $340 \times 260$ pixels, was used mounted on a tripod 0.9 meters high. Before the data collection, the camera was running for the same period of acclimatization than the subject, this provided time enough for the camera sensor to make a calibration. A fixed area of the black background was taken as the reference temperature. Images were obtained assuming a skin emissivity of 0.98 (Ring \& Ammer, 2012). The subject stood on a platform to raise him or her slightly from the ground level in front of a screen of $100 \times 200 \mathrm{~cm}$ to create a homogeneous background to avoid reflections behind the body. The platform had been painted footprints in order the subject could take the same position at every record.

For measurement, the subjects remained in their underwear, or in shorts held at the hips with tweezers. Two valid pictures (thermograms) were taken at each evaluation, an anterior and a posterior view of the lower limbs. Lee and Cohen distributed 6 areas of interest on each leg, 3 on the anterior view and 3 on the posterior view of the knee, thigh, leg and back (Lee \& Cohen, 2008). In our study we divided each of their areas into two areas (a medial and a lateral one), as explained below, in order to have data on the medial and lateral areas. Twelve regions of interest (ROI) were analyzed on each leg, 6 in the posterior view (PV) and 6 in the anterior view (AV) (Figure 11). The six areas are distributed in pairs along the lower member (Medial 
$=$ " $\mathrm{M}$ " and lateral = "L"). Two areas include the area of the knee (Knee Lateral "KL" and Knee Medial = "KM"), two in the thigh, (Thigh Lateral = "TL" and Thigh Medial = "TM") and the remaining two in the leg (Leg Lateral = "LL" and Leg Medial = "LM"). It was also considered whether the area was on the injured (I) or non-injured (NI) limb (Figure 11). After that, we have analyzed the global data of the anterior and posterior view as a whole area to get global results.
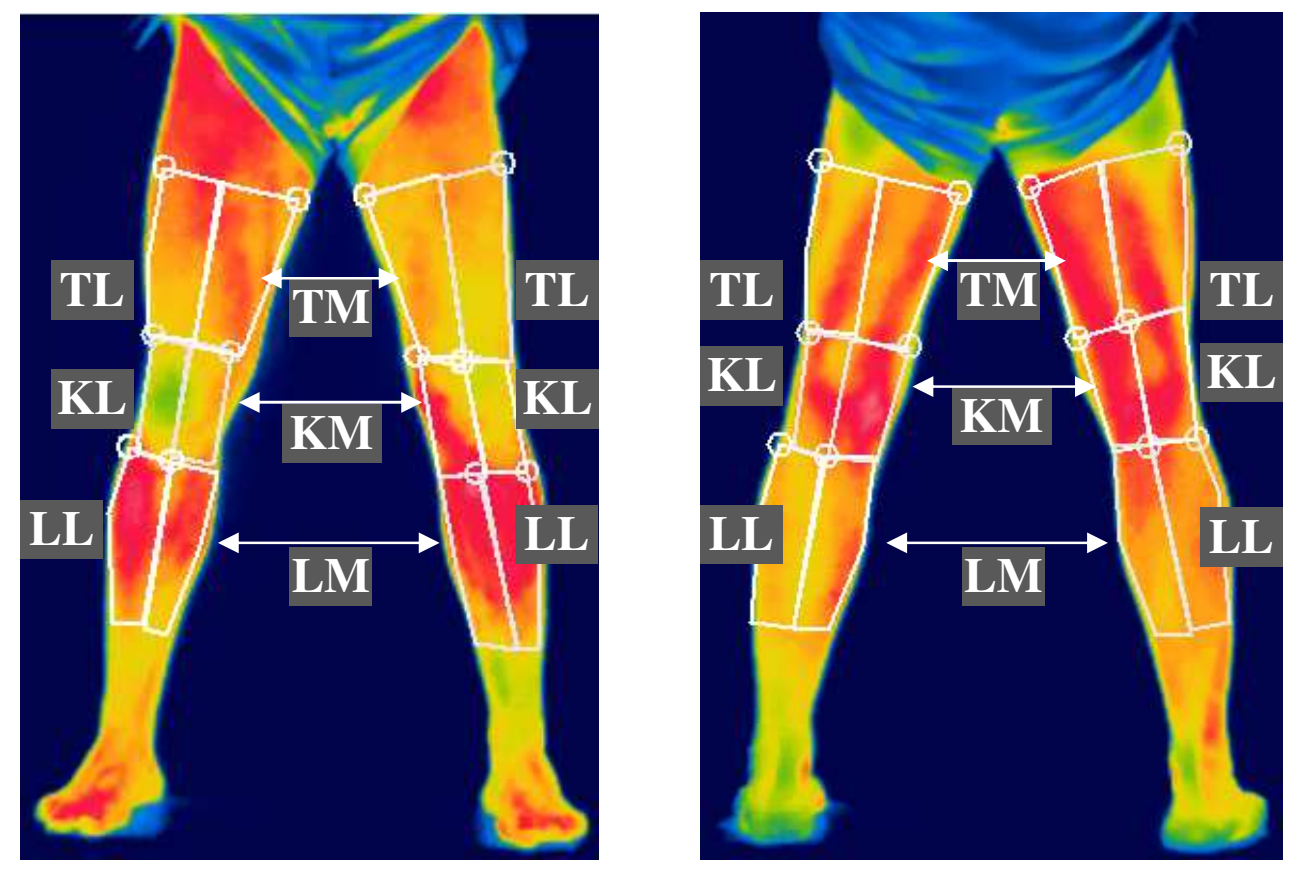

Figure 11.- Thermal images with the distribution of the 6 areas of the anterior view (left) and 6 areas of the posterior view (right): TL (Thigh Lateral), TM (Thigh Medial), LL (Leg Lateral), LM (Leg Medial), KL (Knee Lateral), KM (Knee Medial) of the Injured (I) and Non-Injured (NI) leg.

\subsubsection{HOSPITAL REHABILITATION PROGRAM}

In all cases the postoperative rehabilitation protocol of ACL (Appendix 3 ) was the same in each subject depending on the individual progress and the number of the 
week. If rehabilitation departs from this approach, the body reacts with adverse effects such as inflammation and pain (De Carlo, 2010; Paus, 1999).

Table 4.- Phases of rehabilitation related to the week of rehabilitation

\begin{tabular}{ccl}
\hline Phase & Week & \\
I & 1 & On crutches \\
I & 2 & Removal of 1 crutch \\
I & 3 & Removal of 2 crutches and cycle \\
II & 4 & Propioception \\
II & 5 & Resistance \\
II & 6 & Jumps \\
\hline
\end{tabular}

Subjects went to rehabilitation from Monday to Friday in more than $95 \%$ of times ( 5 days per week), and followed the directions from the physiotherapist, based on the diagnosis from traumatology. Both departments evaluated weekly the status of the patient. Patients did not take any standard medicine in connection with the rehabilitation. Once, the rehabilitation was finished, they started their daily life for the next 18 months.

Phase I (Table 4) focuses on restoring the range of motion, pain modulation, inflammatory control, modifying activities and gait training. Phase II is characterized by obtaining the full range of motion, adaptation to normal walking, increased strength and flexibility, cardiovascular conditioning if necessary, propioception and cycling. Phase III consists of functional returns to the previous level of activity. This phase includes a sport / occupational specific functional progression (Paus, 1999).

\subsubsection{WEEK 1- (Subject arrives on crutches and / or stabilizer knee brace)}

-Ice 20 minutes every two hours at home

-Exercises on the stretcher:

-Flexoextension of the Knee-length with wedge.

-Extension against resistance on the back of the knee (Stomp it). 
-Flexoextension on a stretcher sliding the leg.

-Flexoextension on a sit position with legs dangling extension at $90^{\circ}$.

-Electrostimulation of quadriceps, especially the vastus (Megasonic 900).

-Walking barefoot on mats in parallels.

-In Case of severe inflammation; Magnet therapy. Maximum 20 sessions.

3.5.5.2. WEEK 2- (Removal of orthotics if any and one crutch)

-Same procedure as week 1 and:

-Squats with back against the wall (possible range not exceeding 90).

-"Estape” (Up 2 steps and lower them back).

-Stairs.

-Hamstrings strengthening with Theraband (resistance adapted to each subject).

-Walking barefoot on mats without parallel.

-Manual processing of passive flexion and extension of knee forced to the limit.

3.5.5.3. WEEK 3-( Final withdrawal of the 2 crutches or any external help)

-Same procedure as week 2 and:

-Propioception exercises:

-Wouller plate with parallels.

-With ball.

-Static bicycle with lower seat and within the grades that the knee allows.

3.5.5.4. WEEK 4- (Propioception)

-Same procedure as week 3 and:

-Propioception:

-Balance With a foot (one foot).

-Add Harmonic movements of the free leg (non-injured) to unbalance. 
-To adopt and enforce knee flexion from the kneeling position (trend to sit on your heels)

\subsubsection{WEEK 5- (Resistance)}

-Same procedure as week 4 and:

-Increase Progressively the number of repetitions and the resistance of each exercise -Propioception in Wouller plate without parallel and external destabilization.

\subsubsection{WEEK 6- (Jumps)}

-Same procedure as week 5 and:

-Jumps on mats with falling in semiflexion.

\subsection{STATISTICAL ANALISYS}

Firstly, we divided each leg into twelve regions of interest (ROI). Average, maximum temperature and standard deviation of each area were calculated with Therma CAM Reporter 8 (Tables 5 and 6). Secondly, data were arranged and managed with Microsoft Excel 2007 and later analyzed with SPSS for Windows v.15.0 (SPSS Worldwide Headquarters, Chicago, IL). The sample was tested for normality using the Shapiro-Wilk test and for homogeneity of variances using the F-test. Once the normality was checked, descriptive data were calculated and the Student's $t$-test for related samples was performed to establish differences in the variables between the injured and non-injured leg with a confidence level of $95 \%$.

\subsubsection{SELECTION OF REGION OF INTEREST (ROI)}

Although ThermaCam Reporter 8 is able to get temperatures of so many ROIS as we want, the quantity of regions selected for statiscal analysed were few in order to reduce the quantity of information and focus on the most relevant ROI. Figure 1 shows 
the ROls selected. Afterwards, related ROls were joined for a better and easier understanding, as for example in just three regions (Thigh, knee, leg). 
4. RESULTS

43 
44 


\section{RESULTS}

Results of studies 1 and 3 are related to the thermal evolution between 2 periods. However, studies 2 and 4 quantify the thermal asymmetry between the injured leg and non-injured leg within two time points.

\subsection{STUDY I}

\subsubsection{ANALYSIS OF TEMPERATURE}

Table 5 shows the average of the temperatures of different injured leg areas registered prior to the rehabilitation program. Based on the table, before statistical analysis, we can see that most differences in temperature between the first week of rehabilitation (P0) and the last week of rehabilitation (P1) relate to a higher temperature of the leg on $\mathrm{PO}$. This would mean that on $\mathrm{PO}$ the values of temperature seem to be higher than the values on P1. In the average data we observe the maximum difference of $0.57^{\circ} \mathrm{C}$ between the same side areas of the anterior thigh medial (A-TM). We can appreciate a decrease in temperature from P0 to $\mathrm{P} 1$ in other anterior areas as thigh lateral $(A-T L)$, knee lateral $(A-K L)$ and knee medial $(A-K M)$. In the posterior view the biggest decrease occurs between the thigh medial areas (P-TM). There are only 3 areas where temperature on $\mathrm{P} 1$ is higher than on $\mathrm{P} 0$, but the differences are less than $0.1^{\circ} \mathrm{C}$, so that it means that the temperature is very similar in both times. In the maximum data the biggest different correspond also to the anterior thigh medial $(\mathrm{A}-\mathrm{TM})$ with $0.55^{\circ} \mathrm{C}$. As we can check in the table the other anterior areas behaves similar than with the average data. However, the posterior view shows that in some areas (P-LL and P-LM) the temperature between P0 and P1 has increased over $0.2^{\circ} \mathrm{C}$ 
Table 5.- Injured Leg. Average and maximum values of the anterior (A-) and posterior (P-) view: TL (Thigh Lateral), TM (Thigh Medial), LL (Leg Lateral), LM (Leg Medial), KL (Knee Lateral), KM (Knee Medial)

\begin{tabular}{|c|c|c|c|c|c|c|c|c|c|c|}
\hline \multirow{3}{*}{$\begin{array}{l}\text { Regions of Interest } \\
\text { (R.O.I) Injured Leg }\end{array}$} & \multicolumn{5}{|c|}{ AVERAGE TEMPERATURES } & \multicolumn{5}{|c|}{ MAXIMUM TEMPERATURES } \\
\hline & \multicolumn{2}{|c|}{ PO } & \multicolumn{2}{|c|}{ P1 } & \multirow[b]{2}{*}{$\Delta \mathrm{T}_{\mathrm{sk}}$} & \multicolumn{2}{|c|}{ PO } & \multicolumn{2}{|c|}{ P1 } & \multirow[b]{2}{*}{$\Delta \mathrm{T}_{\mathrm{sk}}$} \\
\hline & $\mathrm{x}$ & SD & $\mathrm{x}$ & SD & & $\mathrm{x}$ & SD & $\mathrm{x}$ & SD & \\
\hline A-TL & 29.79 & 1.15 & 29.40 & 1.29 & 0.39 & 31.00 & 1.08 & 30.58 & 0.97 & 0.41 \\
\hline A-TM & 29.62 & 1.34 & 29.06 & 1.27 & 0.57 & 31.26 & 1.23 & 30.71 & 0.90 & 0.55 \\
\hline A-LL & 31.53 & 1.01 & 31.59 & 0.75 & -0.06 & 32.98 & 0.92 & 32.94 & 0.62 & 0.04 \\
\hline A-LM & 31.31 & 1.13 & 31.25 & 0.85 & 0.06 & 32.94 & 1.00 & 32.77 & 0.68 & 0.17 \\
\hline A-KL & 30.24 & 1.36 & 30.00 & 0.92 & 0.24 & 32.20 & 1.19 & 32.00 & 0.77 & 0.20 \\
\hline A-KM & 30.54 & 1.11 & 30.14 & 0.90 & 0.40 & 32.37 & 1.13 & 32.04 & 0.81 & 0.33 \\
\hline P-TL & 30.22 & 1.38 & 30.04 & 1.13 & 0.18 & 31.28 & 1.17 & 31.21 & 0.91 & 0.07 \\
\hline P-TM & 30.65 & 1.27 & 30.32 & 1.07 & 0.33 & 31.76 & 1.09 & 31.59 & 0.91 & 0.17 \\
\hline P-LL & 30.76 & 0.95 & 30.86 & 1.15 & -0.09 & 31.92 & 0.88 & 32.11 & 1.05 & -0.20 \\
\hline P-LM & 30.94 & 0.84 & 31.02 & 1.16 & -0.07 & 31.98 & 0.88 & 32.24 & 1.08 & -0.26 \\
\hline P-KL & 31.08 & 0.98 & 30.92 & 1.10 & 0.16 & 32.53 & 0.90 & 32.44 & 1.00 & 0.08 \\
\hline P-KM & 31.16 & 0.98 & 30.99 & 0.91 & 0.18 & 32.54 & 0.82 & 32.40 & 0.85 & 0.13 \\
\hline
\end{tabular}

On table 5, we can see that most differences in temperature between the first and the last week relate to a higher temperature of the leg on P0. In the average data we observe the maximum difference of $0.44^{\circ} \mathrm{C}$ between the same side areas of the anterior thigh medial (A-TM). We can observe a decrease in temperature from P0 to P1 in other anterior areas as thigh lateral (A-TL). In the posterior view the biggest decrease occurs between the thigh lateral and medial areas (P-TM, P-TL). There are 2 areas where the temperature $\mathrm{ON} P 1$ is higher than on $\mathrm{P} 0$, but the difference is less than $0.1^{\circ} \mathrm{C}$. In the maximum data the biggest difference corresponds also to the anterior thigh lateral $(\mathrm{A}-\mathrm{TL})$ with $0.46^{\circ} \mathrm{C}$ while the thigh medial difference decreased $0.08^{\circ} \mathrm{C}$. However, the posterior view shows that in both knee and leg areas the temperature on the $\mathrm{P} 1$ was higher than on $\mathrm{P} 0$.

Table 6 shows the average of the temperatures of different non-injured leg areas registered prior to the rehabilitation program (PO). 
Table 6.- Non-injured Leg. Average values of the anterior ( $\mathrm{A}-$ ) and posterior ( $\mathrm{P}-$ ) view: TL (Thigh Lateral), TM (Thigh Medial), LL (Leg Lateral), LM (Leg Medial), KL (Knee Lateral), KM (Knee Medial)

\begin{tabular}{|c|c|c|c|c|c|c|c|c|c|c|}
\hline \multirow{3}{*}{$\begin{array}{c}\text { Regions of Interest } \\
\text { (R.O.I) } \\
\text { Non-injured leg }\end{array}$} & \multicolumn{5}{|c|}{ AVERAGE TEMPERATURES } & \multicolumn{5}{|c|}{ MAXIMUM TEMPERATURES } \\
\hline & \multicolumn{2}{|c|}{ PO } & \multicolumn{2}{|c|}{$\mathrm{P} 1$} & \multirow[b]{2}{*}{$\Delta \mathrm{T}_{\mathrm{sk}}$} & \multicolumn{2}{|c|}{ PO } & \multicolumn{2}{|c|}{ P1 } & \multirow[b]{2}{*}{$\Delta \mathrm{T}_{\mathrm{sk}}$} \\
\hline & $X$ & SD & $X$ & SD & & $X$ & SD & $X$ & SD & \\
\hline A-TL & 30.28 & 1.10 & 29.92 & 1.19 & 0.36 & 31.45 & 0.96 & 30.99 & 0.89 & 0.46 \\
\hline A-TM & 30.11 & 1.27 & 29.67 & 1.31 & 0.44 & 31.51 & 1.09 & 31.44 & 2.73 & 0.08 \\
\hline A-LL & 31.67 & 0.89 & 31.77 & 0.82 & -0.10 & 32.77 & 0.85 & 32.89 & 0.65 & -0.12 \\
\hline A-LM & 31.18 & 1.10 & 31.13 & 1.08 & 0.05 & 32.48 & 1.08 & 32.32 & 0.80 & 0.16 \\
\hline$A-K L$ & 29.38 & 0.99 & 29.28 & 1.09 & 0.09 & 31.44 & 1.08 & 31.28 & 0.94 & 0.16 \\
\hline A-KM & 29.75 & 1.02 & 29.56 & 1.17 & 0.18 & 31.21 & 0.90 & 31.17 & 2.14 & 0.04 \\
\hline P-TL & 30.44 & 1.29 & 30.11 & 1.21 & 0.33 & 31.71 & 1.07 & 31.56 & 1.04 & 0.15 \\
\hline P-TM & 31.04 & 1.40 & 30.84 & 1.31 & 0.20 & 32.24 & 1.09 & 32.02 & 1.04 & 0.22 \\
\hline P-LL & 31.19 & 0.92 & 31.21 & 1.12 & -0.02 & 32.10 & 0.99 & 32.30 & 1.04 & -0.20 \\
\hline P-LM & 31.36 & 0.91 & 31.32 & 1.07 & 0.04 & 32.19 & 0.88 & 32.32 & 0.98 & -0.14 \\
\hline P-KL & 31.34 & 0.89 & 31.30 & 1.12 & 0.04 & 32.68 & 0.75 & 32.77 & 0.84 & -0.08 \\
\hline P-KM & 31.40 & 0.98 & 31.19 & 1.07 & 0.21 & 32.59 & 0.88 & 32.68 & 0.91 & -0.09 \\
\hline
\end{tabular}

4.1.2. THERMOGRAPHIC PROFILE OF AN ACL INJURY BEFORE AND AFTER THE REHABILITATION PROGRAM

Table below shows a summary of the average values obtained within 3 areas per view. The areas medial and lateral of each anatomical part have been joined for a better statistic analysis.

Table 7.- Average temperature $\left({ }^{\circ} \mathrm{C}\right)$ difference for the thermal profile of the postoperative period of the $A C L$ between $\mathrm{P} 0$ and $\mathrm{P} 1$.

\begin{tabular}{|c|c|c|c|c|c|c|c|}
\hline & \multirow[b]{2}{*}{ Rehab Week } & \multicolumn{3}{|c|}{ ANTERIOR VIEW (AV) } & \multicolumn{3}{|c|}{ POSTERIOR VIEW (PV) } \\
\hline & & Thigh & Knee & Leg & Thigh & Knee & Leg \\
\hline \multirow{3}{*}{ INJURED LEG } & PO & 29.71 & 30.39 & 31.42 & 30.40 & 31.12 & 30.85 \\
\hline & P1 & 29.23 & 30.10 & 31.42 & 30.18 & 30.95 & 30.94 \\
\hline & $\Delta \mathrm{T}_{\text {sk }} \mathrm{PO}-\mathrm{P} 1$ & 0.48 & 0.29 & 0 & 0.22 & 0.17 & -0.09 \\
\hline \multirow{3}{*}{ NON-INJURED LEG } & PO & 30.19 & 29.56 & 31.42 & 30.74 & 31.37 & 31.28 \\
\hline & P1 & 29.80 & 29.42 & 31.45 & 30.48 & 31.25 & 31.27 \\
\hline & $\Delta \mathrm{T}_{\mathrm{sk}} \mathrm{PO}-\mathrm{P} 1$ & 0.39 & 0.14 & -0.03 & 0.26 & 0.12 & 0.01 \\
\hline
\end{tabular}


In the anterior view the most relevant value was $\left(t_{24}=1.975, p=.06\right)$ between the thigh lateral areas evolution, so there were no significant changes in the temperature between $\mathrm{P} 0$ and $\mathrm{P} 1$ in any of the areas. But as we can see above in the table 3 we find $0.48^{\circ} \mathrm{C}$ of difference between $\mathrm{P} 0$ and $\mathrm{P} 1$.

In the posterior view the most relevant value was $\left(t_{24}=1.087 ; p=.28\right)$ between the medial thighs, so there were no significant changes in the temperature between P0 and P1.

As we can detect the temperature difference within the thermograms and the body behaves with global responses, especially in the legs, we think it is useful to reduce the areas for a more global view and only focus in the maximal averages as they give us the hot spots of the injury and they are which cause pain. Then we simplified the areas in "injured leg anterior view", "injured leg posterior view", "noninjured leg anterior view", "non-injured leg posterior view".

Table 8.- Maximum temperature $\left({ }^{\circ} \mathrm{C}\right)$ differences between the P0 and P1. $\left({ }^{*} \mathrm{p}<0.05\right.$

\begin{tabular}{|c|c|c|c|c|c|}
\hline & & \multicolumn{2}{|c|}{ ANTERIOR VIEW } & \multicolumn{2}{|c|}{ POSTERIOR VIEW } \\
\hline & & $x$ & SD & $x$ & SD \\
\hline \multirow{3}{*}{ INJURED LEG } & PO & 32.17 & 0.93 & 31.90 & 0.88 \\
\hline & P1 & 31.95 & 0.76 & 32.31 & 0.78 \\
\hline & $\Delta \mathrm{T}_{\mathrm{sk}}$ & 0.22 & & $-0.42 *$ & \\
\hline \multirow{3}{*}{$\begin{array}{l}\text { NON-INJURED } \\
\text { LEG }\end{array}$} & PO & 31.77 & 0.90 & 32.14 & 0.90 \\
\hline & P1 & 32.70 & 0.80 & 32.70 & 0.65 \\
\hline & $\Delta \mathrm{T}_{\text {sk }}$ & $0.07^{\circ} \mathrm{C}$ & & $-0.56^{\circ} \mathrm{C}^{* *}$ & \\
\hline
\end{tabular}

The $t$ test for related samples shows that there were significant changes in maximum temperatures between $\mathrm{PO}$ and $\mathrm{P} 1$ and both in the injured leg and in the noninjured leg; $t_{24}=-2.24(p<0.034)$ and $t_{24}=-3.33(p<0.003)$ respectively. In the anterior 
view however, no significant differences were found $t_{24}=1.10 ;(p>0.05)$. As can be seen in the case of the non-injured leg this difference was higher (Table 3).

\subsection{STUDY II}

Figure 12 depicts the temperature differences between the injured and noninjured leg in the anterior and posterior view, between the maximum temperature (Table 9) and average temperature (Table 10). Maximums show the peaks of temperature.

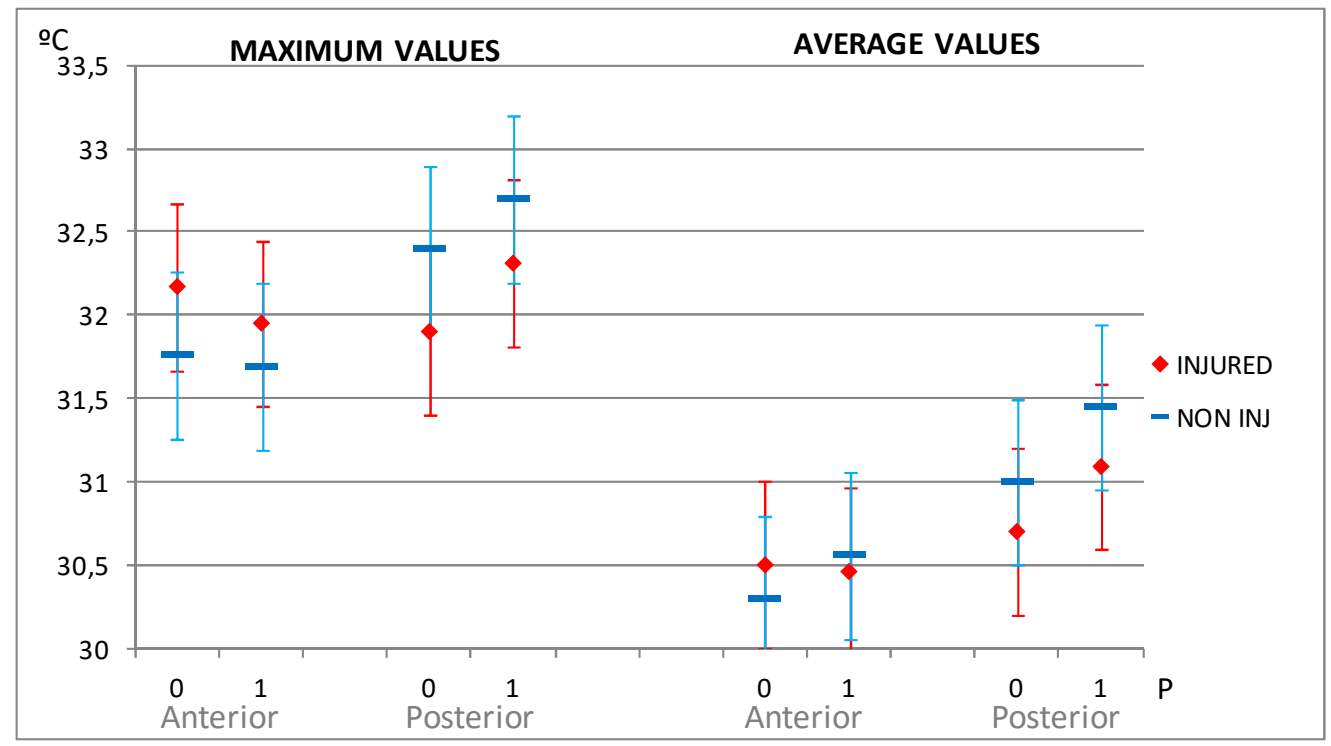

Figure 12.- Maximum and average values of temperature of the injured and noninjured leg on Po and P1.

Each view (anterior or posterior) has been compared to its contralateral at the same stage.

\subsubsection{MAXIMUM TEMPERATURES. ANTERIOR VIEW}

On P0 and on P1 we found a significantly higher temperature difference in the injured leg than in the non-injured $l e g, 0.41^{\circ} \mathrm{C}$ and $0.2^{\circ} \mathrm{C},\left(t_{24}=3.642, p=.001\right)$ and $\left(t_{24}=2.558, p=.017\right)$, respectively. 


\subsubsection{MAXIMUM TEMPERATURES. POSTERIOR VIEW}

In the posterior area the opposite effect occurred. On P0 and P1 the temperature of the non-injured leg was significantly higher than the temperature of the injured leg, $\left(t_{24}=-4.348, p<.001\right)$ and $\left(t_{24}=-5.378 ; p<.001\right)$, respectively.

Table 9.- Mean of the maximum temperature of the anterior and posterior views $*(p<.01) * *(p<.05)$

\begin{tabular}{|c|c|c|c|c|c|c|c|c|c|}
\hline & & \multirow[t]{2}{*}{$P$} & \multicolumn{2}{|c|}{ INJURED } & \multicolumn{2}{|c|}{ NON INJ } & \multirow[t]{2}{*}{$\Delta T_{\text {sk }}$} & \multirow[t]{2}{*}{$t_{24}$} & \multirow[t]{2}{*}{$p$} \\
\hline & & & $x$ & SD & $x$ & SD & & & \\
\hline \multirow{4}{*}{$\begin{array}{l}\text { MAXIMUM } \\
\text { VALUES }\end{array}$} & \multirow{2}{*}{ AV } & 0 & 32.17 & 0.93 & 31.76 & 0.90 & $0.41^{*}$ & 3.542 & .001 \\
\hline & & 1 & 31.90 & 0.75 & 31.70 & 0.80 & $0.20 * *$ & 2.558 & .017 \\
\hline & \multirow{2}{*}{ PV } & 0 & 31.90 & 0.88 & 32.40 & 0.90 & $-0.50 *$ & -4.348 & .000 \\
\hline & & 1 & 32.31 & 0.77 & 32.69 & 0.65 & $-0.38 *$ & -5.378 & .000 \\
\hline
\end{tabular}

\subsubsection{AVERAGE TEMPERATURES. ANTERIOR VIEW}

We did not find significant differences in temperature between both legs ( $p>.05)$, either in P0 $\left(t_{24}=1.829, p=.08\right)$ or in $P 1\left(t_{24}=0.882, p=.386\right)$.

\subsubsection{AVERAGE TEMPERATURES: POSTERIOR VIEW}

In contrast, the average data of the posterior view pointed out that the noninjured leg was warmer than the injured leg. On PO, the difference was of $0.3^{\circ} \mathrm{C}\left(\mathrm{t}_{24}=-\right.$ $6.542, p<.001)$, as well as on $\mathrm{P} 1\left(\mathrm{t}_{24}=-7.268, \mathrm{p}<.001\right)$.

Table 10.- Mean of the average temperature of the anterior and posterior views $*(p<.01)$

\begin{tabular}{|c|c|c|c|c|c|c|c|c|c|}
\hline & & \multirow[t]{2}{*}{$P$} & \multicolumn{2}{|c|}{ INJURED } & \multicolumn{2}{|c|}{ NON INJ } & \multirow{2}{*}{$\Delta T_{\text {sk }}$} & \multirow[t]{2}{*}{$t_{24}$} & \multirow[t]{2}{*}{$p$} \\
\hline & & & $x$ & SD & $x$ & SD & & & \\
\hline \multirow{4}{*}{$\begin{array}{l}\text { AVERAGE } \\
\text { VALUES }\end{array}$} & \multirow{2}{*}{ AV } & 0 & 30.50 & 0.70 & 30.30 & 0.30 & 0.20 & 1.829 & .080 \\
\hline & & 1 & 30.46 & 0.84 & 30.55 & 1.01 & -0.09 & 0.882 & .386 \\
\hline & \multirow{2}{*}{ PV } & 0 & 30.70 & 1.02 & 31.00 & 1.02 & $-0.30 *$ & -6.542 & .000 \\
\hline & & 1 & 31.10 & 0.82 & 31.40 & 0.79 & $-0.30 *$ & -7.268 & .000 \\
\hline
\end{tabular}




\subsection{STUDY III}

\subsubsection{ANALYSIS OF TEMPERATURE}

Table 11 shows the means data of the average and maximum temperatures of the injured leg areas. Based on data, we can note that most of the results are related to a higher temperature of the leg 18 months after the end of the rehabilitation. Consequently, results show that in $\mathrm{P} 2$, temperature values seem to be higher than in P1. In fact, table 11 shows many significant differences in both average and maximum temperatures $(p<0.05$ and $p<0.01)$ in all the areas but in the anterior medial knee $(A-$ $\mathrm{KM})$, where we can observe that maximum values have significantly decreased and the anterior lateral knee $(\mathrm{A}-\mathrm{KL})$, where the temperature has decreased as well (but not significantly).

Table 11.- Injured leg-Average values of the anterior (A-) and posterior ( $\mathrm{P}-$ ) view: TL (thigh lateral), TM (thigh medial), LL (leg lateral), LM (leg medial), KL (knee lateral), KM (knee medial). $(* p<.05 * * p<.01)$

\begin{tabular}{|c|c|c|c|c|c|c|c|c|c|c|}
\hline \multirow{3}{*}{$\begin{array}{l}\text { Regions of Interest (R.O.I) } \\
\text { Injured Leg }\end{array}$} & \multicolumn{5}{|c|}{ AVERAGE TEMPERATURES $\left({ }^{\circ} \mathrm{C}\right)$} & \multicolumn{5}{|c|}{ MAXIMUM TEMPERATURES $\left({ }^{\circ} \mathrm{C}\right)$} \\
\hline & \multicolumn{2}{|c|}{ P1 } & \multicolumn{2}{|c|}{ P2 } & \multirow[b]{2}{*}{$\Delta \mathrm{T}_{\mathrm{sk}}$} & \multicolumn{2}{|c|}{ P1 } & \multicolumn{2}{|c|}{ P2 } & \multirow[b]{2}{*}{$\Delta \mathrm{T}_{\mathrm{sk}}$} \\
\hline & $x$ & SD & $\mathrm{x}$ & SD & & $\mathrm{x}$ & SD & $\mathrm{x}$ & SD & \\
\hline A-TL & 29.34 & 1.29 & 30.70 & 1.20 & $-1.36^{* *}$ & 30.58 & 0.97 & 31.78 & 1.14 & $-1.2^{* *}$ \\
\hline A-TM & 29.06 & 1.27 & 30.70 & 1.30 & $-1.64^{* *}$ & 30.71 & 0.90 & 31.56 & 1.17 & $-0.85^{* *}$ \\
\hline$A-L L$ & 31.59 & 0.74 & 32.20 & 1.10 & $-0.61 * *$ & 32.94 & 0.62 & 33.42 & 1.13 & $-0.48^{*}$ \\
\hline A-LM & 31.25 & 0.84 & 31.70 & 1.20 & -0.45 & 32.76 & 0.67 & 33.23 & 1.16 & -0.47 \\
\hline$A-K L$ & 30.00 & 0.90 & 29.96 & 1.43 & 0.04 & 32.00 & 0.77 & 31.70 & 1.33 & 0.30 \\
\hline A-KM & 30.14 & 0.89 & 30.21 & 1.36 & -0.07 & 32.04 & 0.81 & 31.52 & 1.21 & $0.52^{*}$ \\
\hline P-TL & 30.04 & 1.13 & 31.54 & 1.27 & $-1.50 * *$ & 31.21 & 0.91 & 32.47 & 1.12 & $-1.26^{* *}$ \\
\hline P-TM & 30.32 & 1.07 & 31.76 & 1.16 & $-1.44 * *$ & 31.59 & 0.91 & 32.73 & 1.07 & $-1.14^{* *}$ \\
\hline P-LL & 30.85 & 1.15 & 31.98 & 1.25 & $-1.13^{* *}$ & 32.11 & 1.05 & 32.99 & 1.29 & $-0.88^{* *}$ \\
\hline P-LM & 31.01 & 1.15 & 31.98 & 1.17 & $-0.97^{* *}$ & 32.24 & 1.08 & 32.86 & 1.13 & $-0.62^{* *}$ \\
\hline $\mathrm{P}-\mathrm{KL}$ & 30.92 & 1.10 & 32.04 & 1.06 & $-1.12 * *$ & 32.44 & 1.00 & 33.14 & 0.96 & $-0.7^{* *}$ \\
\hline P-KM & 30.99 & 0.91 & 32.09 & 1.00 & $-1.1^{* *}$ & 32.40 & 0.85 & 33.20 & 0.92 & $-0.8^{* *}$ \\
\hline
\end{tabular}

Table 12 shows the means data of the average and maximum temperatures of the non-injured leg areas. According to the table, the non-injured leg has suffered a 
temperature enhancement from P1 to P2 in every area. Statistically significant changes were obtained in every area of average temperatures and in most of the areas of maximum temperatures (anterior and posterior views).

Table 12.- Non-injured leg. Average values of the anterior ( $\left.\mathrm{A}^{-}\right)$and posterior ( $\left.\mathrm{P}_{-}\right)$view: TL (thigh lateral), TM (thigh medial), LL (leg lateral), LM (leg medial), KL (knee lateral), KM (knee medial). $\left({ }^{*} p<.05 * * p<.01\right)$

\begin{tabular}{|c|c|c|c|c|c|c|c|c|c|c|}
\hline \multirow{3}{*}{$\begin{array}{l}\text { Regions of Interest } \\
\text { (R.O.I) Non-injured leg }\end{array}$} & \multicolumn{5}{|c|}{ AVERAGE TEMPERATURES $\left({ }^{\circ} \mathrm{C}\right)$} & \multicolumn{5}{|c|}{ MAXIMUM TEMPERATURES $\left({ }^{\circ} \mathrm{C}\right)$} \\
\hline & \multicolumn{2}{|c|}{$\mathrm{P} 1$} & \multicolumn{2}{|c|}{$\mathrm{P} 2$} & \multirow[b]{2}{*}{$\Delta \mathrm{T}_{\mathrm{sk}}$} & \multicolumn{2}{|c|}{ P1 } & \multicolumn{2}{|c|}{ P2 } & \multirow[b]{2}{*}{$\Delta \mathrm{T}_{\mathrm{sk}}$} \\
\hline & $x$ & SD & $x$ & SD & & $x$ & SD & $x$ & SD & \\
\hline A-TL & 29.92 & 1.19 & 30.87 & 1.19 & $-0.95^{* *}$ & 30.98 & 0.88 & 31.92 & 1.13 & $-0.94 * *$ \\
\hline A-TM & 29.67 & 1.31 & 31.98 & 1.29 & $-2.31^{* *}$ & 31.44 & 2.70 & 31.98 & 1.29 & -0.54 \\
\hline$A-L L$ & 31.77 & 0.82 & 32.24 & 1.09 & $-0.47^{*}$ & 32.90 & 0.64 & 33.21 & 1.01 & -0.31 \\
\hline A-LM & 31.13 & 1.08 & 31.76 & 1.25 & $-0.63^{*}$ & 32.32 & 0.80 & 33.04 & 1.06 & $-0.72 * *$ \\
\hline$A-K L$ & 29.28 & 1.09 & 29.96 & 1.41 & $-0.68^{*}$ & 31.28 & 0.94 & 31.78 & 1.26 & -0.50 \\
\hline A-KM & 29.56 & 1.17 & 30.34 & 1.53 & $-0.78^{*}$ & 31.17 & 2.13 & 31.67 & 1.33 & -0.50 \\
\hline P-TL & 30.11 & 1.21 & 31.59 & 1.24 & $-1.48^{* *}$ & 31.56 & 1.04 & 32.60 & 1.13 & $-1.04 * *$ \\
\hline P-TM & 30.84 & 1.31 & 31.94 & 1.18 & $-1.1^{* *}$ & 32.02 & 1.04 & 32.81 & 1.10 & $-0.79 * *$ \\
\hline P-LL & 31.21 & 1.12 & 31.96 & 1.17 & $-0.75^{* *}$ & 32.30 & 1.04 & 32.7 & 1.19 & $-0.40 *$ \\
\hline P-LM & 31.32 & 1.07 & 32.04 & 1.03 & $-0.72^{* *}$ & 32.32 & 0.98 & 32.79 & 1.14 & $-0.47^{*}$ \\
\hline P-KL & 31.30 & 1.12 & 32.04 & 1.03 & $-0.74^{* *}$ & 32.76 & 0.84 & 33.06 & 0.94 & -0.30 \\
\hline P-KM & 31.19 & 1.07 & 32.21 & 1.04 & $-1.02^{* *}$ & 32.68 & 0.91 & 33.42 & 0.82 & $-0.74 * *$ \\
\hline
\end{tabular}

Table 13 shows a summary of the values obtained within 3 areas per view.

The medial and lateral areas of every area have been joined to optimize the statistical analysis (thigh, knee, leg areas). We have found the highest differences between P1 and $\mathrm{P} 2$ on the thighs (anterior and posterior area) of the injured leg, $1.5^{\circ} \mathrm{C}$ and $1.47^{\circ} \mathrm{C}$, $t_{24}=-4.7(p<.001)$ and $t_{24}=-5.85(p<.001)$ respectively, and the thighs of the non-injured leg, anterior and posterior area, $1.63^{\circ} \mathrm{C}$ and $1.29^{\circ} \mathrm{C}, \mathrm{t}_{24}=-3.61(\mathrm{p}<.001)$ and $\mathrm{t}_{24}=-5.05$ $(p<.001)$ respectively. Besides these significant differences, the other results showed higher temperatures in all the areas in P2. All data we have obtained are statistically significant $(p<0.05)$ except the difference between P1 and P2 in the anterior view of the injured leg. 
Table 13.- Average temperature difference between P1 and P2 $\left({ }^{\circ} \mathrm{C}\right)\left({ }^{*} \mathrm{p}<.05{ }^{* *} \mathrm{p}<.01\right)$

\begin{tabular}{ccccc|ccc}
\hline & & \multicolumn{3}{c}{ ANTERIOR VIEW } & \multicolumn{3}{c}{ POSTERIOR VIEW } \\
& $\mathrm{P}$ & Thigh & Knee & Leg & Thigh & Knee & Leg \\
\hline \multirow{2}{*}{ INJURED LEG } & $\mathrm{P} 1$ & 29.20 & 30.07 & 31.42 & 30.18 & 30.95 & 30.93 \\
& $\mathrm{P} 2$ & 30.70 & 30.08 & 31.95 & 31.65 & 32.06 & 31.98 \\
& $\Delta \mathrm{T}_{\text {sk }} \mathrm{P} 1-\mathrm{P} 2$ & $-1.50^{* *}$ & -0.015 & $-0.53^{*}$ & $-1.47^{* *}$ & $-1.11^{* *}$ & $-1.05^{* *}$ \\
\hline \multirow{2}{*}{ NON-INJURED LEG } & $\mathrm{P} 1$ & 29.79 & 29.42 & 31.45 & 30.47 & 31.24 & 31.26 \\
& $\mathrm{P} 2$ & 31.42 & 30.15 & 32.00 & 31.76 & 32.12 & 32.00 \\
& $\Delta \mathrm{T}_{\text {sk }}$ P1-P2 & $-1.63^{* *}$ & $-0.73^{*}$ & $-0.55^{*}$ & $-1.29^{* *}$ & $-0.88^{* *}$ & $-0.735^{* *}$ \\
\hline
\end{tabular}

As the body behaves as a whole, we have analyzed data in only four areas: anterior injured, posterior injured, anterior non-injured, posterior non-injured. This procedure is due to the fact that temperature of a single area can affect the other's areas temperature distribution (Table 14 and Table 15).

Table 14.- General averaged skin temperature $\left(T_{\text {sk }}\right)$ differences for injured and noninjured leg between P1 and P2 $\left({ }^{\circ} \mathrm{C}\right) .\left({ }^{*} \mathrm{p}<.05 * * \mathrm{p}<.01\right)$

\begin{tabular}{cccc|cc}
\hline & & \multicolumn{2}{c}{ ANTERIOR VIEW } & \multicolumn{2}{c}{ POSTERIOR VIEW } \\
& & $\mathrm{X}$ & $\mathrm{SD}$ & $\mathrm{X}$ & $\mathrm{SD}$ \\
\hline \multirow{2}{*}{ INJURED LEG } & $\mathrm{P} 1$ & 30.4 & 0.84 & 31.09 & 0.82 \\
& $\mathrm{P} 2$ & 30.92 & 1.18 & 31.9 & 1.1 \\
& $\Delta \mathrm{T}_{\mathrm{sk}} \mathrm{P} 1-\mathrm{P} 2$ & -0.52 & & $-0.81^{* *}$ & \\
NON-INJURED & $\mathrm{P} 1$ & 30.56 & 1.01 & 31.45 & 0.79 \\
LEG & $\mathrm{P} 2$ & 31.03 & 1.23 & 31.96 & 1.08 \\
& $\Delta \mathrm{T}_{\text {sk }}$ P1-P2 & -0.47 & -0.22 & $-0.51^{*}$ & \\
\hline
\end{tabular}


Table 15.- Maximum skin temperature $\left(\mathrm{T}_{\mathrm{sk}}\right)$ differences between $\mathrm{P} 1$ and $\mathrm{P} 2\left({ }^{\circ} \mathrm{C}\right)$. $(* p<.05 * * p<.01)$

\begin{tabular}{cccc|cc}
\hline & & \multicolumn{2}{c}{ ANTERIOR VIEW } & \multicolumn{2}{c}{ POSTERIOR VIEW } \\
& & $\mathrm{X}$ & $\mathrm{SD}$ & $\mathrm{X}$ & $\mathrm{SD}$ \\
\hline \multirow{2}{*}{ INJURED LEG } & $\mathrm{P} 1$ & 31.95 & 0.76 & 32.31 & 0.78 \\
& $\mathrm{P} 2$ & 32.2 & 1.09 & 32.9 & 0.99 \\
& $\Delta \mathrm{T}_{\text {sk }}$ P1-P2 & -0.25 & & $-0.59^{*}$ & \\
NON-INJURED & $\mathrm{P} 1$ & 31.69 & & 32.7 & 0.65 \\
LEG & $\mathrm{P} 2$ & 32.27 & 1.12 & 32.91 & 0.98 \\
& $\Delta \mathrm{T}_{\text {sk }}$ P1-P2 & $-0.58^{*}$ & & -0.21 & \\
\hline
\end{tabular}

The Student $t$-test for related samples showed that there were significant changes in global average temperatures between P1 and P2 in the posterior view of the injured leg,$t_{24}=-3.18(p=0.004)$, and non-injured leg, $t_{24}=-2.09(p=0.047)$ (Table 14).

The Student $t$-test for related samples showed that there were significant differences in maximum temperatures (Table 15) in the posterior area of the injured leg between P1 and P2; $t_{24}=-2.61(p=0.015)$. In the anterior view of the non-injured leg, significant differences also were found; $t_{24}=-2.75 ;(p=0.04)$.

\subsection{STUDY IV}

Figure 13 represents the values from table 16 and compares data between the injured and non-injured leg between P1 (values a week after rehabilitation) and P2 (values 18 months after rehabilitation). 


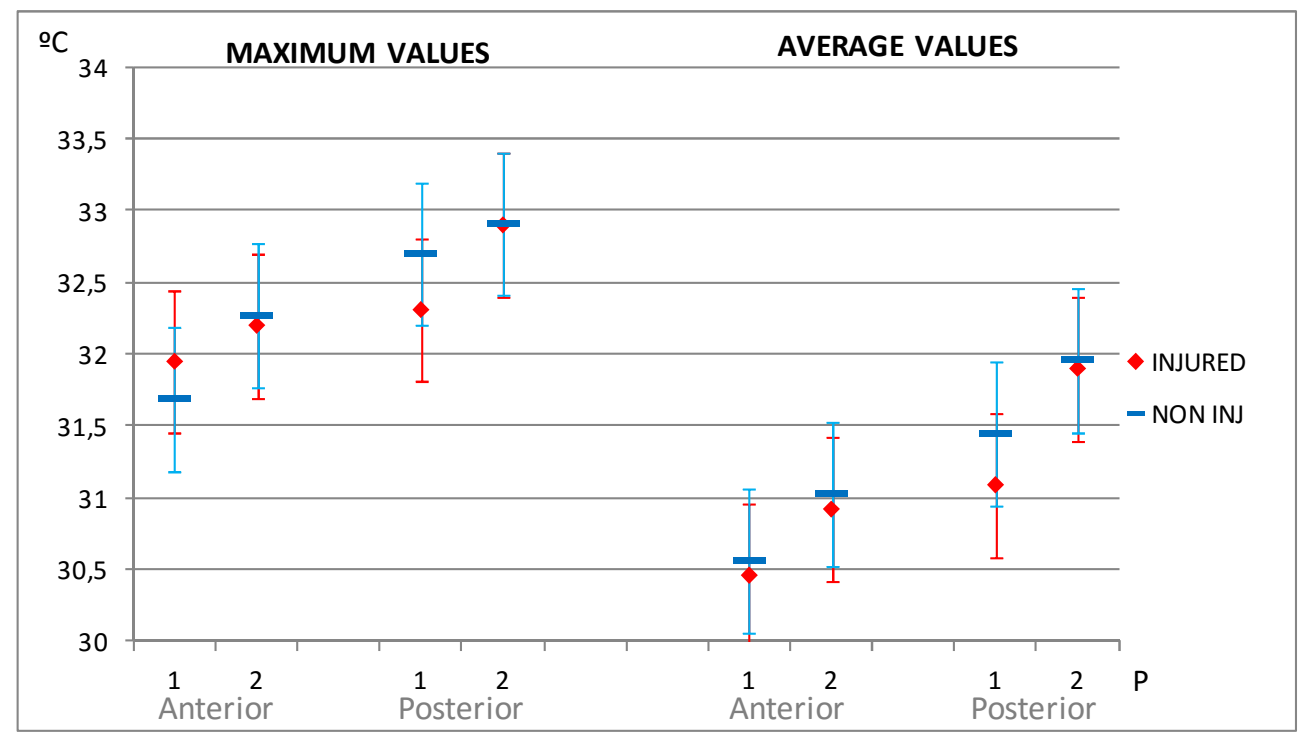

Figure 13.- Maximum and mean values of temperature of the injured and non-injured legs in P1 and P2.

According to the figure 13 and the table 16 we can observe that in P2 (stripes), temperatures of both legs are very close to each other (maximum and mean values). By contrast, in P1 the reverse is presented. The figure also shows that thermal values in P2 have increased when compared to P1. Moreover, all significant differences which were seen in P1 have disappeared in P2 (Table 16).

Table 16.- Mean values of the maximum and average temperatures of the anterior and posterior views in both periods (P) of the injured and non-injured leg (NON-INJ). $*(p<0.01) * *(p<0.05)$

\begin{tabular}{|c|c|c|c|c|c|c|c|c|c|}
\hline & & \multirow[t]{2}{*}{$P$} & \multicolumn{2}{|c|}{ INJURED $\left({ }^{\circ} \mathrm{C}\right)$} & \multicolumn{2}{|c|}{ NON-INJ $\left({ }^{\circ} \mathrm{C}\right)$} & \multirow[t]{2}{*}{$\Delta \mathrm{T}_{\mathrm{sk}}\left({ }^{\circ} \mathrm{C}\right)$} & \multirow[t]{2}{*}{$t_{24}$} & \multirow[t]{2}{*}{$p$} \\
\hline & & & $x$ & SD & $x$ & SD & & & \\
\hline \multirow{4}{*}{ MAXIMUM } & \multirow{2}{*}{ ANTERIOR } & 1 & 31.95 & 0.75 & 31.69 & 0.80 & $0.26^{* *}$ & 2.558 & 0.017 \\
\hline & & 2 & 32.20 & 1.09 & 32.27 & 1.12 & -0.07 & 0.726 & 0.475 \\
\hline & \multirow{2}{*}{ POSTERIOR } & 1 & 32.31 & 0.78 & 32.70 & 0.65 & $-0.39 *$ & 0.000 & -5.738 \\
\hline & & 2 & 32.90 & 0.98 & 32.91 & 0.98 & -0.01 & 0.906 & -0.120 \\
\hline \multirow{4}{*}{ AVERAGE } & \multirow{2}{*}{ ANTERIOR } & 1 & 30.46 & 0.84 & 30.56 & 1.01 & -0.10 & 0.386 & -0.882 \\
\hline & & 2 & 30.92 & 1.18 & 31.03 & 1.23 & -0.11 & 0.286 & -1.092 \\
\hline & \multirow{2}{*}{ POSTERIOR } & 1 & 31.09 & 0.82 & 31.45 & 0.79 & $-0.36 *$ & 0.000 & -7.268 \\
\hline & & 2 & 31.9 & 1.11 & 31.96 & 1.08 & -0.06 & 0.205 & -1.302 \\
\hline
\end{tabular}


5. DISCUSSION 


\section{DISCUSSION}

Many studies that have used thermography as a tool to track athletes and injuries since this technology came into existence (Priego et al., 2015; Klute et al., 2014; Badza et al., 2012; Akimov et al., 2009; Bagarone, 1987; BenEliyahu, 1990, 1992; Bertmaring, 2008; Čoh \& Širok, 2007; Ferreira et al., 2008; Garagiola \& Giani, 1990, 1991; Gómez Carmona et al., 2008; Gross et al., 1989; Hildebrandt \& Raschner, 2009; Hildebrandt et al., 2010; Katz et al., 2008; Keyl \& Lenhart, 1975; Mangine et al., 1987; Pochaczevsky, 1987; Rochcongar \& Schmitt, 1979; Roehl et al., 2009; Sillero Quintana, et al., 2010; Tkacova, 2010; Vainer, 2000) have defended its use in sports and health. Our work also follows this line with the objective of establishing thermography as a tool that informs us about the objective condition of the subject and more particularly of the injury. The evolution of body surface temperature allows us to monitor the recovery status of the subjects and comparing the beginning status of the leg with the end status.

A healthy person with unknown pathology should not have a thermal difference between the contralateral legs of more than $0.27 \pm 0.2^{\circ} \mathrm{C}$ (Uematsu et al.,, 1988a, 1988b). To research this, Uematsu et al., performed a study of 90 healthy people. Patients were followed for 5 years. For further analysis, Uematsu et al., designed 40 regions on the subjects body surfaces to reach that conclusion.

\subsection{STUDY I}

\subsubsection{ANALYSIS OF TEMPERATURE}

According to the maximum data from Table 5, the biggest difference corresponds to the anterior thigh medial $(\mathrm{A}-\mathrm{TM})$ with $0.55^{\circ} \mathrm{C}$. However, the posterior 
view shows that in some areas (P-LL and P-LM) the temperature between P0 and P1 has increased over $0.2^{\circ} \mathrm{C}$.

In Table 6, it can be seen that most differences in temperature between the $\mathrm{P} 0$ and P1 relate to a higher temperature of the non-injured leg in P0. In the average data a maximum difference of $0.44^{\circ} \mathrm{C}$ can be noticed between the same side areas of the anterior thigh medial (A-TM). We can recognize a decrease in temperature from P0 to $\mathrm{P} 1$ in other anterior areas as thigh lateral $(\mathrm{A}-\mathrm{TL})$. In the posterior view, the biggest decrease occurred between the thigh lateral and medial areas (P-TM, P-TL). There are two areas in which the temperature was higher on $\mathrm{P} 1$ than on $\mathrm{P} 0$, but the differences were less than $0.1^{\circ} \mathrm{C}$. In the maximum data, the biggest difference corresponds also to the anterior thigh lateral $(\mathrm{A}-\mathrm{TL})$ with $0.46^{\circ} \mathrm{C}$, while the thigh medial difference decreased by $0.08^{\circ} \mathrm{C}$. However, the posterior view showed that both in the knee and leg areas the temperatures $\mathrm{P} 1$ were higher than on P0.

5.1.2. THERMOGRAPHIC PROFILE OF AN ACL INJURY BEFORE AND AFTER THE REHABILITATION PROGRAM

In Table 7 we have joined the medial and lateral results of each area, thus obtaining six areas per leg and three for each view (Lee \& Cohen, 2008). In Table 8, a simplified view in just one area is presented. Data show the greatest difference in the thigh in both anterior and posterior view in Table 7. In both cases the temperature of the last image is lower than the temperature of the first image. Table 8 also showed a higher temperature on P0 than on P1. This data indicates that indeed, the temperature is falling, probably due to the drop of the blood flow produced by an improvement in the injury state (Garagiola \& Giani, 1990; Mangine et al., 1987). 
Data in Table 8 showed significant differences in maximum values between the initial and the final state of temperature in the posterior areas of both legs. The temperature increased during the recovery process. Barker, Hughes and Babski-Reeves (2006) used thermal imaging to detect thermal changes after physical activity. They took pictures at different times of the activity to compare their evolution. They concluded that thermography was sensitive to thermal changes during the physical tasks, so it can detect the blood flow demand that produces the thermal changes and responses. Hunold et al., (1992) came to the same conclusion after a study where pictures were taken before, during and after ten-minute ergometer exercise. They could register temperature changes over $3^{\circ} \mathrm{C}$.

\subsubsection{GENERAL APRECIATIONS FROM STUDY 1}

Our results showed that there was a different thermal behavior of the anterior and posterior view of legs as explained before. We believe it was due to the offset and muscle compensation which occurs during or prior the recovery period because subjects could try to protect the injured leg. We noticed that while walking they loaded more their healthy legs. This extra work could be the reason why the noninjured leg was also affected with an increase of temperature in the posterior area prior and during the rehabilitation process.

\subsection{STUDY II}

According to Garagiola and Giani (1990), a sharp peak in temperature occurs after an injury. In this study there were actually two injuries, the ACL rupture and the $\mathrm{ACL}$ reconstruction, which is widely invasive because the knee ligament must be replaced (Ventura, 2010). 
The results of maximum temperatures on PO showed that there was hyperthermia in the injured leg compared to the non-injured one, but only in the anterior view. This means that the front of the injured leg P0 had higher $T_{\text {sk }}$ peaks than the non-injured leg. This result contrasted strongly with data from the posterior area of the leg, which was completely the opposite. On P0, the temperature of the posterior view of the non-injured leg was significantly warmer.

The results of the average temperature on P0 did not show large differences between the anterior views of both legs but they did in the posterior views. As with the maximum data, the average temperature was significantly higher in the posterior view of the non-injured leg than in the injured leg. We can observe this phenomenom in Figure 12.

The justification for this phenomenom can be found in the work of Piñonosa et al. (2013) and Bagarone (1987) which explains how a healthy body structure may deteriorate if its symmetrical structure, in this case the leg, is injured. This injury caused an overuse of the healthy leg, which is not used to this extra effort and develops an imbalance in the muscles, so that it needed more nutrients and blood flow to maintain the activity. At this point, subjects also limped. This prolonged lameness may cause an overload of the other leg and especially in the posterior area as can be seen in the results. This workload may be the reason why posterior areas showed higher temperatures. Colné and Thoumie (2006) suggested that a bilateral increase in soleus activity was related to an increment of the duration in the balance recovery process in all patients of $A C L$ reconstruction. Patients used one or two strategies to recover balance regardless of the treatment: reducing the step length, involving an early recruitment of the soleus before heel contact, or anticipating braking with a 
similar step length requiring a predominant activity of the hamstrings. These results from Colné and Thoumie suggested that bilateral activity of the soleus was involved to compensate for instability and highlight the contribution of the soleus to rehabilitation after an anterior cruciate ligament injury, not only as a compensatory muscle acting at the knee level but also at a higher level in the bilateral control of stance.

At this point, professionals of the rehabilitation should be aware about this behavior and monitor the recovery of both legs, not only the injured one.

In $\mathrm{P} 1, \Delta \mathrm{T}_{\text {sk }}$ between both legs remained, although the temperature difference between the injured and non-injured leg or vice-versa had indeed fallen. Thus, results still showed significant $T_{\text {sk }}$ differences at the end of rehabilitation, but these differences had decresead from the beginning of rehabilitation (Tables 9 and 10). However, the only data that had remained constant in both stages were the difference between the averages of the posterior area. This suggests that the subjects, from a thermal point of view, had not evolved. It is likely that they were limping during the rehabilitation and therefore, overloading this area and maintaining the posterior leg $T_{\text {sk }}$ (Piñonosa, et al., 2013). But we can guess that in a point of the rehabilitation, the lameness might have decreased, because if the subject had limped during the whole rehabilitation until the final week, the temperature of the posterior view of the noninjured leg should have increased also, and that was not the case, since it stayed constant. Then, we might venture that the $T_{s k}$ of the posterior area was tending to decrease in P1, and probably if we had followed the subjects after their rehabilitation, temperatures of both the posterior and anterior views would have approached symmetrical values as we will discuss in Studies 3 and 4 . With this study we have demonstrated that we should always keep in mind the two symmetrical parts of the 
body, and especially the legs, as they support the body weight. When an injured leg becomes non-functional, its load is considerably reduced, and the responsibility of the leg that is in good condition increase and is forced to endure much more weight than it is used to, as we can appreciate in the results. The thermographic camera was able to assess where the workload was affecting the most.

Based on these results and adding our experience in the San Carlos Clinical Hospital and our conversations with rehabilitation physicians and physiotherapists, this occurs in almost all cases when patients recover from a knee injury but patients usually acquire a wrong motor walking habit, which produces overload in the healthy leg. Thus, reassessment by the physical therapist during rehabilitation must be ongoing and comprehensive in effort to identify all sources of impairment as soon as they begin to develop. At which time immediate treatment modifications addressing all areas of impairment must be implemented to ensure the best possible outcome and prevent the need for additional surgical intervention (Potter, 2006). As it has been demonstrated throughout the text, thermography can easily assess these impairments.

\subsection{STUDY III}

\subsubsection{ANALYSIS OF TEMPERATURE}

Our study tries to discover if the temperature has boosted, plummeted or remained steady between two time points (P1 and P2). Therefore, we have compared the initial and final state of both legs (injured and non-injured leg). This comparison completes the study of Piñonosa et al. (2013), where the time points recorded were before and after rehabilitation. In the average data of Table 11 (injured leg), we observed significant higher temperatures in P2 than in P1. It is surprising that only three areas did not suffered significant changes, and both areas of the knee among 
them. Furthermore, the temperature of one of the knee areas has decreased between P1 and P2, though the injury was located there originally. Besides this evidence, we have found in maximum values this same behavior, but this time, with significant values in one knee area (A-KM).

In agreement with the results of recent studies conducted by Romano (2012), the temperature of the injured leg has evolved significantly from the reconstruction. In $\mathrm{P} 2$, the temperature of the knee was lower than the surrounded areas.

In Table 12 (non-injured leg) we have detected a significant temperature increment in every area. As Garagiola and Giani (1990) describe, after a long recovery period, subjects are used to limp, even when they are supposed to be completely recovered. Probably they walk this way subconsciously. This behavior could be the point of this increment.

\subsubsection{THERMOGRAPHIC PROFILE OF AN ACL INJURY AFTER A REHABILITATION} PROGRAM AND 18 MONTHS LATER

In Table 13, similar findings than Table 11 were seen. Data showed the greatest difference in the anterior view of the thigh, which can be caused by an overload or by a heat redistribution toward the proximal parts of the body. In contrast, the lowest difference in the anterior view of the injured leg was located in the knee.

In Table 14, as it happened in all areas (anterior and posterior), temperature in $\mathrm{P} 2$ is higher than temperature in P1. These results remark the most important differences within the posterior views, either in the injured leg $(p<0.01)$ or in the noninjured leg $(p<0.05)$.

Concerning to maximum values, table 15 showed significant differences in the anterior view of the non-injured leg, presumably as a result of overloading the non- 
injured leg. Though, in the posterior view of the injured leg the temperature has also boosted, likely because of the subjects did not extend the knee properly and they are overloading the posterior muscles and underloading the anterior ones.

\subsubsection{GENERAL APRECIATIONS FROM STUDY 3}

Our results showed that temperature has enhanced since the subjects had finished the recovery. However, beyond a short period of time after the reconstruction, the temperature of the injured area (knee) still stays up (Piñonosa, 2013). It seems that after a long period of time the temperature of the injured knee remained stable in the anterior view. Nevertheless, the temperature of all the areas around have raised up. Perhaps this is due to a temperature redistribution of the injured leg. The non-injured leg also showed a higher temperature in P2 when compared to P1. The reason could be the subconscious lameness that often this kind of injury presents. This is the claim that patients usually used one of these strategies to recover balance: reducing the step length, involving an early recruitment of the soleus before heel contact, or anticipating braking with a similar step length requiring a predominant activity of the hamstrings (Colné \& Thoumie, 2006).

With this study we can determine that thermography can be a good tracking tool when a quick and objective monitoring of the structures damaged by an injury is required, especially long-term rehabilitations. Following similar works, this study reveals that the baseline temperature of injured and non-injured leg are different even after a long period (Litscher, 2013). This tool allows us to check the skin surface heat emission, which can be very useful as many metabolism changes detach temperature variations, easily captured by a thermographic camera. One goal of this study was to 
describe temperature distribution and the effects on surface temperature of the knees in subjects with an anterior cruciate ligament reconstruction.

During this study, we discovered a thermal balance between the anterior and posterior view in both knees and in both Periods (P1 and P2). We have noticed that the temperature of the posterior view is always higher than the temperature of the anterior view. This phenomenon can be checked at Table 13. While the mean difference in $\mathrm{P} 1$ is $1.35^{\circ} \mathrm{C}$, in $\mathrm{P} 2$ the mean difference has boosted until $1.97^{\circ} \mathrm{C}$. As a result, this research line is suggested for future studies.

\subsection{STUDY IV}

Thermal values of symmetrical parts of the body surface should be similar (Ammer, 2008; Vardasca, 2008) with a small range of variation. After a long period of time (18 months), it stands to reason that both legs had reached similar temperature values and thus, the thermal differences had disappeared. Haidar et al (2006) conducted a similar study whose goal was to establish the pattern of knee skin temperature following uncomplicated primary total knee replacement. Their measurements were taken at 3, 6, 12 and 24 months following surgery. They found that firstly, the operated knee $T_{s k}$ increased comparing to the contralateral knee. However, the difference decreases steadily, but remains statistically significant up to at least 6 months after surgery. Between 12 and 24 months the impairment had disappeared. Piñonosa et al (2013) tracked the thermal evolution of both legs throughout the rehabilitation of an $\mathrm{ACL}$ reconstruction and concluded that the temperature of the posterior view of both legs had boosted at the end of the rehabilitation ( 6 week) instead of decreasing. These results suggested that a further monitoring over the time was needed. 
As seen on figure 13 , we can highlight that the values of P2 seem to be very similar in both legs average and maximum data. This means that the temperature of both legs had approached each other during the last year and a half. Actually, the highest $\Delta \mathrm{T}_{\text {sk }}$ in $\mathrm{P} 2$ is $0.11^{\circ} \mathrm{C}$, which is far from the values that others authors marked as important imbalance: Vardasca (2008), $0.27^{\circ} \mathrm{C}$; BenEliyahu (1990), $0.29^{\circ} \mathrm{C}$; Hildebrandt et al. (2010), 0,62 ${ }^{\circ} \mathrm{C}$; Niu et al. (2001); and Uematsu et al., (1985), $0.5^{\circ} \mathrm{C}$ ). 
6. CONCLUSIONS 


\section{CONCLUSIONS}

\subsection{CONCLUSION OF THE MAIN OBJECTIVE}

With these studies we can say that thermography can be a good tool when a rapid and objective monitoring of the damaged structures by an injury is required. Thermography has shown the ability of collecting reliable data in a shorter period of time, this facilitates the use of thermography in professional activities although a long acclimatization time (as other tools require) may be a limiting factor for the use of thermography in athletes, factory workers and hospitalized patients.

\subsection{STUDY I}

a) This study demonstrates that there was a temperature increase in the posterior area of the injured leg between P0 and the P1.

b) This study demonstrates that there was a temperature increase in the posterior area of the non-injured leg between $\mathrm{P} 0$ and $\mathrm{P} 1$.

c) Significant differences were not found in any other measures, so we can conclude that the temperatures of other areas were similar on $\mathrm{P} 0$ and $\mathrm{P} 1$, meaning the body structures had not fully recovered during the rehabilitation period.

\subsection{STUDY II}

a) Temperatures of both legs (injured and non-injured) are assymmetrical before the rehabilitation process.

b) Temperaturess of both legs (injured and non-injured) are still assymmetrical after the rehabilitation process, especially in the posterior view, where the $T_{\text {sk }}$ of the non-injured leg is significantly higher. 
6.4. STUDY III

a) \& b) The temperature of lower limbs 18 months after having concluded the recovery period is higher than just after rehabilitation.

\subsection{STUDY IV}

a) We can conclude that 18 months after the rehabilitation, participants seem to have standardized their thermal values in both legs. We did not found temperature difference between the injured leg and non-injured leg. 18 months after the end of rehabilitation. This fact means that 18 months after the end of rehabilitation the $T_{\text {sk }}$ of both legs is symmetrical. 
7. LIMITATIONS OF THE WORK 


\section{LIMITATIONS OF THE WORK}

After the experience gained during the development of data collection, the difficulties involved in it, and discussion of the results, we have a critical view of the work focused on the next points:

- The sample can always be greater, so it could provide more meaningful and universal results. In this study there has been little female participation, although this same matter in $\mathrm{ACL}$ injury rates in both production mechanism.

- It is very difficult to control everything made by the subjects out of rehabilitation, especially during the 18 months after the rehabilitations.

- The difficult to control the medicine intake during all the process.

- Regarding the analysis of data, the data collection process is fast, however, the process of analyzing the thermograms to extract the temperature data of images is slow (10 to 15 minutes per picture) and with some margin of error. By creating areas and adapt to each photo of each subject it is possible that a slight deviation occurs in one of them that does not exactly match the rest. A tool to help extract information from the thermal image with validity, reliability and speed would be required.

- IRT has limitations linked to the factors, which are hardly manageable. According to Konen (2000), problems related to equipment and standardization in IRT studies hinder its feasibility, and some of the existing IRT cameras for humans still could have a better accuracy. Some of these factors may be controlled by carrying out a standardized protocol (Fernández-Cuevas, et al., 2015). However, as it was shown in the review literature, there is a large list of factors, which have not been (enough) analysed yet, and whose influence on $T_{\text {sk }}$ 
is still somehow unpredictable (age, gender, subcutaneous fat, tobacco intake...).

- The ROIs are different among IRT studies. This makes hard to compare data.

- The templates used in IRT depend only on the researcher, as there is no a protocol to standardized the ROIs. 
8. FUTURE RESEARCH LINES 


\section{FUTURE RESEARCH LINES}

There is still a huge amount of work to be done. During the development of this work new ideas and lines of research has been considered for further investigations:

- To compare the $T_{s k}$ evolution of this rehabilitation program of the $A C L$ with some others rehabilitation programs.

- Regarding the ACL rupture would be very interesting to track from the start of the injury, and follow it until full recovery, even years afterwards.

- After the experience of this research, I believe very useful the possibility of making a comparative study of the evolution of the subjects correlating the waiting time from the surgery to the start of rehabilitation.

- The range of this tool is immense and unexplored. It could be done the same with any injury and establish the thermal profiles of each. Thus it could show whether the diagnosis of an injury by thermal map image is possible.

- To use IRT as a following method at the treatment of other typical sport injuries.

- To study deeply all kind of factors that can influence in the $T_{\text {sk }}$ evaluation.

- To improve the IRT software in order to eliminate the residual errors and reach perfect reliability values, and make a new system and features as 3D or virtual analysis.

- We believe that thermography could be used to quantify the effects and assimilation of the training workloads. Further investigations should describe the effects of different training methods at different volume and intensities of work and compare the results with other tools. IRT can be used too to evaluate recovery processes. 
- IRT as a prevention tool is a potential application as many authors have evaluated (E. Akimov \& Son'kin, 2011; Chudecka \& Lubkowska, 2010; Merla, et al., 2010; Sillero Quintana, et al., 2010) 
9. REFERENCES 
82 


\section{REFERENCES}

Abate, M., Di Carlo, L., Di Donato, L., Romani, G. L., \& Merla, A. (2013). Comparison of cutaneous termic response to a standardised warm up in trained and untrained individuals. J Sports Med Phys Fitness, 53(2), 209-215.

Acharya, U. R., Ng, E. Y., Tan, J. H., \& Sree, S. V. (2010). Thermography Based Breast Cancer Detection Using Texture Features and Support Vector Machine. Journal of Medical Systems, 1, 8-12.

Akimov, E., \& Son'kin, V. (2011). Skin temperature and lactate threshold during muscle work in athletes. Human Physiology, 37(5), 621-628.

Akimov, E. B., Andreev, R. S., Arkov, V. V., Kirdin, A. A., Saryanc, V. V., Sonkin, V. D., et al. (2009). Thermal "portrait" of sportsmen with different aerobic capacity. Acta Kinesiologiae Universitatis Tartuensis, 14, 7-16.

Alcaraz, C. A. (2007). Acl Tear Football Injury. Medicine and science in sports and exercise, 39(supplement), S128-S129.

Alvares, B. R., \& Michell, M. (2003). O uso da ressonância magnética na investigação do câncer mamário. Radiologia Brasileira, 36, 373-378.

Ammer, K. (2008). The Glamorgan Protocol for recording and evaluation of thermal images of the human body Thermology International, 18(4), 125-129.

Ammer, K., \& Ring, E. F. (2005). Influence of the field of view on temperature readings from thermal images. Thermology International, 15(3), 99-103.

Ammer, K., \& Ring, E. F. J. (2007). Standard procedures for Infrared Imaging in Medicine. In N. A. Diakides \& J. D. Bronzino (Eds.), Medical Infrared Imaging (pp. 22-21 to 22-14). United States: Taylor \& Francis.

Autio, E., Neste, R., Airaksinen, S., \& Heiskanen, M. L. (2006). Measuring the heat loss in horses in different seasons by infrared thermography. J Appl Anim Welf Sci, 9(3), 211-221.

Avdelidis, N. P., \& Moropoulou, A. (2004). Applications of infrared thermography for the investigation of historic structures. Journal of Cultural Heritage, 5(1), 119-127.

Badza, V., Jovancević, V., Fratrić. F., Roglić, G., Sudarov, N. Possibilities of thermovision application in sport and sport rehabilitation. Vojnosanit Pregl, 69(10):904-7.

Bagarone, A. (1987). Correlation between clinical and telethermographic evaluation in overuse injuries treatment. Journal of sports medicine and physical fitness, 27(1), 64-69.

Balageas, D. L. (2007). Termografía infrarroja: una técnica multifacética para la Evaluación No Destructiva (END). Paper presented at the IV Conferencia Panamericana de Ensayos No Destructivos END, Buenos Aires.

Barker, L. M., Hughes, L. E., \& Babski-Reeves, K. L. (2006). Efficacy of Using Thermography to Assess Shoulder Loads During Overhead Intermittent Work. Paper presented at the Human Factors and Ergonomics Society Annual Meeting Proceedings.

Barnes, R. B. (1963). Thermography of the Human Body. Science, 140(3569), 870-877.

BenEliyahu. (1990). Infrared thermography in the diagnosis and management of sports injuries: a clinical study and literature review. Chiropractic Sports Medicine. , 4(2), 4653.

BenEliyahu, D. (1992a). Infrared thermography and the sports injury practice. Dynamic Chiropractic, 10(7).

BenEliyahu, D. J. (1992b). Infrared thermographic imaging in the detection of sympathetic dysfunction in patients with patellofemoral pain syndrome. J Manipulative Physiol Ther, 15(3), 164-170.

Benetos, G., Toutouzas, K., Drakopoulou, M., Tolis, E., Masoura, C., Nikolaou, C., Tsekoura, D., Tsiamis, E., Grassos, H., iores, E., Stefanadis, C., Tousoulis, D. (2015). Bilateral symmetry of local inflammatory activation in human carotid atherosclerotic plaques. Hellenic J Cardiol, 56(2):118-24. 
Bertmaring, I. (2008). Infrared imaging of the anterior deltoid during overhead static exertions. Ergonomics, 51(10), 1606.

Bianchi, S. D., G Gatti, G., \& Mecozzi, B. (1979). Circadian variations in the cutaneous thermal map in normal subjects. Acta Thermographica, 4(3), 95-98.

Binder, A., Parr, G., Thomas, P. P., \& Hazleman, B. (1983). A clinical and thermographic study of lateral epicondylitis. BrJ Rheumatol, 22(2), 77-81.

Birch, J., Branemark, P. I., \& Nilsson, K. (1969). The vascularization of a free full thickness skin graft. 3. An infrared thermographic study. Scandinavian journal of plastic and reconstructive surgery, 3(1), 18-22.

Bouzas, J. C., Fernandes, A. A., Piñonosa-Cano, S., Moreira, D. G., da Silva, F. S., Costa, C. M. A., et al. (2014). Thermal body patterns for healthy Brazilian adults (male and female). Journal of Thermal Biology, 42, 1-8.

Bouzas Marins, J. C., Gomes Moreira, D., Piñonosa Cano, S., Sillero-Quintana, M., Dias Soares, D., de Andrade Fernandes, A., et al. (2014). Time required to stabilize thermographic images at rest. Infrared Physics \& Technology, 65(0), 30-35.

Brelsford, K. L., \& Uematsu et al.,, S. (1985). Thermographic presentation of cutaneous sensory and vasomotor activity in the injured peripheral nerve. J Neurosurg, 62(5), 711-715.

Brioschi. (2006). A história da Termografia. Retrieved 9-1-2016, from http://www.lla.if.sc.usp.br/art/ahistoriadatermografia.pdf

Brioschi, M. L., Macedo, J. F., \& Coelho, R. (2003). Termometria cutânea: novos conceitos. J Vasc $B r, 2(2), 151-160$.

Brodersen, J., Jorgensen, K. J., \& Gotzsche, P. C. (2010). The benefits and harms of screening for cancer with a focus on breast screening. Pol Arch Med Wewn, 120(3), 89-94.

Brusselmans, G., Nogueira, H., De Schamphelaere, E., Devulder, .J, Crombez, G.(2012) Skin Temperature during Cold Pressor Test in Fibromyalgia: an Evaluation of the Autonomic Nervous System? Acta Anaesthesiol Belg, 66(1):19-27.

Caine, D. J., Cochrane, B., Caine, C., \& Zemper, E. (1989). An epidemiological investigation of injuries affecting young competitive female gymnasts. American Journal of Sports Medecine, 17, 811-820.

Ciutacu, O., Tanase, A., \& Miclaus, I. (2006). Digital infrared thermography in assessing soft tissues injuries on sport equines. Bulletin of the University of Agricultural Sciences and Veterinary Medicine, Vol 63, 2006, 63, 228-233.

Clark, R. P., Mullan, B. J., \& Pugh, L. G. (1977). Skin temperature during running -a study using infra-red colour thermography. J Physiol, 267(1), 53-62.

Čoh, M., \& Širok, B. (2007). Use of the thermovision method in sport trainning. Physical Education and Sport., 5(1), 85-94.

Colné, P., \& Thoumie, P. (2006). Muscular compensation and lesion of the anterior cruciate ligament: Contribution of the soleus muscle during recovery from a forward fall. Clinical Biomechanics, 21(8), 849-859.

Costa, F., Piñonosa, S., Gómez, P., Sillero, M., \& Merussi, C. (2012). Infrared thermography to quantify the risk of breast cancer. Bioimages, 20, 1-7.

Chamberlain, J. M., Terndrup, T. E., Alexander, D. T., Silverstone, F. A., Wolf-Klein, G., O'Donnell, R., et al. (1995). Determination of Normal Ear Temperature with an Infrared Emission Detection Thermometer. Annals of Emergency Medicine, 25(1), 15-20.

Chen, Z., Jiang, G., Zheng, F., Liu, H., \& Zhu, B. (2005). A Correction method of medical thermography's distortion. Conf Proc IEEE Eng Med Biol Soc, 2, 1677-1679.

Chiang, M. F., Lin, P. W., Lin, L. F., Chiou, H. Y., Chien, C. W., Chu, S. F., et al. (2008). Mass screening of suspected febrile patients with remote-sensing infrared thermography: alarm temperature and optimal distance. J Formos Med Assoc, 107(12), 937-944.

Choi, J. K., Miki, K., Sagawa, S., \& Shiraki, K. (1997). Evaluation of mean skin temperature formulas by infrared thermography. Int J Biometeorol, 41(2), 68-75. 
Chudecka, M., \& Lubkowska, A. (2010). Temperature changes of selected body's surfaces of handball players in the course of training estimated by thermovision, and the study of the impact of physiological and morphological factors on the skin temperature. Journal of Thermal Biology, 35(8), 379-385.

Day, R. (2005). Condition monitoring utilising infrared thermography in a power generation environment. Insight, 47(9), 547-550.

De Carlo, M. (2010). Rehabilitation of the Knee Following Sports Injury. Clinics in Sports Medicine, 29(1), 81.

Di Carlo, A. (1995). Thermography ant the possibilities for its applications in Clinical and experimental dermatology. Clinics in Dermatology(15), 329-336.

Dittmar, A., Gehin, C., Delhomme, G., Boivin, D., Dumont, G., \& Mott, C. (2006). A non invasive wearable sensor for the measurement of brain temperature. Engineering in Medicine and Biology Society, 1, 900-902.

Donna, L., \& Harper, D. V. M. (2005). The value of infrared Thermography in the diagnosis and prognosisi of injuries in animals. Retrieved from www.goinfrared.com/media/016harper.pdf

Engström, B., Forssblad, M., Johansson, C., \& Tornkvist, H. (1990). Does a major knee injury definitely sideline an elite soccer player? Am J Sports Med, 18(1), 101-105.

Feng, T., Zhao, P., \& Liang, G. (1998). Diagnostic significance of topical image of infrared thermograph on the patient with lumbar intervertebral disc herniation--a comparative study on 45 patients and 65 normal control. Zhongguo Zhong Xi Yi Jie He Za Zhi, 18(9), 527-530.

Fernández-Cuevas, I., Bouzas Marins, J. C., Arnáiz Lastras, J., Gómez Carmona, P. M., Piñonosa Cano, S., García-Concepción, M. Á., et al. (2015). Classification of factors influencing the use of infrared thermography in humans: A review. Infrared Physics \& Technology, 71, 28-55.

Ferreira, J. J., Mendonca, L. C., Nunes, L. A., Andrade Filho, A. C., Rebelatto, J. R., \& Salvini, T. F. (2008b). Exercise-associated thermographic changes in young and elderly subjects. Annals of biomedical engineering, 36(8), 1420-1427.

Formenti, D., Ludwig, N., Gargano, M., Gondola, M., Dellerma, N., Caumo, A., et al. (2013). Thermal Imaging of Exercise-Associated Skin Temperature Changes in Trained and Untrained Female Subjects. Annals of Biomedical Engineering, 41(4), 863-871.

Foster, K. R. (1998). Thermographic detection of breast cancer. Engineering in Medicine and Biology Magazine, IEEE, 17(6), 10-14.

Fournet, D., Ross, L., Voelcker, T., Redortier, B., \& Havenith, G. (2013). Body mapping of thermoregulatory and perceptual responses of males and females running in the cold. Journal of Thermal Biology, 38(6), 339-344.

Galindez, I. (2010). Aproximación al riesgo y confort térmico en el trabajo: El frío. Retrieved 15/08/2016, from http://www.ergokprevencion.org

Garagiola, \& Giani. (1990). Use of telethermography in the management of sports injuries. Sports Medicine., 10(4), 267-272.

Garagiola, \& Giani. (1991). Thermography: Description, Uses in Sports Medicine. Unpublished article by Encyclopedia of Sports Medicine and Science.

Geneve, R. (1971). Physical aspects of medical thermography and instrumentation. Revue Generale de Thermique, 10(111), 239-254.

George, J., Bensafi, A., Schmitt, A. M., Black, D., Dahan, S., Loche, F., et al. (2008). Validation of a non-contact technique for local skin temperature measurements. Skin Res Technol, 14(4), 381-384.

Gershon-Cohen, J., \& Haberman, J. D. (1968). Thermography of smoking. Archives of environmental health, 16(5), 637-641. 
Gómez Carmona, P. M., Sillero Quintana, M., Noya Salces, J., \& Pastrano León, R. (2008). Infrared Thermography as an injury prevention method in soccer. Paper presented at the XXX FIMS World Congress of Sports Medicine, Barcelona, Spain.

Goodman, P. H., Heaslet, M. W., Pagliano, J. W., \& Rubin, B. D. (1985). Stress fracture diagnosis by computer assited thermography. Physician and Sportsmedicine, 13(4), 114-118.

Grimnes, K. H. (2000, Apr 25-27). Thermography in Norway - History and state of the art. Paper presented at the Thermosense XXII Conference, Orlando, FI.

Gross, M. T., Schuch, C. P., Huber, E., Scoggins, J. F., \& Sullivan, S. H. (1989). Method for quantifying assessment of contact thermography: effect of extremity dominance on temperature distribution patterns. J Orthop Sports Phys Ther, 10(10), 412-417.

Haidar, S. G., Charity, R. M., Bassi, R. S., Nicolai, P., \& Singh, B. K. (2006). Knee skin temperature following uncomplicated total knee replacement. The Knee, 13(6), 422-426.

Hamilton, G. (1998). Investigations of the thermal properties of human and animal tissues.(Phd). University of Glasgow.

Harada, N., Iwamoto, M., Laskar, M. S., Hirosawa, I., Nakamoto, M., Shirono, S., et al. (1998). Effects of room temperature, seasonal condition and food intake on finger skin temperature during cold exposure test for diagnosing hand-arm vibration syndrome. Ind Health, 36(2), 166-170.

Hardy, J. D. \& Muschenheim. C. (1934) The Radation of Heat from the Human Body. Iv. The Emission, Reflection. and Transmission of Infra-Red Radiation by the Human Skin. J Clin Invest, 13(5), 817-831.

Hardy, J. D., \& Du Bois, E. F. (1940). Differences between men and women in their response to heat and cold. Proceedings of the National Academy of Sciences of the United States of America, 26, 389-398.

Havenith, G. (2001). Human surface to mass ratio and body core temperature in exercise heat stress--a concept revisited. Journal of Thermal Biology, 26(4-5), 387-393.

Helmy, A., Holdmann, M., \& Rizkalla, M. (2008). Application of thermography for non-invasive diagnosis of thyroid gland disease. IEEE Trans Biomed Eng, 55(3), 1168-1175.

Hildebrandt, \& Raschner. (2009). Medical infrared thermography as a screening tool for knee injuries in professional junior alpine-ski-racers in Austria - Findings of a pilot study. Paper presented at the 14th annual ECSS Congress.

Hildebrandt, Raschner, \& Ammer. (2010). An overview of recent application of medical infrared thermography in sports medicine in Austria. Sensors, 10(5), 4700-15.

Hlawatsch, A., Teifke, A., Schmidt, M., \& Thelen, M. (2002). Preoperative assessment of breast cancer: sonography versus MR imaging. AJR Am J Roentgenol, 179(6), 1493-1501.

Hunold, S., Mietzsch, E., \& Werner, J. (1992). Thermographic studies on patterns of skin temperature after exercise. European journal of applied physiology and occupational physiology, 65(6), 550-554.

IACT. (2002). Thermology Guidelines. Standards and protocolos in Clinical Thermography Imaging. 9. Retrieved from http://www.iact-org.org/professionals/thermogguidelines.html

Incropera, F. P. (1999). Fundamentos de transferencia de calor. Mexico: Prentice Hall.

Isard, H. J., Becker, W., Shilo, R., \& Ostrum, B. J. (1972). Breast thermography after four years and 10000 studies. The American journal of roentgenology, radium therapy, and nuclear medicine, 115(4), 811-821.

Ivanitsky, G. R., Khizhnyak, E. P., Deev, A. A., \& Khizhnyak, L. N. (2006). Thermal imaging in medicine: A comparative study of infrared systems operating in wavelength ranges of 3-5 and 8-12 microm as applied to diagnosis. Dokl Biochem Biophys, 407, 59-63.

Jemal, A., Bray, F., Center, M. M., Ferlay, J., Ward, E., \& Forman, D. (2011). Global cancer statistics. A Cancer Journal for Clinicians, 61(2), 69-90.

Johnson, J. M. (1992). Exercise and the cutaneous circulation. Exerc Sport Sci Rev, 20, 59-97. 
Jones, B. F. (1998). A reappraisal of the use of infrared thermal image analysis in medicine. IEEE Trans Med Imaging, 17(6), 1019-1027.

Jorgensen, K. J., Klahn, A., \& Gotzsche, P. C. (2007). Are benefits and harms in mammography screening given equal attention in scientific articles? A cross-sectional study. BMC Med, 5,12 .

Katz, L. M., Nauriyal, V., Nagaraj, S., Finch, A., Pearlstein, K., Szymanowski, A., et al. (2008). Infrared imaging of trauma patients for detection of acute compartment syndrome of the leg. Critical Care Medicine, 36(6), 1756-1761.

Kennedy, D. A., Lee, T., \& Seely, D. (2009). A Comparative Review of Thermography as a Breast Cancer Screening Technique. Integrative Cancer Therapies, 8(1), 9-16.

Kenny, G. P., Reardon, F. D., Zaleski, W., Reardon, M. L., Haman, F., \& Ducharme, M. B. (2003). Muscle temperature transients before, during, and after exercise measured using an intramuscular multisensor probe. [Research Support, Non-U.S. Gov't]. J Appl Physiol, 94(6), 2350-2357.

Keyl, W., \& Lenhart, P. (1975). Thermography in sport injuries and lesions of the locomotor system due to sport. Fortschr Medicine. , 23(93(3)), 124-126.

Klute, G., Huff, E., Ledoux, R. (2014). Does activity affect residual limb skin temperatures?. Clin Orthop Relat Res, 472(10):3062-7.

Koay, J. P. S. (2005). Quantitative analysis of infrared images for early breast cancer detection [microform]. (PhD). Carleton University.

Kulesza, O., Rzeczkowski, M., \& Kaczorowski, M. (2004). Thermography and its practical use in equine diagnostics and treatment. Medycyna Weterynaryjna, 60(11), 1143-1146.

LaBorde, T. C. (1989). Thermography in diagnosis of radiculopathies. Clin J Pain, 5(3), 249-253.

Lahiri, B. B., Bagavathiappan, S., Jayakumar, T., \& Philip, J. (2012). Medical applications of infrared thermography: A review. Infrared Physics \& Technology, 55(4), 221-235.

Lawson, R., (1957). Thermography: A new tool in investigations of breast lesions. Can Serv Med $J, 8(8), 517-24$.

Lee, M., \& Cohen, J. (2008). Rehabilitation Medicine and Thermography. Morrisville: Impress Publications.

Leisman. (1990). Neuropsychological systems deficits and the isomorphism of control. Int J Neurosci, 54(1-2), 35-40.

Litscher, G. (2013). Manual Khalifa therapy in patients with completely ruptured anterior cruciate ligament in the knee: First preliminary results from thermal imaging. North American journal of medical sciences, 5(8), 473-479.

Livingston, S. D., Nolan, R. W., Frim, J., Reed, L. D., \& Limmer, R. E. (1987). A thermographic study of the effect of body composition and ambient temperature on the accuracy of mean skin temperature calculations. Eur J Appl Physiol Occup Physiol, 56(1), 120-125.

Lopez, R., Cleary, M., Jones, L., \& Zuri, R. (2008). Thermoregulatory Influence of a Cooling Vest on Hyperthermic Athletes. Journal of Athletic Training., 43(1), 55-61.

Lyon, R. (2004). The development of condition monitoring tools for the power generation industry. Insight, 46(9), 516-519.

Mabuchi, K., Kanbara, O., Genno, H., Chinzei, T., Haeno, S., \& Kunimoto, M. (1997). Automatic control of optimum ambient thermal conditions using feedback of skin temperature. Biomedical thermology, 16(4), 6-13.

Mangine, R. E., Siqueland, K. A., \& Noyes, F. R. (1987). The use of thermography for the diagnosis and management of patellar tendinitis. The Journal of orthopaedic and sports physical therapy, 9(4), 132-140.

Marinetti, S., Muscio, A., Bison, P. G., \& Grinzato, E. (2000). Modeling of thermal nondestructive evaluation techniques for composite materials. Thermosense Xxii, 4020, 164-173.

Markel, A. L., \& Vainer, B. G. (2005). Infrared thermography in diagnosis of breast cancer (review of foreign literature). Ter Arkh, 77(10), 57-61. 
Meeusen, R., \& Borms, J. (1992). Gymnastic injuries. Sports medicine, 13(5), 337-356.

Meola, C., Carlomagno, G. M., \& Giorleo, G. (2004). Using infrared thermography to analyze substrate and adhesive effects in bonded structures. Journal of Adhesion Science and Technology, 18(6), 617-634.

Merla, A., Mattei, P. A., Di Donato, L., \& Romani, G. L. (2010). Thermal imaging of cutaneous temperature modifications in runners during graded exercise. Ann Biomed Eng, 38(1), 158-163.

Mital, M. (2004). Thermal Detection of Embedded Tumors using Infrared Imaging. Unpublished Master's Thesis, Virginia Tech.

Mishin,VP.,Garbuzov. (1951). Results of thermography substances.Biokhimia, 16(5),416-9.

Mohammed, J., Balma-Mena, A., Chakkittakandiyil, A., Matea, F., Pope, 5. (2014). JAMA Dermatol, 150(9):964-9.

Nakayama, T., Ohnuki, Y., \& Kanosue, K. (1981). Fall in skin temperature during exercise observed by thermography. Jpn J Physiol, 31(5), 757-762.

Namdari, S., Scott, K., Milby, A., Baldwin, K., \& Lee, G. C. (2011). Athletic Performance After $\mathrm{ACL}$ Reconstruction in the Women's National Basketball Association. Physician and Sports medicine, 39(1), 36-41.

Negahban, H., Mostafaee, N., Sohani, S. M., \& Mazaheri, M. (2011). Reliability and validity of the Tegner and Marx activity rating scales in Iranian patients with anterior cruciate ligament injury. Disability and Rehabilitation, 33(23-24), 2305-2310.

$\mathrm{Ng}$, E. Y. K. (2009). A review of thermography as promising non-invasive detection modality for breast tumor. International Journal of Thermal Sciences, 48(5), 849-859.

Niu, H., Lui, P., Hu, J., Ting, C., Ying, Y., Lo, Y., et al. (2001). Thermal symmetry of skin temperature: Normative data of normal subjects in Taiwan. Zhonghua Yi Xue Za Zhi, 64, 459-468.

Osorio Cruz, O. H., \& Caballero Bello, E. (2005). Importancia de la termografía infrarroja en el diagnóstico de transformadores de potencia. Retrieved from www.acoeq.com.mx//Ing.Oscar\%20Hugo\%200sorio\%20Cruz-TECSA.pdf

Parisky, Y. R., Sardi, A., Hamm, R., Hughes, K., Esserman, L., Rust, S., et al. (2003). Efficacy of computerized infrared imaging analysis to evaluate mammographically suspicious lesions. AJR Am J Roentgenol, 180(1), 263-269.

Pascoe, D. D. F., Llanos, J., Molloy, J. M., Smith, J. W., \& Kramer, W. A. (2001). Influence of environmental temperature on the calculations of mean skin temperature. Medicine \& Science in Sports \& Exercise, 33(5) Supplement(1), S222.

Paus, V. (1999). El entrenamiento de la fuerza en la rehabilitacion del Ligamento Cruzado Anterior. The strength training in the anterior cruciate ligament rehabilitation., 4(14).

Perez, R., Oerlemans, H. M., Zuurmond, W., \& De Lange, J. (2003). Impairment level SumScore for lower extremity Complex Regional Pain Syndrome type I. Disability and Rehabilitation, 25(17), 984-984.

Petrofsky, J. S., Lohman, E., 3rd, Suh, H. J., Garcia, J., Anders, A., Sutterfield, C., et al. (2006). The effect of aging on conductive heat exchange in the skin at two environmental temperatures. Med Sci Monit, 12(10), CR400-408.

Pichot, C. (2001). Aplicación de la termografía en el dolor lumbar crónico. Revista de la Sociedad Española del Dolor, 8(2), 43-47.

Ping, Z., \& You, F. T. (1993). Correlation study on infrared thermography and nerve root signs in lumbar intervertebral disk herniation patient: a short report. J Manipulative Physiol Ther, 16(3), 150-154.

Piñonosa, S., Sampedro, J.,\& Fernández Cuevas, I. (2012). La termografía como nueva herramienta de evaluación en baloncesto. Estudio piloto realizado a un jugador profesional de la ACB. Cuadernos de psicología del deporte, 12(s1), 51-56. 
Piñonosa, S., Sillero-Quintana, M., Milanovic, L., Coterón, J., \& Sampedro, J. (2013). Thermal evolution of lower limbs during a rehabilitation process after anterior cruciate ligament surgery. Kinesiology (Zagreb, Croatia), 45(1), 121-129.

Pochaczevsky, R. (1987). Thermography in posttraumatic pain. Am J Sports Med, 15(3), 243250.

Potter, N. D. (2006). Complications and treatment during rehabilitation after anterior cruciate ligament reconstruction. Operative Techniques in Sports Medicine, 14(1), 50-58.

Priego Quesada, J., Carpes, F., Bini, R., Salvador Palmer, R., Pérez-Soriano, P., Cibrián Ortiz de Anda, R. (2015). Relationship between skin temperature and muscle activation during incremental cycle exercise. Thermal Biology, 48:28-35.

Reinberg, A. (1975). Circadian changes in the temperature of human beings. Bibliotheca radiologica(6), 128-139.

Reinikainen, L. M., \& Jaakkola, J. J. (2003). Significance of humidity and temperature on skin and upper airway symptoms. Indoor Air, 13(4), 344-352.

Ring. (1990). Quantitative thermal imaging. Clinical physics and physiological measurement, 11 Suppl A, 87-95.

Ring. (2004). The historical development of thermal imaging in medicine. Rheumatology (Oxford), 43(6), 800-802.

Ring. (2006). The historical development of thermometry and thermal imaging in medicine. $J$ Med Eng Technol, 30(4), 192-198.

Ring. (2007). The historical development of temperature measurement in medicine. Infrared Physics \& Technology, 49(3), 297-301.

Ring \& Ammer (2012). Infrared thermal imaging in medicine. Physiol Meas, 33(3), R33-46.

Ring, \& Phillips. (1984). Recent advances in medical thermology. New York: Plenum Press.

Ring, E., \& Ammer, K. (2000). The Technique of Infra red Imaging in Medicine. Thermology International, 10(1), 7-14.

Ring, E. F., Collins, A. J., Bacon, P. A., \& Cosh, J. A. (1974). Quantitation of thermography in arthritis using multi-isothermal analysis. II. Effect of nonsteroidal anti-inflammatory therapy on the thermographic index. Ann Rheum Dis, 33(4), 353-356.

Rochcongar, P., \& Schmitt, M. (1979). Thermographic study of muscular lesions in sport (author's transl). Journal belge de medecine physique et de rehabilitation, 2(4), 335342.

Roehl, K., Becker, S., Fuhrmeister, C., Teuscher, N., Futing, M., \& Heilmann, A. (2009). New, non-invasive thermographic examination of body surface temperature on tetraplegic and paraplegic patients, as a supplement to existing diagnostic measures. Spinal Cord, 47(6), 492-495.

Romanò, C. L., Logoluso, N., Dell'Oro, F., Elia, A., \& Drago, L. (2012). Telethermographic findings after uncomplicated and septic total knee replacement. The Knee, 19(3), 193197.

Rothchild, I., \& Barnes, A. C. (1952). The effects of dosage, and of estrogen, androgen or salicylate administration on the degree of body temperature elevation induced by progesterone. Endocrinology, 50, 485-496.

Roy, R., Boucher, J. P., \& Comtois, A. S. (2013). Comparison of paraspinal cutaneous temperature measurements between subjects with and without chronic low back pain. Journal of Manipulative and Physiological Therapeutics, ;36(1):44-50.

Roy, R., Boucher, J. P., \& Comtois, A. S. (2006). Validity of Infrared Thermal Measurements of Segmental Paraspinal Skin Surface Temperature. Journal of Manipulative and Physiological Therapeutics, 29(2), 150-155.

Sadler, G. R., Ko, C. M., Cohn, J. A., White, M., Weldon, R. N., \& Wu, P. (2007). Breast cancer knowledge, attitudes, and screening behaviors among African American women: the Black cosmetologists promoting health program. BMC Public Health, 7, 57. 
Salisbury, R. S., Parr, G., De Silva, M., Hazleman, B. L., \& Page-Thomas, D. P. (1983). Heat distribution over normal and abnormal joints: thermal pattern and quantification. Ann Rheum Dis, 42(5), 494-499.

Sands, W. A., McNeal, J. R., \& Stone, M. H. (2007). Thermal imaging and Gymnastics injuries: A means of screening and injury identification. Science of Gymnastics Journal, 3(2), 5-12.

Serway, \& Beichner. (2002). Física. Mexico DF: McGraw Hill.

Sham, F. C., Chen, N., \& Long, L. (2008). Surface crack detection by flash thermography on concrete surface. Insight, 50(5), 240-243.

Shamaa, A. A., \& Gohar, H. M. (2002). Clinical assessment of thermography as a diagnostic and prognostic tool in horse practice. Retrieved from www.nbn.at/downloads/dl.php?id=Q01TXzAwNA==\&lang=de -

Shapiro, Y., Pandolf, K. B., Avellini, B. A., Pimental, N. A., \& Goldman, R. F. (1980). Physiological responses of men and women to humid and dry heat. J Appl Physiol, 49(1), 1-8.

Sigalés, B. (2003). Transferencia de calor técnica (Vol. 1). Barcelona: Reverte.

Sillero Quintana, M., Gómez Carmona, P. M., García de la Concepción, M. Á., Fernández Cuevas, I., Piñonosa Cano, S., \& Cordente, C. A. (2010). Application of thermography as injury prevention method and monitoring of the injury recovery in Athletics. Paper presented at the World Congress on Science in Athletics, INEFC Barcelona.

Specchiulli, F., Mastrosimone, N., Laforgia, R., \& Solarino, G. B. (1991). Acute lesions of the lateral ligaments of the ankle. Clinical and radiographic review. Italian journal of orthopaedics and traumatology, 17(2), 261-268.

Staffa E., Bernard, Kubicek, Valchovsky, Vik, Mornstein, Bourek, Staffa R. (2016). Vascular. Retrieved 24-02-2016, from DOI: 1708538116640444.

Steketee, J. (1976). The influence of cosmetics and ointments on the spectral emissivity of skin. Phys Med Biol, 21(6), 920-930.

Stupka, M., \& Krumelovä, M. (2002). Thermograpic imaging of muscle tone changes.

Tang, X., Ding, H., Yuan, Y.-e., \& Wang, Q. (2008). Morphological measurement of localized temperature increase amplitudes in breast infrared thermograms and its clinical application. Biomedical Signal Processing and Control, 3(4), 312-318.

Teske, W., Anastisiadis, A., Lichtinger, T., Schulze Pellengahr, C., Engelhardt, L. V., \& Theodoridis, T. (2010). Rupture of the anterior cruciate ligament. Der Orthopäde, 39(9), 883-900.

Tham, T. C., Silke, B., \& Taylor, S. H. (1990). Comparison of central and peripheral haemodynamic effects of dilevalol and atenolol in essential hypertension. $J$ Hum Hypertens, 4 Suppl 2, 77-83.

Tkacova, M. (2010). The Methodics of Medical Thermography in the Diagnostics of the Human Body Musculoskeletal System. 2010 IEEE 8th international symposium on applied machine intelligence and informatics, 275-277.

Torii, M., Yamasaki, M., Sasaki, T., \& Nakayama, H. (1992). Fall in skin temperature of exercising man. Br J Sports Med, 26(1), 29-32.

Tse, G., \& Puay-Hoon. (2010). Diagnosing breast lesions by fine needle aspiration cytology or core biopsy: which is better? Breast Cancer Research and Treatment, 123(1), 1-8.

Uematsu et al.,, S., Edwin, D. H., Jankel, W. R., Kozikowski, J., \& Trattner, M. (1988a). Quantification of thermal asymmetry. Part 1: Normal values and reproducibility. $J$ Neurosurg, 69(4), 552.

Uematsu et al.,, S., Edwin, D. H., Jankel, W. R., Kozikowski, J., \& Trattner, M. (1988b). Quantification of thermal asymmetry. Part 2: Application in low-back pain and sciatica. J Neurosurg, 69(4), 556.

Usuki, K., Kanekura, T., Aradono, K., \& Kanzaki, T. (1998). Effects of nicotine on peripheral cutaneous blood flow and skin temperature. J Dermatol Sci, 16(3), 173-181. 
Vainer, B. G. (2000). Non-steady-state phenomena inspection through the use of infrared thermography. Quantitative InfraRed Thermography 5,Eurotherm Seminar 64. Retrieved 9-12-2015, from http://qirt.gel.ulaval.ca/dynamique/index.php?idD=45.

Ventura, A. (2010). Synthetic grafts for anterior cruciate ligament rupture: 19-year outcome study. The Knee, 17(2), 108-113.

Vardasca, R. (2008). Symmetry of temperature distribution in the upper and the lower extremities. Thermology International, 18(4), 154.

Viale, M., Martin, O., Muratori, F., Bertezzolo, U., Perez, J., Partemio, C., et al. (2007). Application of on-line infrared thermography in steel making industry. Thermosense XXIX, 6541, H5410-H5410.

Wilmore, J. H., \& Costill, D. L. (2008). Fisiología del esfuerzo y del deporte. Barcelona :: Paidotribo.

Wong, P., \& Hong, Y. (2005). Soccer injuries in the lower extremities. Br J Sports Med, 39(8), 473-482.

Yabroudi, M. A., \& Irrgang, J. J. (2013). Rehabilitation and Return to Play After Anatomic Anterior Cruciate Ligament Reconstruction. Clinics in Sports Medicine, 32(1), 165-175.

Yahara, T., Koga, T., Yoshida, S., Nakagawa, S., Deguchi, H., \& Shirouzu, K. (2003). Relationship between microvessel density and thermographic hot areas in breast cancer. Surgey Today, 33(4), 6.

Yang, K. F. (1988). Study of the state of blood circulation of the extremity using infrared thermography. Zhonghua Wai Ke Za Zhi, 26(5), 276-278, 318.

Youk, J. H., \& Kim, E. K. (2010). Supplementary screening sonography in mammographically dense breast: pros and cons. Korean J Radiol, 11(6), 589-593.

Zadeh, Haddadnia, Ahmadinejad, Baghdad. (2015). Assesing the potential of thermal imaging in recognition of breast cancer. Asian Pac J Cancer Prev, 16(18), 8619-23.

Zaproudina, N. (2012). Methodological aspects of use of Infrared Thermography in healthy individuals and patients with nonspecific musculoskeletal disorders. University of Eastern Finland, Kuopio.

Zaproudina, N., Ming, Z., \& Hanninen, O. O. (2006). Plantar infrared thermography measurements and low back pain intensity. J Manipulative Physiol Ther, 29(3), 219-223.

Zaproudina, N., Varmavuo, V., Airaksinen, O., \& Narhi, M. (2008). Reproducibility of infrared thermography measurements in healthy individuals. Physiol Meas, 29(4), 515-524.

Zontak, A., Sideman, S., Verbitsky, O., \& Beyar, R. (1998b). Dynamic thermography: analysis of hand temperature during exercise. Annals of biomedical engineering, 26(6), 988-993. 
10. APPENDIX 
10. APPENDIX

10.1. DATA COLLECTION INFORMATION

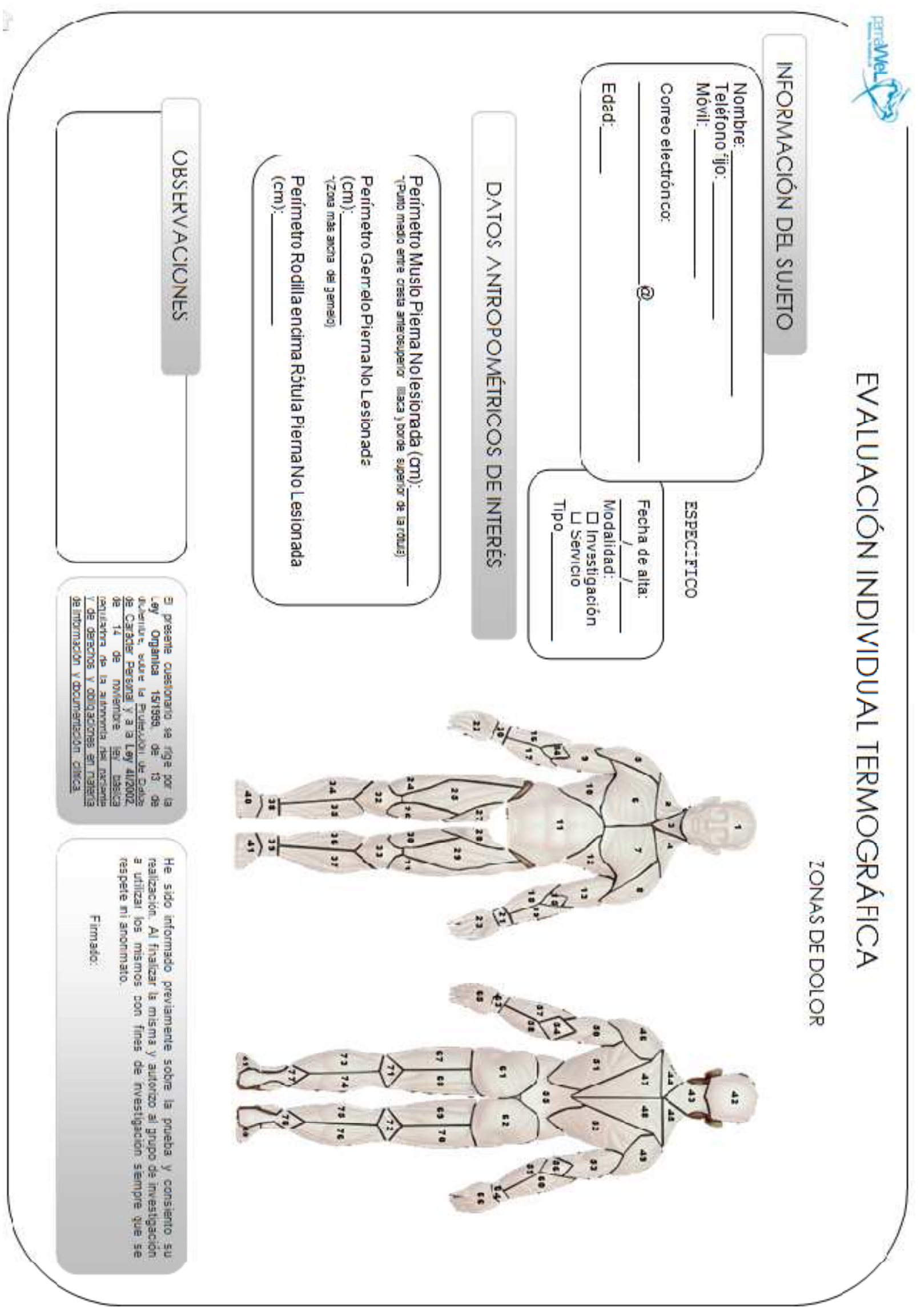


'Rellenar la casilla cuanda la respuesta se a positiva. Uilizar observaciones para cualquier dato de especial imporlancia. "Utimas at hơras
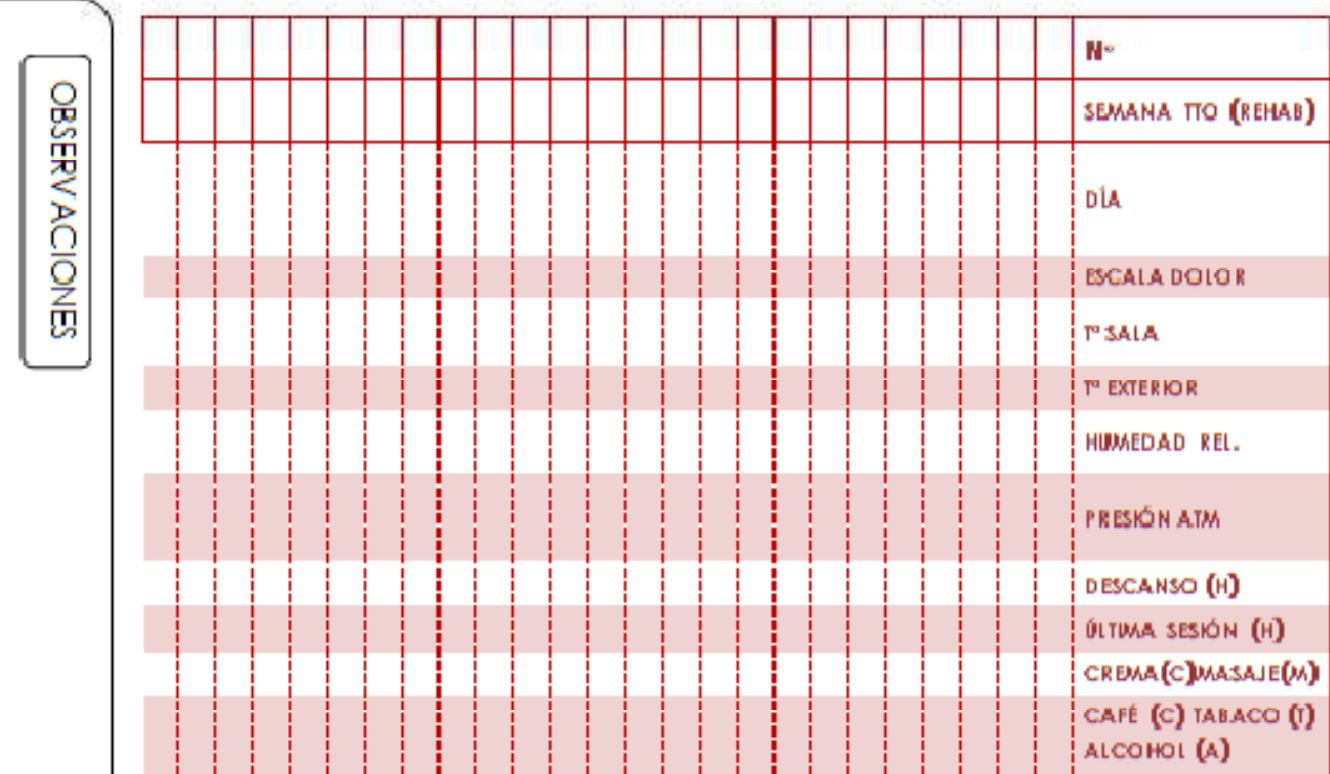

sol

FARMACO

DUСHA

Perimetro Musio

Perimetro Gemelo

Perimero Rodilo

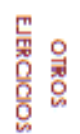

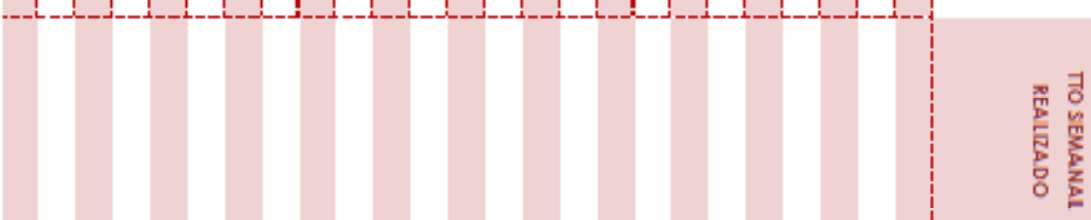

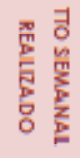

$1+1$

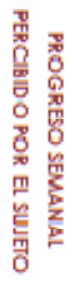

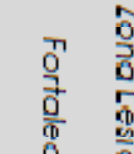

긍 $\frac{0}{3}$.

(⿻)

क궁

웅모

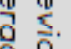

o: 0

$3 \frac{2}{\sigma}$

告

제에

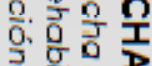

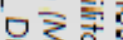

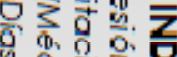

응

का

ํำ

믕ำ

高

(⿻)

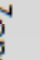

五全兴

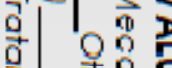

.

五贾

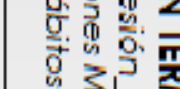

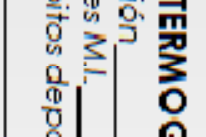

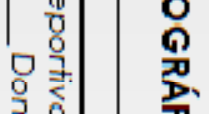

3.

ริ.

离

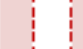
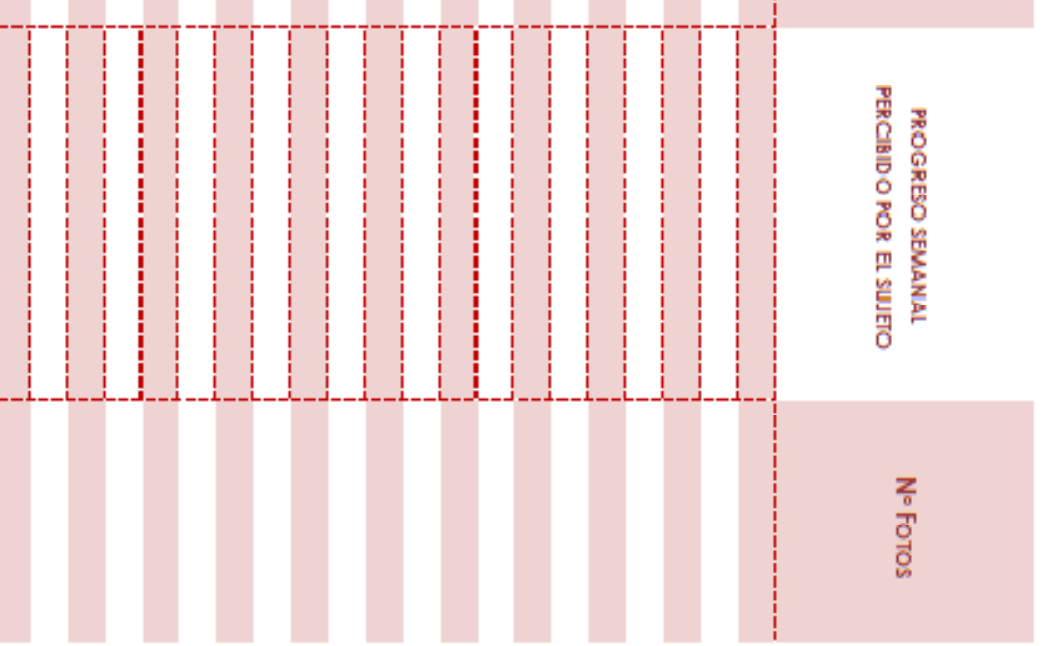
10.2. ETHICS COMMITTEE REPORT OF THE TECHNICAL UNIVERSITY OF MADRID

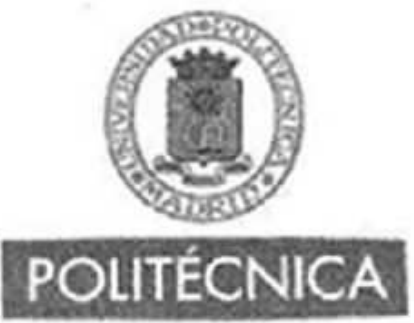

\section{INFORME QUE EMITE EL COMITÉ DE ÉTICA DE LA UNIVERSIDAD POLITÉCNICA DE MADRID}

A petición del Vicerrector de Investigación de la Universidad Politécnica de Madrid, D. Gonzalo León Serrano, de un dictamen sobre los aspectos éticos y de seguridad del proyecto de investigación "La Termografía como medio de detección, prevención y seguimiento de problemas y lesiones derivados de la actividad fisico-deportiva en poblaciones especiales" (THERMOSPEC) cuyo investigador principal es D. Manuel Sillero Quintana del Departamento de Deportes de la Facultad de Ciencias de la Actividad Física y del Deporte (INEF), tras los pertinentes análisis, estudios y consultas, la Comisión emite el siguiente informe:

Dado que por un lado el responsable del proyecto asegura conocer los procesos y protocolos relativos a la protección de datos y por otro lado en dicho proyecto se utilizará una técnica no invasiva (termografia) y todos los sujetos serán previamente informados sobre los objetivos del proyecto firmando un consentimiento informado para su participación en el estudio,

No hay inconveniente en informar favorablemente la propuesta, recomendando el efectivo cumplimiento de los compromisos declarados.

$\mathrm{Y}$ para que asi conste, firmo el presente informe en Madrid a trece de febrero de dos mil nueve.
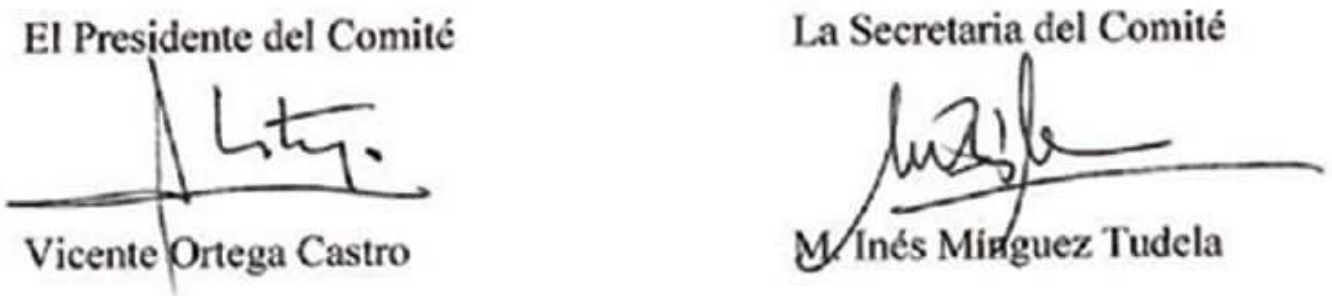
10.3. TRAINING PROTOCOL AFTER THE SIX WEEKS OF REHABILITATION

iM

SaludMadrid
Hospital Clínico San Carlos

Comunidad de Madrid
SERVICIO DE MEDICINA FÍSICA Y REHABILITACIÓN

\section{PROTOCOLO DE REENTRENAMIENTO DEL LCA}

$\rightarrow$ Comenzar a los 2,5 - 3 meses tras la cirugía.

1a SEMANA: Comenzar carrera continua, 5 minutos en días alternos. Terreno llano, sin cuestas, en circuito abierto, no en pista (MARCAR RITMO CON PIERNA MALA).

$2^{\mathrm{a}}$ SEMANA: Carrera continua, 10 minutos en días alternos.

3a SEMANA: Velocidad / cambios de dirección: (CARRERA PREVIA 10 MINUTOS)

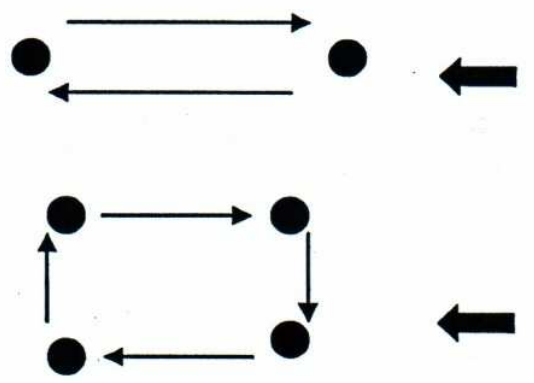

10 repeticiones: las 5 primeras carrera frontal. El resto carrera frontal/ marcha atrás.

Aumentar velocidad según tolerancia.

10 repeticiones: las 5 primeras carrera frontal. El resto carrera frontal- lateralatrás-lateral.

4a SEMANA: Velocidad / cambios de dirección: (CARRERA PREVIA 10 MINUTOS)

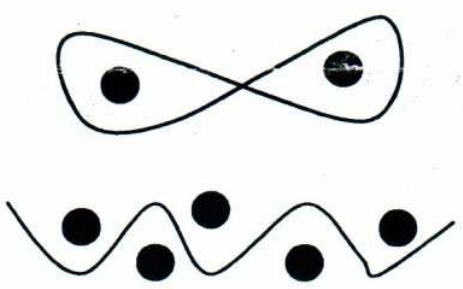

pram

10 repeticiones: Carrera en " 8 ":

primero frontal, después marcha atrás.

10 repeticiones: Carrera en "zig-zag";

primero frontal y después marcha atrás.

$5^{\mathbf{a}}$ y $\mathbf{6}^{\mathrm{a}}$ SEMANAS: Saltos / Multisaltos. (CARRERA PREVIA 10 MINUTOS)

10 repeticiones rodillas al pecho.

$1^{\circ}$ en suelo.

$2^{\circ}$ en colchoneta. Salto de banco lateralmente.

$3^{\circ}$ salto desde una altura.

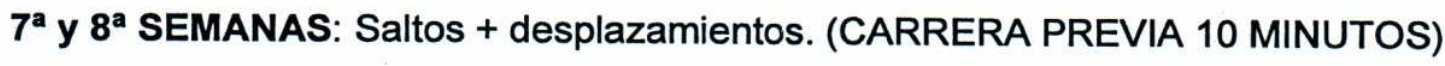

$\left.1^{\circ}\right)$ salto + desplazamiento

$2^{\circ}$ ) carrera + salto + cambios de dirección

$\{10$ repeticiones

\section{TOTAL: 8 SEMANAS}

Observaciones: Si en cualquier momento aparece dolor o inflamación tras los ejercicios, dejar pasar 2 días. Si persiste o aumenta, consultar con médico. Si mejora, no pasar a la siguiente fase manteniendo la previa una semana más y valorar. 